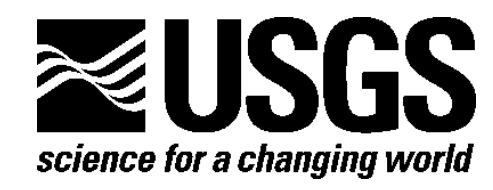

Prepared in cooperation with the Orange County Utilities Department

\title{
Potential for Denitrification near Reclaimed Water Application Sites in Orange County, Florida, 2009
}

By Michael J. Byrne Sr., Richard L. Smith, and Deborah A. Repert

Open File Report 2012-1123

U.S. Department of the Interior

U.S. Geological Survey 


\section{U.S. Department of the Interior \\ KEN SALAZAR, Secretary}

\section{U.S. Geological Survey \\ Marcia K. McNutt, Director}

U.S. Geological Survey, Reston, Virginia 2012

For product and ordering information:

World Wide Web: http://www.usgs.gov/pubprod

Telephone: 1-888-ASK-USGS

For more information on the USGS—-the Federal source for science about the Earth, its natural and living resources, natural hazards, and the environment: World Wide Web: http://www.usgs.gov

Telephone: 1-888-ASK-USGS

Suggested citation:

Byrne, M.J. Sr., Smith, R.L., and Repert, D.A., 2012, Potential For Denitrification near Reclaimed Water

Application Sites in Orange County, Florida, 2009; U.S. Geological Survey Open-File Report 2012-1123, 54 p.

Any use of trade, product, or firm names is for descriptive purposes only and does not imply endorsement by the U.S. Government.

Although this report is in the public domain, permission must be secured from the individual copyright owners to reproduce any copyrighted material contained within this report. 


\section{Acknowledgments}

The authors are grateful to Orange County employee Kim Kunihiro for her logistical support and advice. Coinvestigator Sharon E. Kroening began this project and provided the foundation for this research. Several U.S. Geological Survey researchers, including David Sumner, Leel Knowles, Andy O’Reilly, Rick Spechler, Nick Sepulveda, and Louis Murray, helped design the final test and provided guidance. 


\section{Contents}

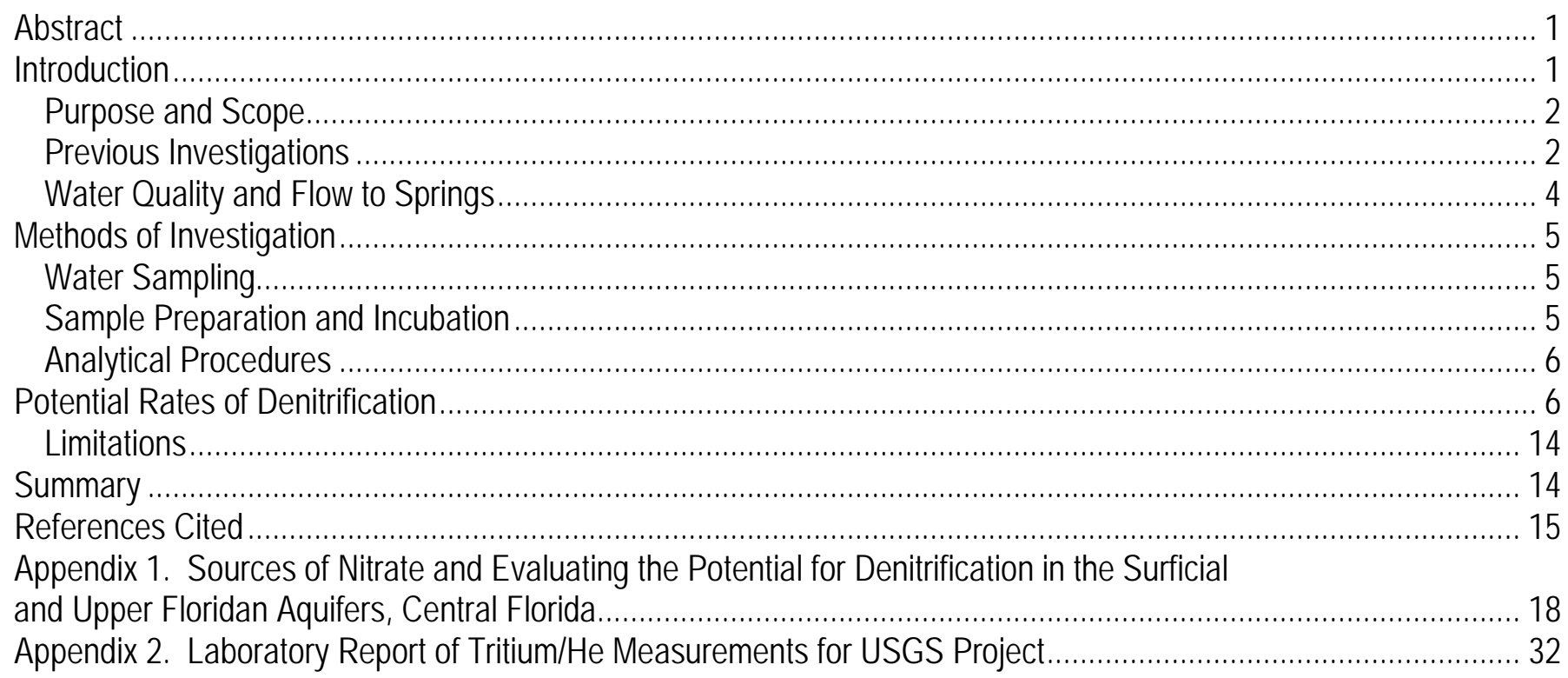

\section{Figures}

Figure 1. Map showing location of study area. 3

Figure 2. Graphs showing time course of nitrous oxide production by well water and spring-water samples during laboratory incubations to measure denitrification potential.

Figure 3. Graphs showing time course of nitrate and nitrite concentration change in well water and spring-water samples during laboratory incubations.

\section{Tables}

Table 1. Site identification and ambient water-quality data Site identification and ambient water-quality data. ............ 8

Table 2. Denitrification rates of water samples based on laboratory analysis. ..................................................... 9 


\section{Conversion Factors}

\begin{tabular}{lcl}
\hline & Multiply & \multicolumn{1}{c}{ Bo obtain } \\
\hline foot (ft) & Length & \\
mile (mi) & 0.3048 & kilometer $(\mathrm{km})$ \\
\hline & 1.609 & \\
\hline acre & Area & square meter $\left(\mathrm{m}^{2}\right)$ \\
acre & 4,047 & hectare (ha) \\
\hline & 0.4047 & \\
\hline gallon (gal) & Volume & liter $(\mathrm{L})$ \\
\hline & 3.785 & \\
\hline million gallons per day (Mgal/d) & Flow rate & cubic meter per second $\left(\mathrm{m}^{3} / \mathrm{s}\right)$ \\
\hline
\end{tabular}

\section{Abbreviations}

$\begin{array}{ll}\text { DOC } & \text { dissolved organic carbon } \\ \text { RIB } & \text { rapid infiltration basin } \\ \text { TN } & \text { total nitrogen } \\ \text { USGS } & \text { U.S. Geological Survey }\end{array}$

Temperature in degrees Celsius $\left({ }^{\circ} \mathrm{C}\right)$ may be converted to degrees Fahrenheit $\left({ }^{\circ} \mathrm{F}\right)$ as follows: ${ }^{\circ} \mathrm{F}=\left(1.8 x^{\circ} \mathrm{C}\right)+32$

Nitrate $\mathrm{mg} / \mathrm{L}$ as $\mathrm{N}$ may be converted to Nitrate $\mathrm{mg} / \mathrm{L}$ as follows: Nitrate $\mathrm{mg} / \mathrm{L}=$ Nitrate $\mathrm{mg} / \mathrm{L}$ as $\mathrm{N} \times 4.43$ 


\title{
Potential for Denitrification near Reclaimed Water Application Sites in Orange County, Florida, 2009
}

\author{
By Michael J. Byrne Sr., Richard L. Smith, and Deborah A. Repert
}

\begin{abstract}
The potential for denitrification was tested in water samples from four Upper Floridan aquifer wells near a reclaimed water application site, in west Orange County Florida, and two adjacent springs. Results of the study indicate that denitrifying bacteria are present in the groundwater and spring water samples, and that these bacteria can readily denitrify the waters when suitable geochemical conditions exist. The acetylene block technique was used to assess nitrous oxide in the samples that was produced by denitrification. The laboratory incubation experiment consisted of four different treatments to each of the six samples: (1) ambient water (no added nitrate or glucose), (2) ambient water amended with 1.4 milligrams per liter (mg/L) nitrate as nitrogen $(\mathrm{N})$, (3) ambient water amended with $5.0 \mathrm{mg} / \mathrm{L}$ nitrate as $\mathrm{N}$, and (4) ambient water amended with $5.0 \mathrm{mg} / \mathrm{L}$ nitrate as $\mathrm{N}$ and $10 \mathrm{mg} / \mathrm{L}$ glucose as $\mathrm{C}_{6} \mathrm{H}_{12} \mathrm{O}_{6}$. A companion set of incubations using treatment 2 tracked changes in nitrate and nitrite concentration with time. The rate of denitrification in treatment 2 ranged from 0.059 to 0.124 milligram per liter per day nitrogen $[(\mathrm{mg} / \mathrm{L}) / \mathrm{d} \mathrm{N}]$ and in treatment 3 ranged from 0.071 to $0.226(\mathrm{mg} / \mathrm{L}) / \mathrm{d} \mathrm{N}$. At all of the sampling sites, treatment 4 yielded denitrification rates at least an order of magnitude greater than those measured for the other treatments; rates ranged from 2.3 to $4.4(\mathrm{mg} / \mathrm{L}) / \mathrm{d}$ N. The electron donor supply, dissolved organic carbon, in the groundwater and springwater is sufficient to remove at least 1.1-1.4 mg/L nitrate as $\mathrm{N}$ in 20 to 30 days, as indicated by nitrous oxide production rates under ambient conditions (treatment 1). The even higher nitrate removal observed with addition of supplemental carbon in treatment 4 suggests that carbon is a limiting nutrient in this reaction. Denitrifying activity might explain the low ambient nitrate concentrations in the Upper Floridan aquifer in this area.
\end{abstract}

\section{Introduction}

Springs in central Florida are threatened by elevated concentrations of nitrate, which lead to algal blooms, fish kills, and oxygen depletion (Walsh and others, 2009). The sources of the nitrate include fertilizer, manure, and septic waste, all of which are carried by rainfall into the Upper Floridan aquifer through natural diffuse downward leakage as well as numerous drainage wells, and karstic features such as sinkholes (Katz and others, 1999). The nitrate-rich groundwater then enters the springs through artesian groundwater discharge. Rapid infiltration basins (RIBs) are shallow basins established to dispose of applied, nitrate-containing reclaimed water and additionally to recharge the Upper Floridan aquifer (Adamski and German, 2003). RIBs initially recharge the surficial aquifer that overlies the Upper Floridan aquifer, then most of the water in the surficial aquifer eventually flows downward to the Upper Floridan aquifer in this area (Adamski and German, 2003). 
Springs have also been affected by groundwater withdrawals. Groundwater consumption in Orange County, Florida, which is predominantly from the Upper Floridan aquifer, has increased from 87 million gallons per day (Mgal/d) in 1965 to 267 Mgal/d in 2005 (Marella, 2009). Increased groundwater consumption has contributed to decreased water levels in the Upper Floridan aquifer and decreased discharge to the springs in Orange County (Adamski and German, 2003).

Nitrate concentrations in the springs are elevated above background concentrations of 0.2 milligram per liter (mg/L) nitrate as nitrogen (N) (Walsh and others, 2009). Nitrate can be naturally reduced to an inert nitrogen gas by a bacterial process called denitrification, which can serve as a remediation mechanism if the appropriate conditions (a suitable electron supply, such as organic carbon, and anoxia) are present:

$$
\mathrm{NO}_{3}{ }^{-} \rightarrow \mathrm{NO}_{2}^{-} \rightarrow \mathrm{NO}+\mathrm{N}_{2} \mathrm{O} \rightarrow \mathrm{N}_{2} \text { (g) }
$$

The process begins with nitrate and the end product of denitrification is non-reactive nitrogen gas (Smith and Duff, 1988). An understanding of the degree to which denitrification occurs, or the "rate of denitrification," in the Upper Floridan aquifer is needed to predict nitrate transport to the springs and the potential amount of nitrate removed within the transport interval.

In 2004, the U.S. Geological Survey (USGS), in cooperation with the Orange County Utilities Department, initiated a study to determine: (1) the source of the nitrate in the Upper Floridan aquifer beneath a RIB site located in west Orange County, Florida (fig. 1); (2) whether denitrification occurs within the aquifer; (3) the age (time since recharge) of the water in the aquifer in this area; and (4) an estimate of the rate of denitrification in the Upper Floridan aquifer. The first two objectives were addressed by Kroening (2007; app. 1). The third objective was addressed by Schlosser and others (2008; app. 2). The final objective of the study is addressed in this report. Estimates of denitrification rates of water from selected springs, in addition to the Upper Floridan aquifer, also are included in this publication.

\section{Purpose and Scope}

The purpose of this report is to describe potential rates of denitrification in water samples from the Upper Floridan aquifer, Wekiwa Springs, and Rock Springs in west Orange County, Florida (fig. 1). In addition, this report incorporates findings from the previous reports completed as part of the study to provide the reader with a single report that addresses all of the study objectives. The "potential” rate of denitrification is defined as the capacity of denitrifying bacteria present in the water to reduce nitrate concentrations when certain optimal conditions exist, (presence of denitrifying bacteria, ample supply of carbon to act as an electron donor source, and reducing conditions related to a low concentration of dissolved oxygen) and does not necessarily reflect what is occurring in the aquifer under ambient conditions. The potential rate of denitrification was calculated as the rate of nitrate reduction to nitrous oxide within water samples using the acetylene block technique in short-term laboratory incubations (Balderston and others, 1976; Yoshinari and others, 1977). For the current effort, a total of six water quality samples were collected at six sites (four groundwater wells, two springs) in late 2009.

\section{Previous Investigations}

Sumner and Bradner (1996) described the fate and transport of nutrients within the surficial aquifer beneath a rapid infiltration basin along the Lake Wales Ridge in Orange County. Removal of nitrogen by denitrification from the percolating reclaimed water was minimal within the surficial aquifer in the immediate vicinity of the basin, probably because of the lack of reducing conditions and a relative 


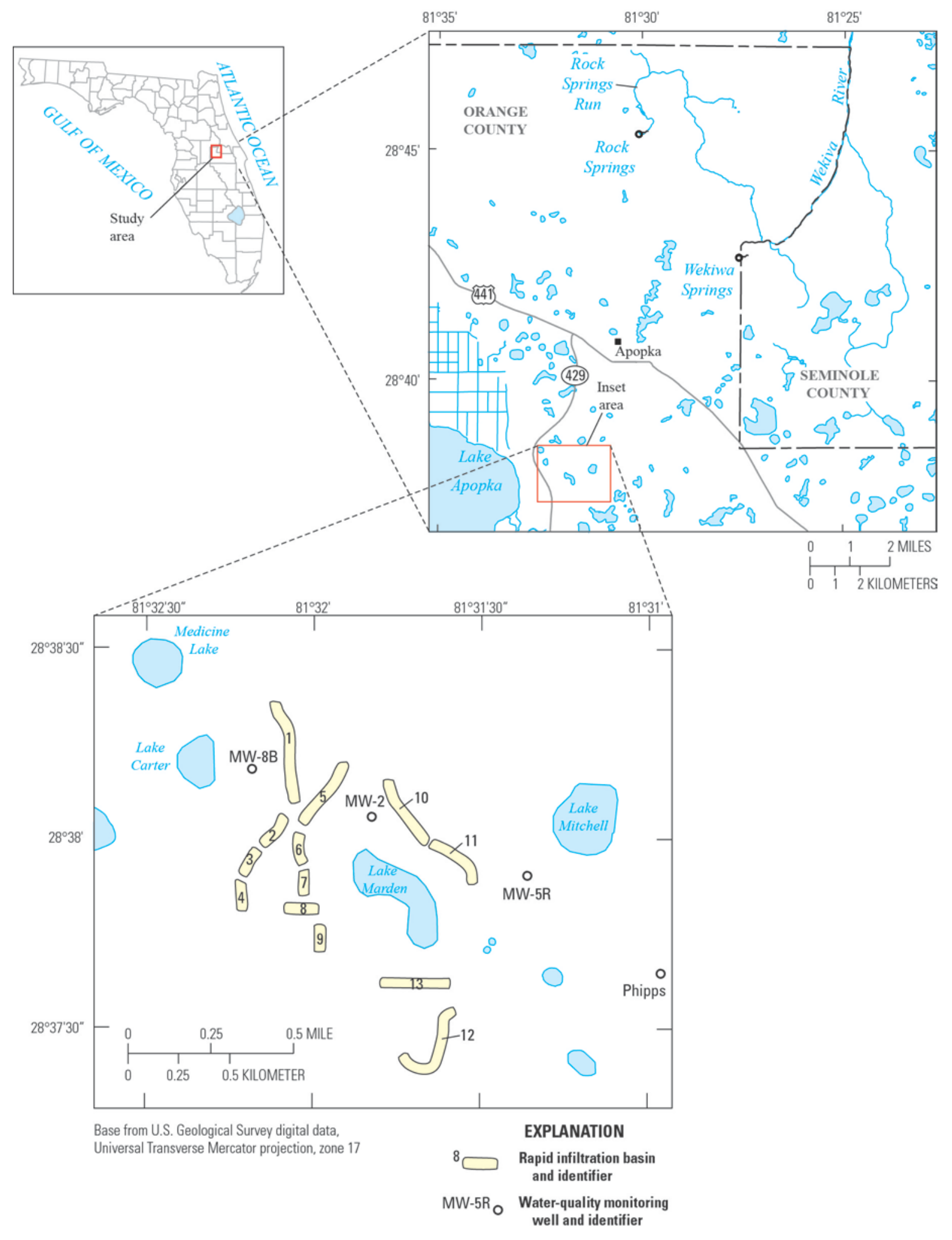

Figure 1. Map showing location of study area. 
paucity of organic carbon substrates. They also noted that phosphorus concentrations were decreased by about 90 percent from concentrations in applied reclaimed water after moving through the upper 15 feet (ft) of the soil profile. This most likely was a result of adsorption onto abundant iron and aluminum hydrous oxyhydroxide coatings on sand grains. A number of models have been developed that describe the northeasterly groundwater flow in the Upper Floridan aquifer in Orange County and predict the areas of aquifer recharge (Murray and Halford, 1996; O’Reilly, 1998; Sepulveda, 2002). Katz and others (1999) used nutrients, isotopes, and major ions to study the spring water in the Suwannee River Basin and found that (1) the age of the spring water was greater than 20 years, (2) nitrate contamination was positively correlated with volume of fertilizer use, and (3) nitrate and dissolved oxygen concentrations in groundwater were positively correlated. Toth and Fortich (2002) also described how nitrate contamination in Rock Springs and Wekiwa Springs was related to fertilizer use in those areas. Walsh and others (2009) found that nitrate contamination had decreased in Rock Springs and Wekiwa Springs by 2007, but was increasing in other springs.

Denitrification in groundwater can be quantified or inferred using several different techniques. Smith and Duff (1988) used the acetylene block technique to determine rates of denitrification in an unconfined sand and gravel aquifer, and discovered that available carbon limited the reaction. Katz and Böhlke (2000) used isotopic signatures of nitrogen to identify denitrification in a carbonate aquifer in the Suwannee River Basin. Kroening (2007; app. 1) found excess nitrogen gas, the end product of denitrification, in the Upper Floridan aquifer beneath the RIBs site that is the focus of this report, and used nitrogen isotopes to identify fertilizer as the source of the nitrate. Nitrogen-15-enriched nitrate also has been injected into groundwater during natural gradient tracer tests to quantify denitrification in situ (Smith and others, 2004).

\section{Water Quality and Flow to Springs}

Historical and recent groundwater quality, as well as estimates of how fast groundwater moves from the RIBs to nearby springs, are presented in this section. The Orange County Northwest Water Reclamation Facility RIBs are located near the west border of Orange County, Florida, more than 7 miles (mi) from Wekiwa Springs and Rock Springs (fig. 1). These RIBs were constructed in 1987, and have a treatment capacity of 7.5 Mgal/d (Morrell and others, 2002). Tertiary wastewater treatment before application consists of grit removal, activated sludge aeration, sand filtration, and disinfection using chlorine.

Although nitrate and dissolved oxygen concentrations are relatively high in the surficial aquifer, indicating potential water-quality degradation beneath the RIBs, results from Kroening (2007) indicate that these effects do not extend to the Upper Floridan aquifer. Nitrate and dissolved-oxygen levels in the surficial aquifer beneath the RIBs were 1.20 to $6.30 \mathrm{mg} / \mathrm{L}$ nitrate as $\mathrm{N}$ and 1.5 to $8.4 \mathrm{mg} / \mathrm{L}$ as $\mathrm{O}_{2}$, respectively (Kroening, 2007; app. 1). Water in the Upper Floridan aquifer beneath the RIBs is suboxic (0.1-0.2 mg/L as $\left.\mathrm{O}_{2}\right)$, and the nitrate concentration is considered to be at background levels (less than $0.2 \mathrm{mg} / \mathrm{L}$ nitrate as N; Kroening, 2007, app I). Dissolved oxygen concentrations are low in Wekiwa Springs (0.40 mg/L as $\mathrm{O}_{2}$ ) and in Rock Springs (1.38 mg/L as $\left.\mathrm{O}_{2}\right)$ (Walsh and others, 2009).

In 1961, the nitrate concentration in Wekiwa Springs was $0.61 \mathrm{mg} / \mathrm{L}$ as $\mathrm{N}$ (Toth and Fortich, 2002); however nitrate concentrations in 2009 in Wekiwa Springs (1.12 mg/L as N) and Rock Springs (1.38 mg/L as $\mathrm{N}$ ) were elevated above the background concentration of $0.2 \mathrm{mg} / \mathrm{L}$ as $\mathrm{N}$ (Walsh and others, 2009). A peak nitrate concentration (2.0 mg/L as N) was measured in Wekiwa Springs in 1995; values have since declined (Toth and Fortich, 2002; Walsh and others, 2009). The declining trend appears to be related to a decrease in citrus acreage, which peaked at 65,000 acres in 1968, dropped substantially to 45,000 acres in 1984 following a hard freeze, and declined further to 10,000 acres by 
2001 (Toth and Fortich, 2002). Toth and Fortich (2002) used isotope data to determine that (1) the source of nitrate was fertilizer and animal waste at Wekiwa Springs, and fertilizer at Rock Springs, and (2) the mean age of the water since recharge to the Upper Floridan aquifer at both springs was approximately 17 years.

Groundwater age and time of travel from the RIBs to the springs were estimated from a groundwater flow model and groundwater age-dating and geochemical methods. Model projections, based on particle tracking (MODPATH 4.2) simulations using a calibrated groundwater flow model of the area (O’Reilly, 1998), indicate that it takes more than 100 years for the water in the Upper Floridan aquifer beneath the RIBs to reach Wekiwa Springs (Nicasio Sepulveda, U.S. Geological Survey, oral commun., 2011). Based on isotopic tritium/helium-3 analysis of replicate samples from one well (MW-2), the water currently in the Upper Floridan aquifer beneath the RIBs is estimated to have entered the aquifer 19 years before present (Schlosser and others, 2008; app. 2). Boron, an element used in detergent, was elevated in the RIBs water, but there were only trace levels in the Upper Floridan aquifer. Kroening (2007; app. 1) suggested the Upper Floridan aquifer beneath the RIBs does not contain water from the RIBs based on the low concentration of boron present. Based on analysis of nitrogen and argon gases in groundwater, Kroening (2007; app. 1) inferred that excess nitrogen gas exists in the Upper Floridan aquifer. The excess dissolved nitrogen gas (1-5 mg/L as $\mathrm{N})$, above the naturally occurring concentration in water at the time of infiltration, was attributed to denitrification. Based on the age of the water in the aquifer and the amount of excess nitrogen gas, a rate of denitrification of $5 \times 10^{-4} \mathrm{mg} / \mathrm{L}$ as $\mathrm{N}$ per day was estimated for this process. Nitrogen isotopic analyses of the excess nitrogen $\left(\mathrm{N}_{2}\right)$ indicated that the source of the nitrogen in the Upper Floridan aquifer was fertilizer, probably from the orange groves that occupied the site prior to the establishment of the RIBs (Kroening, 2007; app. 1).

\section{Methods of Investigation}

The potential rate of denitrification of water in the Upper Floridan aquifer and Wekiwa and Rock Springs was assessed using laboratory incubations. Sample collection and analysis were made in accordance with standard USGS protocols. Further details on the method are provided in Smith and others (2004).

\section{Water Sampling}

Water samples were collected on November 9 and 30, 2009, from four Upper Floridan aquifer wells (MW-8B, MW-5R, MW-2, and Phipps) located on the RIBs property (fig.1), and two nearby springs, Wekiwa Springs and Rock Springs (fig. 1). Groundwater samples were collected by lowering a submersible pump into the open-hole interval of each well and near the main boil of both springs, and pumping at 2.5 liters per minute ( $\mathrm{L} / \mathrm{min}$.) until the field readings of specific conductance, $\mathrm{pH}$, dissolved oxygen, and temperature stabilized. A total of 4 liters $(\mathrm{L})$ of water was collected from each site using sterile pump tubing, and was stored in 1-L amber glass bottles that had previously been baked at $500^{\circ} \mathrm{C}$. The bottles were flushed with 3 to $5 \mathrm{~L}$ of sampled water, filled completely, and capped to avoid an air space. The four bottles from the six sites were then sealed, placed on ice, and shipped overnight to the USGS laboratory in Boulder, Colorado for testing the next day.

\section{Sample Preparation and Incubation}

For each of the six samples, one 1-L bottle was filtered and preserved for nitrate, nitrite, ammonium, dissolved organic carbon (DOC) and total dissolved nitrogen (TN) analyses (Savoie and 
others, 1998). A second 1-L bottle of unfiltered water for each sample was placed immediately into an anaerobic glovebox. In the glovebox, the water was dispensed into triplicate 60-milliliter $(\mathrm{mL})$ serum bottles for each of four treatments to assess denitrification potential. The bottles were stoppered and flushed with helium to replace the glovebox gas (a mixture of nitrogen, hydrogen, and carbon dioxide gases). Anoxic, stock solutions of $250 \mathrm{mg} / \mathrm{L} \mathrm{NaNO}_{3}$ as $\mathrm{N}$ and $500 \mathrm{mg} / \mathrm{L}$ glucose as $\mathrm{C}_{6} \mathrm{H}_{12} \mathrm{O}_{6}$, were then added, as appropriate, to prepare the following treatments: (1) ambient (no added nitrate or glucose), (2) amended with $1.4 \mathrm{mg} / \mathrm{L}$ nitrate as $\mathrm{N}$, (3) amended with $5 \mathrm{mg} / \mathrm{L}$ nitrate as $\mathrm{N}$, and (4) amended with $5 \mathrm{mg} / \mathrm{L}$ nitrate as $\mathrm{N}$ and $10 \mathrm{mg} / \mathrm{L}$ glucose as $\mathrm{C}_{6} \mathrm{H}_{12} \mathrm{O}_{6}$. The glucose plus nitrate addition was included to serve as a positive control to confirm that proper conditions existed for denitrification to occur. Oxygenfree acetylene gas was then added to the headspace of each bottle. Acetylene blocks the reduction of nitrous oxide (an intermediate in the denitrification pathway) to nitrogen gas. Accordingly, in the presence of acetylene, nitrous oxide production over time is used to quantify rates of denitrification. Rates are designated as "potential” denitrification when in situ conditions are altered, such as by adding nitrate and (or) glucose. After the addition of acetylene, the sample bottles were placed on a rotator, set to 4 revolutions per minute, and incubated at room temperature $\left(22^{\circ} \mathrm{C}\right)$. The bottles were analyzed for nitrous oxide concentration in the headspace after 1 hour, at daily intervals for 10 days, and (thereafter) once every few days for 1 to 2 months. At the end of the experiment, water samples were removed by syringe from the serum bottles, filtered, and preserved for nitrate, nitrite, ammonium, and DOC/TN analysis.

Nitrate/nitrite concentrations also were monitored over time in a separate, companion set of incubation bottles as a control for the experiment to measure denitrification without the acetylene block. These were triplicate, 100 -mL unfiltered water samples in serum bottles to which nitrate was added to obtain a concentration of $1.4 \mathrm{mg} / \mathrm{L}$ as $\mathrm{N}$. The bottles were flushed with helium to replace the glovebox gas, but no acetylene was added. This second set of bottles was rotated at room temperature, and water samples were removed by syringe and filtered and preserved for nitrate and nitrite analysis each time a nitrous oxide measurement was made in the headspace of the acetylene-amended bottles. At the end of the experiment, water samples were removed from the companion bottle set and filtered and preserved for nitrate, nitrite, ammonium, and DOC/TN analyses.

\section{Analytical Procedures}

Nitrous oxide production was measured using an HNU gas chromatograph equipped with an electron capture detector. Concentrations were calibrated using authentic standard gas mixtures. Nitrate and nitrite were analyzed using a Dionex Model DX500 ion chromatograph with an AS4A-SC 4-millimeter (mm) analytical column, sodium carbonate/bicarbonate mobile phase, and conductivity detection. Ammonium was measured using a Dionex Model DX300 ion chromatograph with a CS12A 4-mm analytical column, a gradient mobile phase of 5- to 25-mN (millinormal) sulfuric acid, and conductivity detection. Dissolved organic carbon and total dissolved nitrogen were analyzed simultaneously on a Shimadzu combined TOC-VCSN and TNM-1 analyzer with high temperature combustion and chemiluminiscent detection. Alkalinity was measured using a Radiometer Model ABU93 auto-titrator.

\section{Potential Rates of Denitrification}

The potential rate of denitrification was calculated as the rate of nitrate reduction to nitrous oxide within water samples, quantified by nitrous oxide production. All samples tested exhibited potential denitrifying activity, as evidenced by the accumulation of nitrous oxide in the presence of 
acetylene (fig. 2). All groundwater samples except the Phipps Well sample required an addition of nitrate or nitrate plus glucose for denitrification, whereas both springwater samples demonstrated denitrifying activity under all conditions tested. Most of the incubations showed an initial 1 to 2 day lag period, followed by a period of linear (steady) nitrous oxide production, and a subsequent tapering off in production with the exhaustion of the nitrate pool. Estimates of rates of denitrification were determined using linear regression over the initial portion of the nitrous oxide production curve (fig. 2). In three of the four wells, MW-2, MW-5R, and MW-8B, the ambient nitrate concentrations were too low (below $0.04 \mathrm{mg} / \mathrm{L}$ as $\mathrm{N}$ ) to establish a denitrification rate using treatment 1 . In the Phipps Well sample, the ambient nitrate concentration was $0.13 \mathrm{mg} / \mathrm{L}$ as $\mathrm{N}$ (table 1 and the denitrification rate for treatment 1 was 0.050 milligram per liter nitrogen per day $[(\mathrm{mg} / \mathrm{L}) / \mathrm{d}] \mathrm{N}$ (table 1$)$. When nitrate was added for treatments 2 and 3, the denitrification rate doubled (table 2). Wekiwa Springs water had an ambient nitrate concentration of $1.12 \mathrm{mg} / \mathrm{L}$ as $\mathrm{N}$ and the denitrification rate for treatment 1 was $0.072(\mathrm{mg} / \mathrm{L}) / \mathrm{d} \mathrm{N}$; treatments 2 and 3 yielded higher denitrification rates. Rock Springs water had an ambient nitrate concentration of $1.38 \mathrm{mg} / \mathrm{L}$ as $\mathrm{N}$ and a denitrification rate of $0.071(\mathrm{mg} / \mathrm{L}) / \mathrm{d} \mathrm{N}$ for treatment 1; treatments 2 and 3 yielded higher denitrification rates. Water from well MW-2 had a denitrification rate of $0.059(\mathrm{mg} / \mathrm{L}) / \mathrm{d} \mathrm{N}$ for treatment 2 with a higher rate of $0.087(\mathrm{mg} / \mathrm{L}) / \mathrm{d} \mathrm{N}$ for treatment 3 (table 2). At all of the sampling sites, treatment 4 yielded denitrification rates at least an order of magnitude greater than those measured for the other treatments; rates ranged from 2.3 to $4.4(\mathrm{mg} / \mathrm{L}) / \mathrm{d} \mathrm{N}$ as shown in figure 2 and table 2.

At four of the six sites, the calculated denitrification rate was similar in treatments 2 and 3 (fig. 2). This finding may indicate that when nitrate exceeds about $1.4 \mathrm{mg} / \mathrm{L}$ as $\mathrm{N}$, the denitrification rate is not limited by available nitrate. Rock Springs deviated the most; the denitrification rate in this sample for treatment 3 was 2.4 times as high as treatment 2 (table 2, fig. 2). For all the samples, the order of magnitude increase in the denitrification rate produced by the addition of carbon in the form of glucose (treatment 4) indicates that carbon availability may be the primary control on nitrous oxide production. Ambient dissolved organic carbon (1-3 mg/L), which is the electron donor supply in the groundwater and spring water, is sufficiently abundant to remove at least 1.1-1.4 mg/L nitrate as $\mathrm{N}$ in 20 to 30 days, even in situations where the background nitrate concentration in groundwater is low. The rate of nitrate consumption was determined at all sites for the companion set of sample bottles that were amended with $1.4 \mathrm{mg} / \mathrm{L}$ nitrate as $\mathrm{N}$ using the linear section of the nitrate consumption curves in figure 3 (table 2). At most sites, the rate of nitrate consumption exceeded the rate of nitrous oxide production; this difference is primarily attributable to nitrite production. One exception, however, was the sample from Rock Springs, for which the rate of nitrate consumption for treatment 3 and nitrous oxide production were comparable $[0.226(\mathrm{mg} / \mathrm{L}) / \mathrm{d} \mathrm{N}$ and $-0.218(\mathrm{mg} / \mathrm{L}) / \mathrm{d} \mathrm{N}$, respectively, table 2]. The slowest rate of nitrate consumption, $0.09(\mathrm{mg} / \mathrm{L}) / \mathrm{d} \mathrm{N}$, occurred in the groundwater sample from well MW-5R, and the fastest, 0.27 (mg/L)/d N, occurred in the Wekiwa Springs sample. Consumption rates for all other sites ranged between 0.17 and $0.23(\mathrm{mg} / \mathrm{L}) / \mathrm{d} \mathrm{N}$.

Using the ambient nitrous oxide production rates, the number of days required to consume available nitrate was calculated for the three sites that had above-background nitrate concentrations. The available nitrate would be consumed in 15, 2.6, and 20 days at Wekiwa Springs, Phipps Well, and Rock Springs, respectively, assuming that the rates remain constant as nitrate concentrations decrease.

In a separate laboratory control sample experiment, bottles, without an acetylene block and amended with $1.4 \mathrm{mg} / \mathrm{L}$ nitrate as $\mathrm{N}$ were also measured over several weeks. In these samples all available nitrate was removed through denitrification in 4 to 6 days, with an initial lag, leaving only background concentrations of $0.04 \mathrm{mg} / \mathrm{L}$ nitrate as $\mathrm{N}$. 
Table 1. Site identification and ambient water-quality data Site identification and ambient water-quality data.

[mg/L, milligrams per liter; mg/L as N, milligrams per liter as nitrogen]

\begin{tabular}{|c|c|c|c|c|c|c|c|c|c|c|}
\hline Site name & Well number & $\begin{array}{l}\text { Date of } \\
\text { sample }\end{array}$ & $\begin{array}{c}\text { Well } \\
\text { depth, in } \\
\text { feet } \\
\text { below } \\
\text { land } \\
\text { surface }\end{array}$ & $\begin{array}{c}\text { Water } \\
\text { temperature, } \\
\text { in }{ }^{\circ} \mathrm{C}\end{array}$ & $\begin{array}{c}\mathrm{pH}, \text { in } \\
\text { standard } \\
\text { units }\end{array}$ & $\begin{array}{c}\text { Specific } \\
\text { conduc- } \\
\text { tance, in } \\
\mu S / c m\end{array}$ & $\begin{array}{l}\text { Dissolved } \\
\text { oxygen, } \\
\text { in mg/L }\end{array}$ & $\begin{array}{c}\text { Nitrate, in } \\
\mathrm{mg} / \mathrm{L} \\
\text { as N }\end{array}$ & $\begin{array}{c}\text { Totalb } \\
\text { Nitrogen, in } \\
\text { mg/L as } N\end{array}$ & $\begin{array}{c}\text { Dissolved } \\
\text { Organic } \\
\text { Carbon, in } \\
\text { mg/L as C }\end{array}$ \\
\hline MW-2 & 283803081314901 & 11/09/09 & 160 & 25.7 & 7.46 & 504 & 0.23 & 0.042 & 0.436 & 2.229 \\
\hline MW-5R & 283754081312101 & $11 / 09 / 09$ & 165 & 25.7 & 7.84 & 333 & 0.16 & 0.020 & 0.076 & 1.064 \\
\hline MW-8B & 283809081321001 & 11/09/09 & 170 & 26.0 & 7.95 & 278 & 0.32 & 0.032 & 0.116 & 1.263 \\
\hline Phipps Well & 283738081305801 & 11/30/09 & 165 & 24.1 & 7.53 & 308 & NA & 0.129 & 0.197 & 1.088 \\
\hline Rock Springs & 2234610 & 11/30/09 & --- & 23.4 & 7.61 & 269 & $1.38^{\mathrm{a}}$ & 1.385 & 1.521 & 0.673 \\
\hline $\begin{array}{l}\text { Wekiwa } \\
\text { Springs }\end{array}$ & 2234600 & $11 / 30 / 09$ & --- & 24.0 & 7.30 & 357 & $0.40^{\mathrm{a}}$ & 1.117 & 1.254 & 1.129 \\
\hline
\end{tabular}

${ }^{a}$ Median concentration from Walsh and others (2009).

b Difference between Total Nitrogen and Nitrate is predominately ammonia 
Table 2. Denitrification rates of water samples based on laboratory analysis.

[(mg/L)/d N, milligrams nitrogen per liter per day; mg/L nitrate, milligrams nitrate-nitrogen per liter; NA, not applicable]

\begin{tabular}{|c|c|c|c|c|c|c|}
\hline Site name & Date & $\begin{array}{c}\text { 1st treatment } \\
\text { ambient } \\
\text { denitrification rate, } \\
\text { in }(\mathrm{mg} / \mathrm{L}) / \mathrm{d} \mathrm{N}\end{array}$ & $\begin{array}{l}\text { 2nd treatment } \\
\text { ambient sample } \\
\text { amended with } \\
1.4 \mathrm{mg} / \mathrm{L} \text { nitrate } \\
\text { denitrification rate, } \\
\text { in }(\mathrm{mg} / \mathrm{L}) / \mathrm{d} \mathrm{N}\end{array}$ & $\begin{array}{l}\text { 3rd treatment } \\
\text { ambient sample } \\
\text { amended with } \\
5.0 \mathrm{mg} / \mathrm{L} \text { nitrate } \\
\text { denitrification rate, } \\
\text { in }(\mathrm{mg} / \mathrm{L}) / \mathrm{d} \mathrm{N}\end{array}$ & $\begin{array}{c}\text { 4th treatment } \\
\text { ambient sample } \\
\text { amended with } \\
5.0 \mathrm{mg} / \mathrm{L} \text { nitrate and } \\
10 \mathrm{mg} / \mathrm{L} \text { glucose } \\
\text { denitrification rate, } \\
\text { in }(\mathrm{mg} / \mathrm{L}) / \mathrm{d} \mathrm{N}\end{array}$ & $\begin{array}{l}\text { Nitrate consumption } \\
\text { rate sample } \\
\text { amended with } \\
1.4 \mathrm{mg} / \mathrm{L} \text { nitrate, in } \\
\text { (mg/L)/d N }\end{array}$ \\
\hline MW-2 & $11 / 10 / 09$ & NA & 0.059 & 0.087 & 2.3 & -0.227 \\
\hline MW-5R & $11 / 10 / 09$ & NA & 0.083 & 0.071 & 4.0 & -0.090 \\
\hline MW-8B & $12 / 15 / 08$ & NA & 0.120 & NA & NA & NA \\
\hline MW-8B & $11 / 10 / 09$ & NA & 0.118 & 0.127 & 2.3 & -0.205 \\
\hline Phipps Well & 12/01/09 & 0.050 & 0.099 & 0.105 & 4.4 & -0.173 \\
\hline Wekiwa Spring & 12/01/09 & 0.072 & 0.124 & 0.142 & 2.4 & -0.269 \\
\hline Rock Spring & 12/01/09 & 0.071 & 0.095 & 0.226 & 3.4 & -0.218 \\
\hline
\end{tabular}




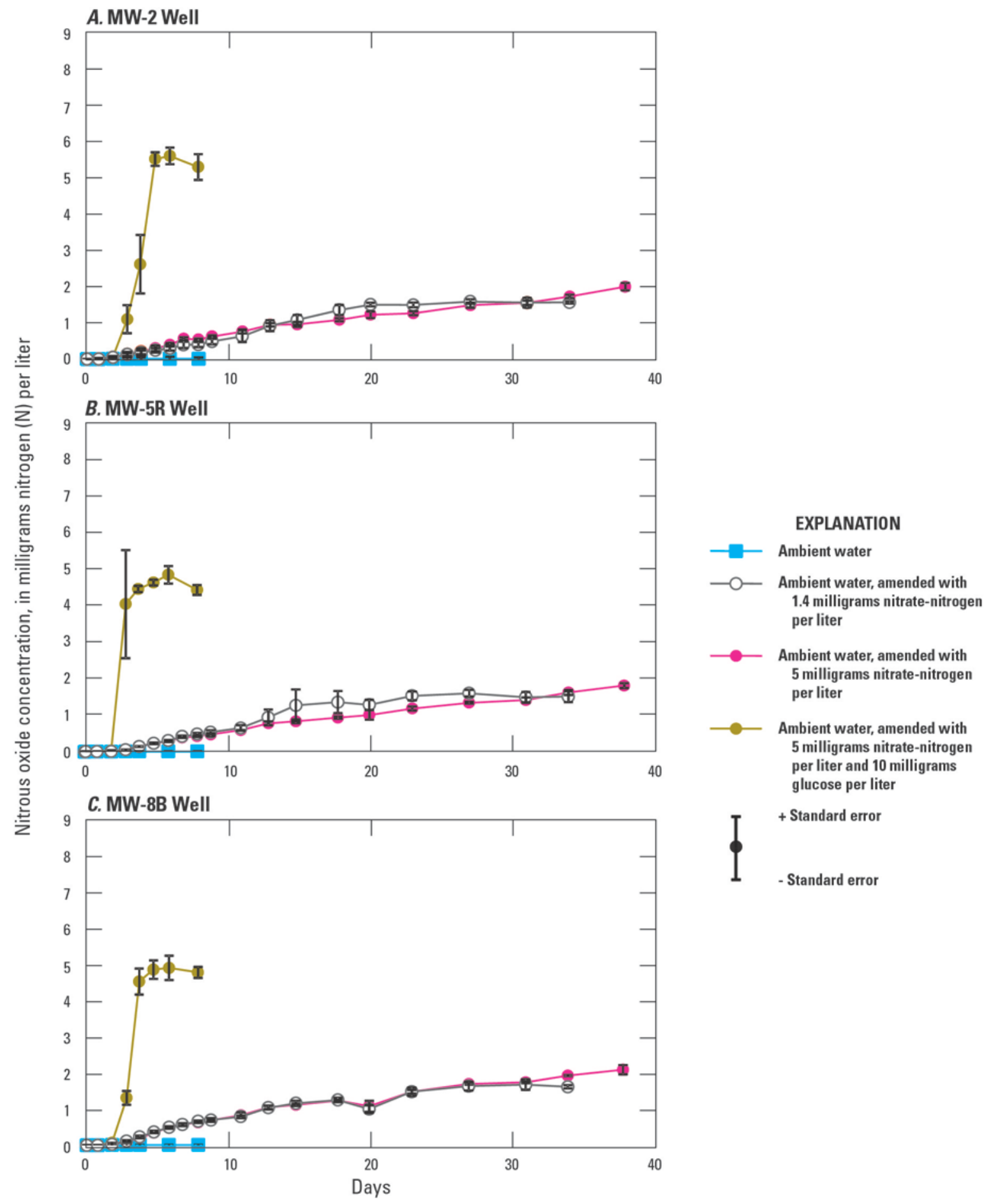

Figure 2. Graphs showing time course of nitrous oxide production by well water and spring-water samples during laboratory incubations to measure denitrification potential. 

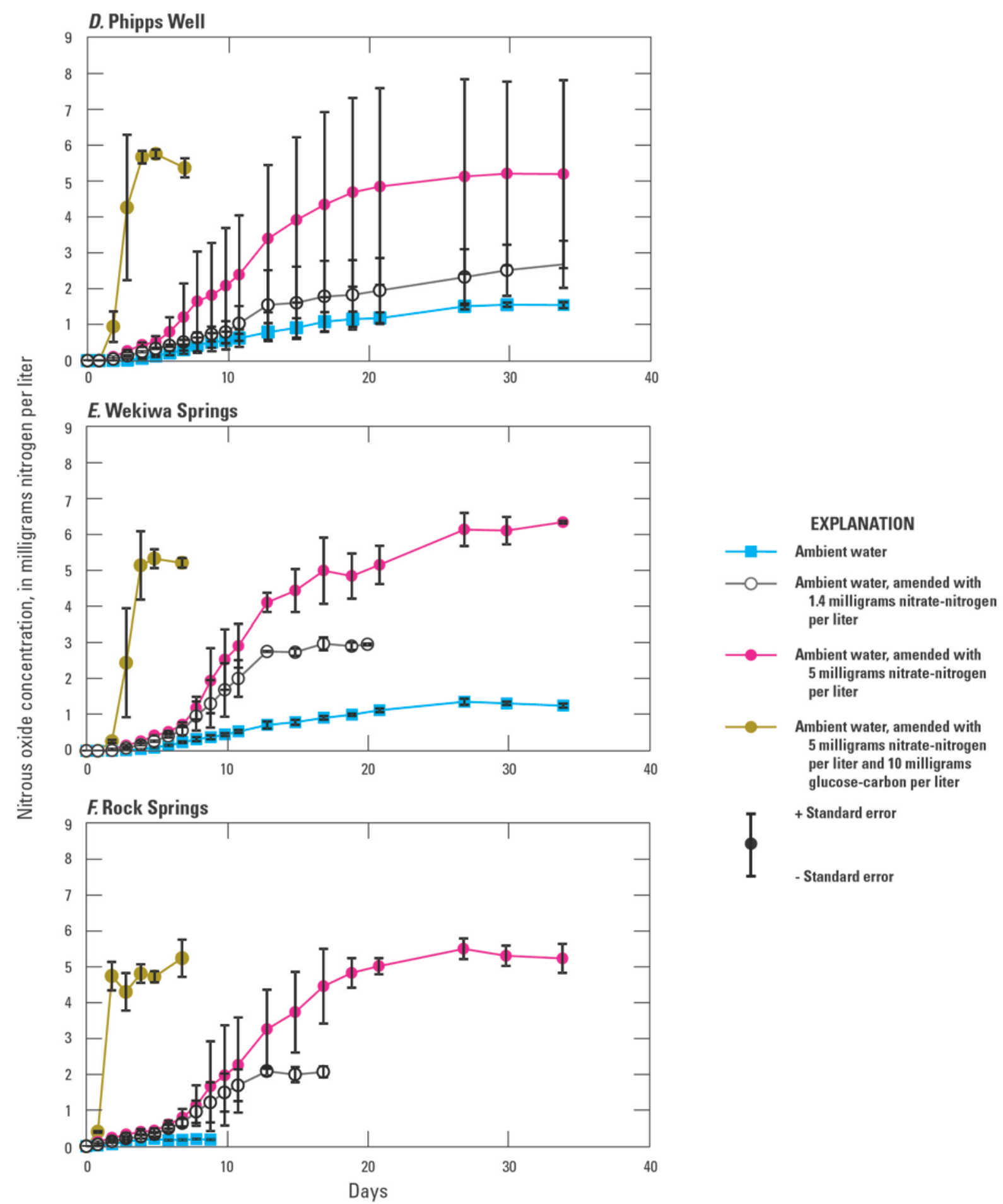

Figure 2. Graphs showing time course of nitrous oxide production by well water and spring-water samples during laboratory incubations to measure denitrification potential.-Continued 


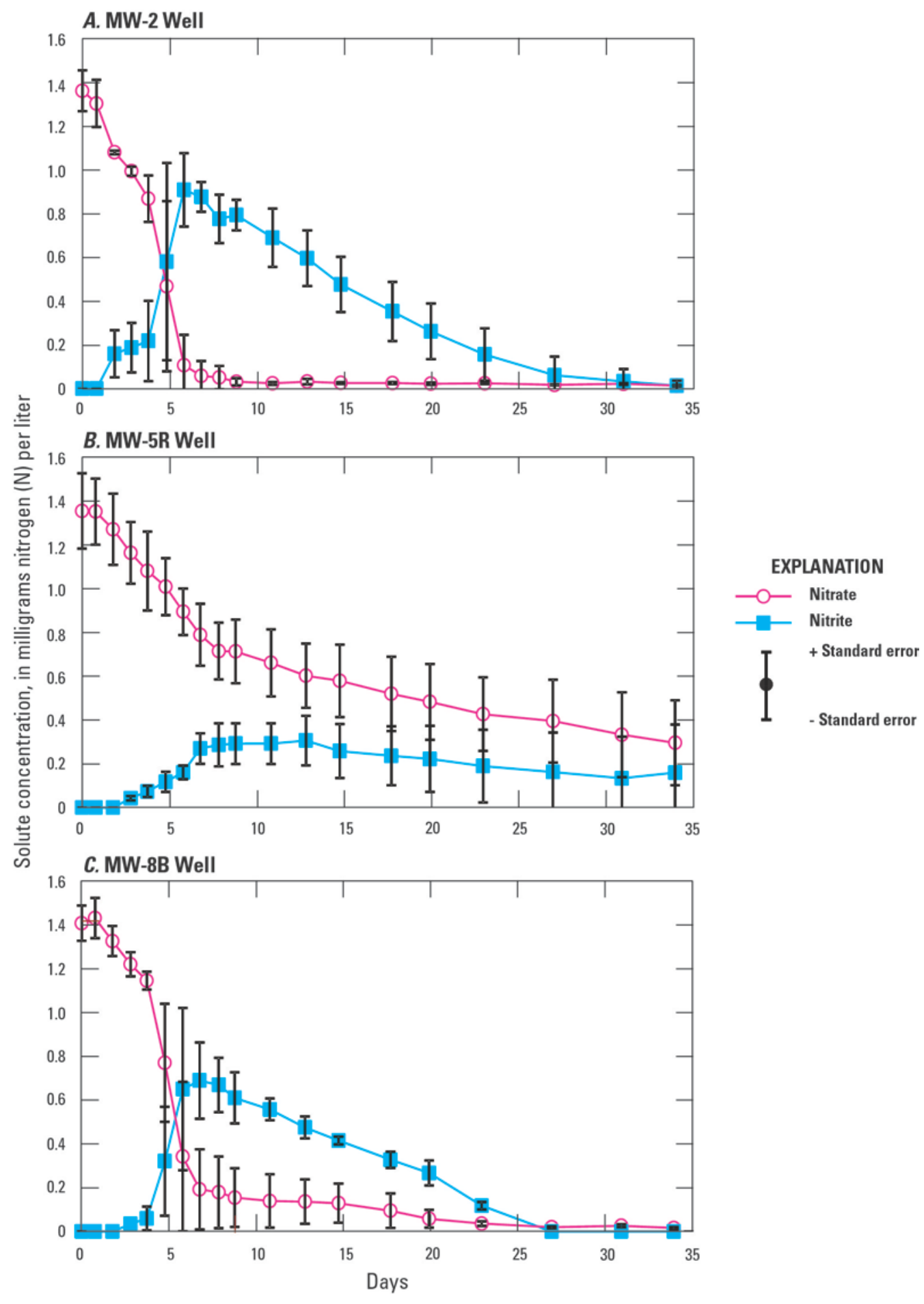

Figure 3. Graphs showing time course of nitrate and nitrite concentration change in well water and spring-water samples during laboratory incubations. 


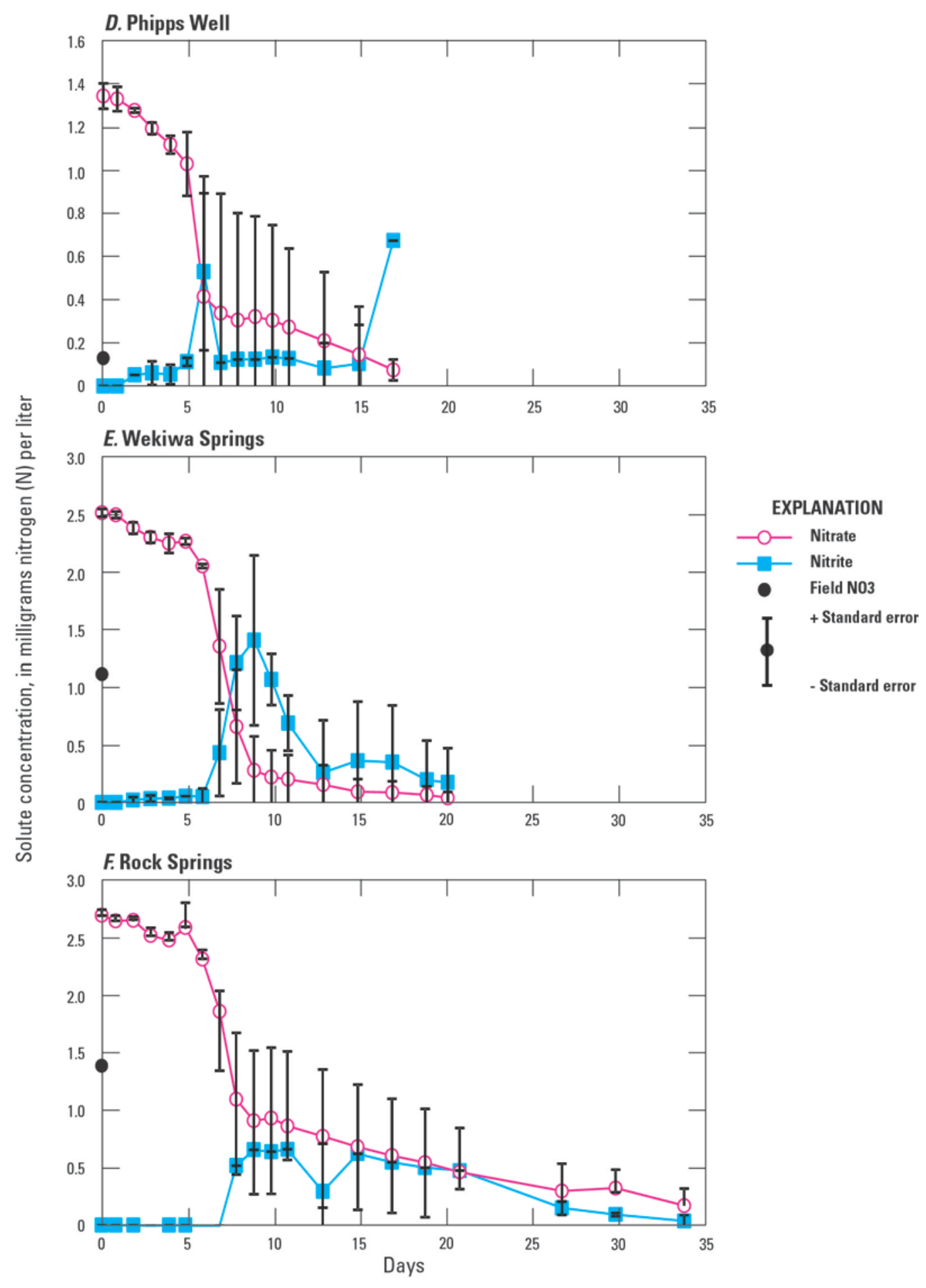

Figure 3. Graphs showing time course of nitrate and nitrite concentration change in well water and spring-water samples during laboratory incubations.-Continued 


\section{Limitations}

Smith and others (1996) in a prior study of a surficial aquifer, suggest that potential rates of denitrification determined with the anoxic laboratory samples are likely greater than rates that occur in the aquifer due to elevated dissolved oxygen concentration in the shallow aquifer of that study. However, because the Upper Floridan aquifer has low dissolved oxygen concentrations, it is doubtful that a disparity in laboratory and aquifer dissolved oxygen would bias applicability of the laboratoryderived denitrification rates to the Upper Floridan aquifer. The addition of nitrate and glucose would tend to stimulate denitrification during laboratory incubations since the relevant bacteria require nitrate and glucose to colonize and, therefore, would bias laboratory-derived denitrification rates higher than in situ aquifer rates. The laboratory results also are only relevant to denitrifying bacteria and carbon suspended in the groundwater; the experiments did not measure rates of denitrification for bacteria attached to possible carbon-rich biofilms on aquifer solids. If attached bacteria actively consume nitrate by denitrification in in situ aquifer conditions, neglect of biofilm denitrification would bias laboratoryderived denitrification rates lower than in situ aquifer rates. The data presented in this study suggest that carbon is the limiting nutrient for this reaction in the Upper Floridan aquifer.

Low nitrate concentrations in the Upper Floridan aquifer in this area make tracer studies impractical under ambient aquifer conditions and retrieval of injected enhanced-nitrate tracers is challenging in the fast-moving, conduit flow within this aquifer.

\section{Summary}

Water samples from four Upper Floridan aquifer wells and two springs were tested to determine the potential for denitrification near reclaimed water application sites in west Orange County, Florida. Tests were conducted to quantify the potential rates of denitrification using the acetylene block technique; the potential rate of denitrification was calculated as the rate of nitrate reduction to nitrous oxide within water samples, quantified by nitrous oxide production. The experiment consisted of four different treatments: (1) ambient water (no added nitrate or glucose); (2) ambient water amended with $1.4 \mathrm{mg} / \mathrm{L}$ nitrate as $\mathrm{N}$, (3) ambient water amended with $5.0 \mathrm{mg} / \mathrm{L}$ nitrate as $\mathrm{N}$, and (4) ambient water amended with $5.0 \mathrm{mg} / \mathrm{L}$ nitrate as $\mathrm{N}$ and $10 \mathrm{mg} / \mathrm{L}$ glucose as $\mathrm{C}_{6} \mathrm{H}_{12} \mathrm{O}_{6}$. Nitrate/nitrite concentrations also were monitored over time in a separate, companion set of incubation bottles subjected to treatment 2 but without addition of an acetylene block (laboratory control). These control samples were denitrified in 4-6 days with an initial lag and final concentrations of $0.04 \mathrm{mg} / \mathrm{L}$ nitrate as $\mathrm{N}$.

Results of the study indicate that denitrifying bacteria were present in the groundwater and spring water samples, and these bacteria readily facilitated denitrification when placed in suitable conditions. In three of the four well sites, the ambient nitrate concentrations were too low (less than $0.04 \mathrm{mg} / \mathrm{L}$ as $\mathrm{N}$ ) to establish a denitrification rate using treatment 1 . But in the fourth well, where the ambient nitrate concentration was $0.13 \mathrm{mg} / \mathrm{L}$ as $\mathrm{N}$, the nitrous oxide production rate for treatment 1 was 0.050 milligram per liter per day $[(\mathrm{mg} / \mathrm{L}) / \mathrm{d}] \mathrm{N}$. When nitrate was added for treatments 2 and 3 , the denitrification rate increased. In four of the six sites, the denitrification rate was similar in treatments 2 and 3. This finding may indicate that when nitrate exceeds about $1.4 \mathrm{mg} / \mathrm{L}$ as $\mathrm{N}$, the denitrification rate is not limited by available nitrate. The denitrification rate, in all the samples ranged from 0.059 to 0.124 (mg/L)/d N (treatment 2) and 0.071 to 0.226 (mg/L)/d N (treatment 3). Treatment 4 yielded nitrous oxide production rates at least an order of magnitude greater than those measured for the other treatments, at all of the sampling sites; rates ranged from 2.3 to $4.4(\mathrm{mg} / \mathrm{L}) / \mathrm{d}$ N. The electron donor supply, dissolved organic carbon, in the groundwater and springwater is sufficient to remove at least 1.1-1.4 mg/L nitrate as $\mathrm{N}$ in 20 to 30 days, as indicated by nitrous oxide production rates under ambient 
conditions (treatment 1). The even higher nitrate removal observed with addition of supplemental carbon in treatment 4 suggests that carbon is a limiting nutrient in this reaction. Denitrifying activity might explain the low ambient nitrate concentrations in the Upper Floridan aquifer. The in situ rates of denitrification were calculated as $5 \times 10^{-4} \mathrm{mg} / \mathrm{L}$ as $\mathrm{N}$ per day based on groundwater age and excess nitrogen gas concentrations data collected by Kroening(2007). The potential rates of denitrification determined in the low dissolved oxygen laboratory incubations during this study may represent in situ rates of denitrification because, in contrast to previous studies of shallow aquifers with oxygenated conditions that retard denitrification, low dissolved oxygen concentrations prevail in the Upper Floridan aquifer.

The potential for denitrification exists in the Upper Floridan aquifer near a reclaimed water application site in west Orange County, Florida. The necessary conditions for denitrification, including the presence of denitrifying bacteria, relatively low dissolved oxygen concentrations, and ample dissolved organic carbon are met. The laboratory-derived rates of denitrification in this study represent a reasonable approximation for actual rates in the Upper Floridan aquifer in the study area. Fertilizer appears to be the primary source of nitrate in the Upper Floridan aquifer beneath the rapid infiltration basin sites.

\section{References Cited}

Adamski, J.C., and German, E.R., 2003, Hydrogeology and quality of ground water in Orange County, Florida: U.S. Geological Survey Water-Resources Investigations Report 03-4257, 113 p.

Balderston, W.L., Sherr, B., and Payne, W.J., 1976, Blockage by acetylene of nitrous oxide reduction in Pseudomonas perfectomarinus: Applied and Environmental Microbiology v. 31, p. 504-508.

Katz, B.G., and Böhlke, J.K., 2000, Monthly variability and possible sources of nitrate in groundwater beneath mixed agricultural land use, Suwannee and Lafayette Counties, Florida: U.S. Geological Survey Water-Resources Investigations Report 00-4219, 28 p.

Katz, B.G., Hornsby, H.D., Böhlke, J.F., and Mokray, M.F., 1999, Sources and chronology of nitrate contamination in spring waters, Suwannee River Basin, Florida: U.S. Geological Survey WaterResources Investigations Report 99-4252, 54 p.

Kroening, S.E., 2007, Sources of nitrate and evaluating the potential for denitrification in the surficial and Upper Floridan aquifers, central Florida, in Proceedings of the Fourth National Outdoor Action Conference on Aquifer Restoration, Ground Water Monitoring and Geophysical Methods, Safety Harbor, FL, February 27-28, 2007: National Ground Water Association.

Marella, R.L., 2009, Water withdrawals, use, and trends in Florida, 2005: U.S. Geological Survey Scientific Investigations Report 2009-5125, 49 p.

Morrell, R.A., MacIntyre, D., Teegarden, R., and Delneky, G., 2002, Effluent disposal and water supply coming together at Orange County northwest water reclamation facility: Florida Water Resources Journal, p. 41-44. 
Murray, L.C., and Halford, K.J., 1996, Hydrogeologic conditions and simulation of ground-water flow in the greater Orlando metropolitan area, east-central Florida: U.S. Geological Survey WaterResources Investigations Report 96-4, 100 p.

O’Reilly, A.M., 1998, Hydrogeology and simulation of the effects of reclaimed-water application in west Orange and southeast Lake Counties, Florida: U.S. Geological Survey Water-Resources Investigations Report 97-4199, 91 p.

Savoie, J., and LeBlanc, D.R., 1998, Water-quality data and methods of analysis for samples collected near a plume of sewage-contaminated ground water, Ashumet Valley, Cape Cod, Massachusetts, 1993-1994: U.S. Geological Survey-Water Resources Investigations Report 97-4269, 208 p.

Schlosser, P., [n.d.], ${ }^{3} \mathrm{H} /{ }^{3} \mathrm{He}$ sampling: Accessed on December 29, 2011, at http://water.usgs.gov/lab/3h3he/sampling.

Schlosser P., Stute, M., Dorr, H., Sonntag, C., and Munnich, K.O., 1988, Tritium/ ${ }^{3}$ He dating of shallow groundwater: Earth and Planetary Science Letters, v. 89, p. 353-362.

Schlosser, P., Turrin, B.D., and Klas, M., 2008, Tritium/He measurements for the USGS: LamontDoherty Earth Observatory Noble Gas Laboratory, Palisades, N.Y. : Data Release no. 08-1.15.0.

Sepulveda, Nicasio, 2002, Simulation of ground-water flow in the intermediate and Floridan aquifer systems in peninsular Florida: U.S. Geological Survey Water-Resources Investigations Report 02-4009, 130 p.

Smith, R.L., Böhlke, J.K., Garabedian, S.P., Revesz, K.M., and Yoshinari, T., 2004, Assessing denitrification in groundwater using natural gradient tracer tests with $15 \mathrm{~N}$ : In situ measurements of a sequential reaction: Water Resources Research, v. 40, W07101, doi: 10.1029/2003WR002919.

Smith, R.L., and Duff, J.H., 1988, Denitrification in a sand and gravel aquifer: Applied and Environmental Microbiology v. 54, p. 1071-1078.

Smith, R.L., Garabedian, S.P., and Brooks, M.H., 1996, Comparison of denitrifying activity measurements in groundwater using cores and natural-gradient tracer tests: Environmental Science and Technology v. 30, p. 3448-3456.

Sumner, D.M., and Bradner, L.A., 1996, Hydraulic characteristics and nutrient transport and transformation beneath a rapid infiltration basin, Reedy Creek Improvement District, Orange County, Florida: U.S. Geological Survey Water-Resources Investigations Report 95-4281, 51 p.

Toth, D.J., and Fortich, C., 2002, Nitrate concentrations in the Wekiva groundwater basin with emphasis on Wekiwa Springs: Palatka, Fla., St. Johns River Water Management District Technical Publication SJ2002-2. 
Turrin, B., [n.d.], Introduction to $\mathrm{T} /{ }^{3} \mathrm{He}$ dating of ground water sampling and measurement methods (no rates no dates): Accessed on December 29, 2011, at http://rockbox.rutgers.edu/nbhydro/abs/BrentTurin-II.pdf.

Unterweger, M.P., Coursey, B.M., Schima, F.J., and Mann, W.B., 1980, Preparation and calibration of the 1978 National Bureau of Standards tritiated-water standards: International Journal of Applied Radiation and Isotopes, v. 31, p. 611- 614.

U.S. Geological Survey, The Reston Chlorofluorocarbon Laboratory, Undated, ${ }^{3} \mathrm{H} /{ }^{3} \mathrm{He}$ dating background: Accessed on December 29, 2011, at http://water.usgs.gov/lab/3h3he/background/.

Walsh, S.J., Knowles, L., Jr., Katz, B.G., and Strom, D.G., 2009, Hydrology, water quality, and aquatic communities of selected springs in the St. Johns River Water Management District, Florida: U.S. Geological Survey Scientific Investigations Report 2009-5046, 115 p.

Walsh, V. and Price, R. 2010, ${ }^{3} \mathrm{H}$ and ${ }^{3}$ HeTritium and Helium Apparent Age dating of Groundwaters: Accessed on December 29, 2011, at http://www2.fiu.edu/ pricer/Radioisotopes.pdf.

Yoshinari, T., Hynes, R., and Knowles, R., 1977, Acetylene inhibition of nitrous oxide reduction and measurement of denitrification and nitrogen fixation in soil: Soil Biology and Biochemistry, v. 9, p. 177-183. 


\section{Appendix 1. Sources of Nitrate and Evaluating the Potential for Denitrification in the Surficial and Upper Floridan Aquifers, Central Florida}

The following article by Sharon E. Kroening is reprinted from Proceedings of the Fourth National Outdoor Action Conference on Aquifer Restoration, Ground Water Monitoring and Geophysical Methods with permission of the National Ground Water Association. Copyright 1990. Refer to Kroening (2007) in the references cited section for the complete report citation. 


\title{
Sources of Nitrate and Evaluating the Potential for Denitrification in the Surficial and Upper Floridan Aquifers, Central Florida
}

\author{
Sharon E. Kroening \\ U.S. Geological Survey \\ Orlando, Florida
}

\begin{abstract}
The sources of nitrate and potential for denitrification were evaluated in the karstic Upper Floridan aquifer (UFA) and overlying surficial aquifer beneath and upgradient from a reclaimed water facility in Central Florida. Nitrate-N concentration $(<0.02$ to $6.3 \mathrm{mg} / \mathrm{L})$ in ground water in this area likely originated from past fertilizer use in citrus agriculture or treated wastewater applied to rapid-sand infiltration beds. Chemical, isotopic, and dissolved gas data were evaluated from water samples collected from nine wells to determine nitrate sources and if conditions were conducive for denitrification. Surficial aquifer wells ranged from 3.7 to $23.8 \mathrm{~m}$ deep, and UFA wells ranged from 46 to $102 \mathrm{~m}$ deep. $\delta^{15} \mathrm{~N}$ and $\delta^{18} \mathrm{O}$ values of nitrate in well water samples indicated that treated wastewater likely is the source of nitrate in the surficial aquifer wells, whereas the sources of nitrate in the UFA were likely treated wastewater and fertilizer. Denitrification likely occurs in the UFA, but may only occur to a limited extent in the surficial aquifer. Dissolved oxygen concentrations generally were less than $1 \mathrm{mg} / \mathrm{L}$ in the UFA and greater than $2 \mathrm{mg} / \mathrm{L}$ in the surficial aquifer. Dissolved gas and isotopic data indicated that denitrification had occurred in water from 4 of 5 UFA wells. Excess nitrogen gas $\left(\mathrm{N}_{2}\right)$, the end product of denitrification, was estimated for four UFA wells based on the concentrations of dissolved $\mathrm{N}_{2}$ and argon in ground water. Excess $\mathrm{N}_{2}$ concentrations ranged from 1 to $5 \mathrm{mg} / \mathrm{L}$. $\delta^{15} \mathrm{~N}$ values associated with $\mathrm{N}_{2}$ in these same wells also were substantially greater $\left(+0.97\right.$ to $+2.14 \%$ ) than for $\mathrm{N}_{2}$ in equilibrium with airsaturated water. Denitrification may naturally attenuate some nitrate in the UFA before it is transported to natural springs in the area.
\end{abstract}

\section{Introduction}

Karstic aquifer systems supply water to approximately 25 percent of the world's population (Williams, 1993) and are extremely susceptible to nitrate contamination due to the rapid recharge of these systems through sinkholes and other subsidence features, sinking streams, and preferential flow paths created by conduits. High nitrate concentrations in these systems pose a threat to the quality of potable water supplies and may affect the ecosystems surrounding karstic springs, which evolved under nutrient-limited conditions in parts of the U.S. (Stevenson et. al., 2004). Specifically, the nuisance growth of filamentous algae may be associated with increased nitrate concentrations and were identified as a problem for recreational use and aquatic life support in springs (Stevenson et. al., 2004).

The karstic Upper Floridan aquifer (UFA) is the primary source of water in Central Florida (St. Johns River Water Management District, 2006a) and discharges to numerous 
natural springs. Approximately $3.3 \times 10^{6} \mathrm{~m}^{3} /$ day were withdrawn from the UFA in Central Florida in 2000 (Marella, 2004). Ground water use is projected to increase about 60 percent by the year 2025 due to projected population increases for the area (St. Johns River Water Management District, 2006b). Ground water from the UFA is being withdrawn near the maximum sustainable rate (St. Johns River Water Management District, 2006a), and measures are being implemented to replenish this aquifer system to help ensure that adequate water supplies are available to meet projected water-supply demands and sustain the ground water inflow to the many natural springs. Artificial recharge with treated wastewater, or reclaimed water, is one management technique which is becoming widely utilized to recharge the UFA in Florida and aquifer systems in other parts of the U.S. (York et. al. 2002; U.S. Environmental Protection Agency 2004; St. Johns River Water Management District 2006a). In many of these applications, reclaimed water is discharged to rapid-sand infiltration basins (RIBs) and allowed to percolate into the ground (Brooke and Godlewski 1995; O’Reilly 1998; U.S. Environmental Protection Agency 2004).

Artifically-recharged water from RIBS, while providing beneficial recharge to the ground water system, may potentially contaminate the UFA with nitrate. Wastewater disposal to RIBS in other parts of the U.S. resulted in nitrate contamination of the ground water (Aulenbach and Tofflemire, 1975; LeBlanc, 1984). Disposal of treated wastewater for over 60 years in the Cape Cod, Massachusetts resulted in a $3.5 \mathrm{~km}$-long plume containing nitrate concentrations greater than $3 \mathrm{mg} / \mathrm{L}$ (LeBlanc, 1984). Knowledge of the source and fate of nitrate in the ground water system is necessary in order to develop effective management strategies to prevent or remediate nitrate contamination. Denitrification, nitrate reduction to $\mathrm{N}_{2}$ gas, generally is considered the primary nitrate attenuation mechanism in contaminated aquifers (Korom 1992). Numerous studies have documented the potential for denitrification in surficial sand and gravel aquifers (Wassenaar 1995; Starr and Gillham 1993; Smith and Duff 1988). Denitrification in karstic aquifers, such as the UFA, often is believed to be insignificant due to the rapid transport velocities of oxygenated water through these systems (Coxon 1999), however, the potential for denitrification has been reported in several karstic aquifers based on dissolved gas or stable isotope data (Panno et. al. 2001; Wilson et. al. 1990; Mariotti et. al. 1988).

This paper presents the results of a study conducted from 2004-2006 by the U.S. Geological Survey in cooperation with Orange County, Florida to determine the nitrate sources in the karstic UFA and surficial aquifer system (SAS) beneath and upgradient from a wastewater treatment and reuse facility (WWTRF). Chemical data were used to determine whether conditions in these aquifers were conducive for denitrification to occur. Nitrogen and oxygen isotope ratios on the nitrate in water samples and $\mathrm{N}$ isotope ratios on the $\mathrm{N}_{2}$ gas dissolved in the water samples were examined for evidence of denitrification and were used to determine nitrate sources. Dissolved gas $\left(\mathrm{N}_{2}\right.$ and $\mathrm{Ar}$ ) concentrations were used to estimate recharge temperatures and the amount of $\mathrm{NO}_{3}{ }^{-}$consumed by denitrification. $\mathrm{N}_{2} \mathrm{O}$ concentration data were used to identify whether active areas of denitrification were present. 
The study was conducted in the SAS and UFA in a nine $\mathrm{km}^{2}$ area in Central Florida (Fig. 1). The mean annual air temperature in this area is approximately $22.0^{\circ} \mathrm{C}$ (Adamski and German, 2005). Regional ground-water flow in the UFA generally is from the southwest to the northeast (Kinnaman, 2006), and ground water discharge occurs through several springs to the north and northeast of the study area, most notably Wekiwa and Rock Springs. The UFA is characterized by primary and secondary porosity (Spechler and Halford 2001), and generally is separated from the SAS by a confining unit consisting of low permeability Miocene or early Pliocene-age carbonate and siliceous deposits, except where the confining unit is breached by sinkholes. Within the study area, the UFA is mantled by about 140 to 150 feet of post-Miocene and Miocene-age deposits, and the uppermost deposits generally are described as consisting of fine-grained sand which grades into silty and clayey fine sands (Morrell et. al. 2002).

A WWTRF occupies approximately one-third of the study area and has been operated since 1987 to treat domestic waste. Other land uses in the study area include agriculture and low- and medium-density residential developments, which are primarily located to the north and east of the WWTRF. Current agricultural land use consists of ornamental nurseries, abandoned tree crops, and pasture. Prior to the construction of this facility, citrus agriculture likely was the predominant land use (Florida Department of Environmental Protection, 2004).

Rainfall and treated wastewater effluent are the predominant sources of recharge water to SAS and UFA in the study area. Central Florida typically receives about $130 \mathrm{~cm}$ of rainfall per year, with the majority occurring from June through September (Adamski and German 2004). The WWTRF discharged approximately $61.8 \times 10^{6} \mathrm{~m}^{3}$ of treated wastewater to 13 RIBs from 1990-2003. Most of the wastewater was discharged to RIB 1 (34 percent), 5 (16 percent), and 12 (12 percent), which have the greatest infiltration rates (1.6-1.9 m/day) (Post Buckley Schuh \& Jernigan, Inc., 1993). The other RIBs each received less than 6 percent of the treated wastewater.

\section{Methods}

\section{Site Selection}

Nine SAS and UFA wells were sampled for this study at five sampling sites (Fig. 1). Eight of these wells were located in the vicinity of the WWTRF and one UFA well was located upgradient of the facility. Existing UFA wells, ranging from about 46 to $102 \mathrm{~m}$ deep were sampled at sites 2 (45.7 $\mathrm{m}$ deep), 4 (51.8 $\mathrm{m}$ deep), and 5 (102 $\mathrm{m}$ deep). A 64.0-m deep UFA well was installed at site 3 in December 2004 to replace an existing monitoring well. At site 1, a vertical sequence of SAS wells (wells 1-A, 1-B, 1-C, and 1-D), ranging from 3.7 to $23.8 \mathrm{~m}$ deep, and one UFA well (well 1-E, $62.5 \mathrm{~m}$ deep) were installed in December 2004 (Fig. 2) to replace an existing UFA monitoring well and characterize any vertical gradient in 


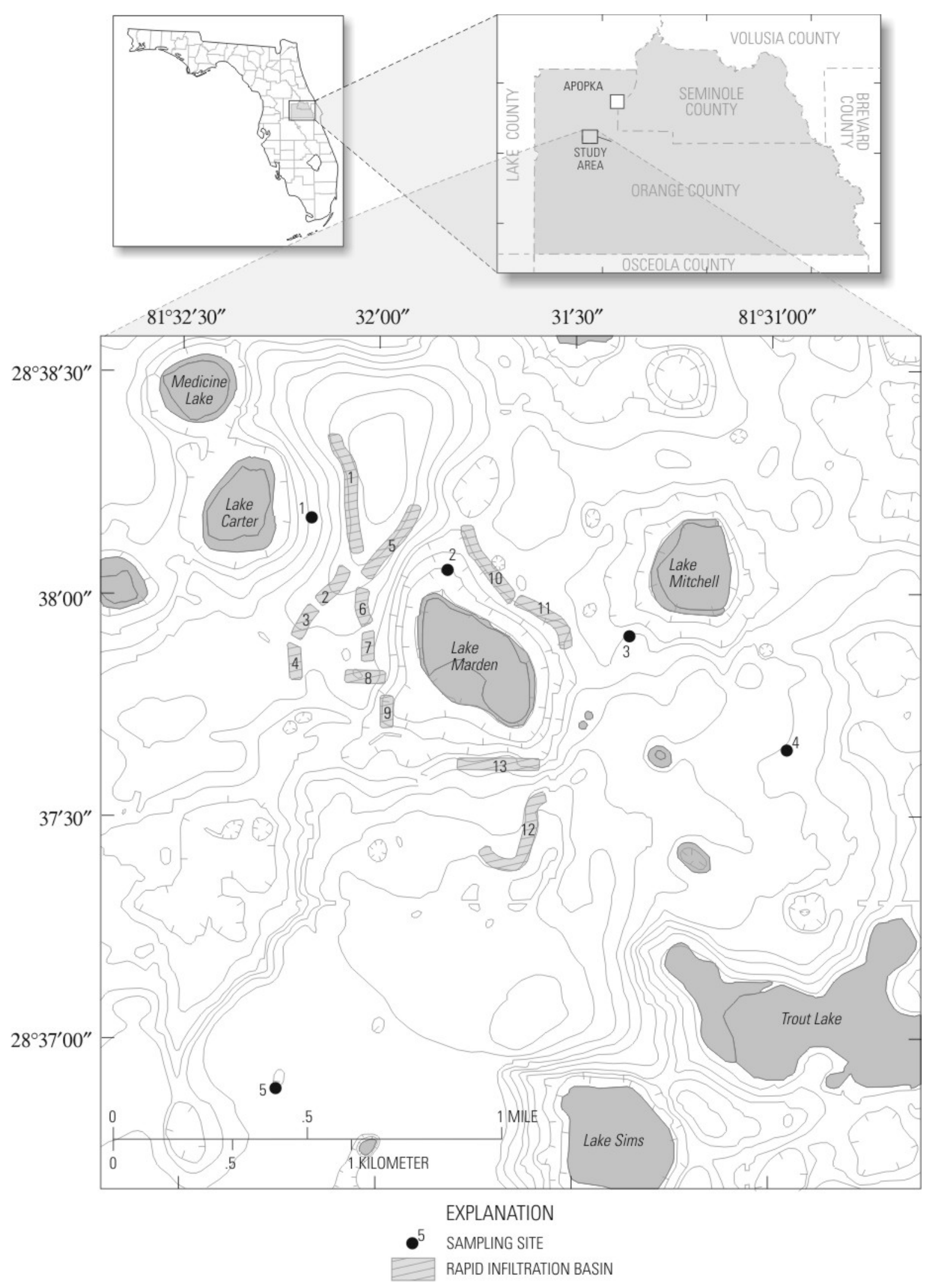

Figure 1. Location of the study area, rapid-infiltration basins, and sampling sites. 
the denitrification potential. SAS wells were screened to 1.5-3.0 m intervals. The UFA wells were not screened and the open-hole interval for these wells ranged from 3.0-31.7 m. UFA Well 5 had the longest open-hole interval. The open-hole intervals for the other UFA wells were $15.2 \mathrm{~m}$ or less.

Lithologic and ground-water level data collected at site 1 in 2004 showed the direction of the vertical head gradient was downward and there was substantial confinement between most of the SAS wells. Ground-water level measurements showed there was a downward vertical head gradient among the SAS and UFA wells at site 1 during all sampling events. Lithologic data collected prior to drilling at this site showed clay layers were interbedded among the sands comprising the SAS, which resulted in substantial water confinement between most of the SAS layers. The most substantial confinement occurred between wells 1-B through 1-D. The median difference in ground water levels between wells $1-\mathrm{B}$ and 1-C was $9.4 \mathrm{~m}$, and the median difference in ground water levels between wells 1-C and 1-D was $3.4 \mathrm{~m}$. Of all the SAS wells, ground water levels in wells 1-A and 1-B were the most similar, with a median difference in ground water levels of $0.2 \mathrm{~m}$.

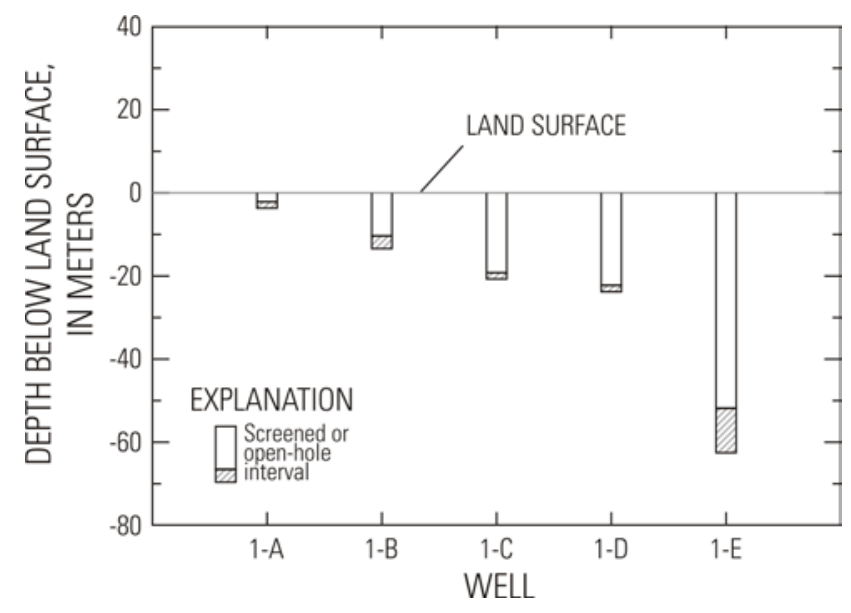

Figure 2. Placement of well cluster at site 1.

\section{Water-quality sampling}

Water samples were collected from October 2004 to April 2006. All wells except number 5 were sampled using a stainless steel submersible pump with PVC tubing. Well 5 supplied potable water to a toll plaza. Water samples were withdrawn from this well at a point upgradient of the pressure tank using the dedicated submersible pump. Samples collected for analysis of $\mathrm{N}_{2} \mathrm{O}$ dissolved in the ground water were collected only in 2006, and samples were not collected from well 1-A because the well was dry. Most samples were collected using standard techniques (Wilde et. al., 1999) after a minimum of three well-bore volumes of water were purged and field readings of specific conductance, $\mathrm{pH}$, dissolved oxygen, and temperature stabilized. A closed flow-through chamber was used to measure water temperature, specific conductance, and $\mathrm{pH}$. Dissolved oxygen concentrations were measured using a polargraphic probe during October 2004-2005 and using a colorimetric reagent in ampoules and a battery-operated spectrophotometer (Chemetrics Inc. Calverton 
VA, USA) (use of trade names is for identification purposes only and does not imply endorsement by the U.S. Government) in 2006. Water samples for $\mathrm{N}$ and $\mathrm{O}$ isotope analysis were filtered using an encapsulated $0.45 \mu \mathrm{m}$ filter into 125 -mL plastic bottles and kept frozen until analysis. Water samples for $\mathrm{N}_{2}, \mathrm{Ar}, \mathrm{CO}_{2}$, and $\mathrm{CH}_{4}$ determinations were collected in 150$\mathrm{mL}$ serum bottles without headspace. For $\mathrm{N}_{2} \mathrm{O}$ determinations, 20-mL water samples were collected in a syringe and injected into stoppered $30-\mathrm{mL}$ serum vials containing $0.2 \mathrm{~mL}$ of $12.5 \mathrm{~N} \mathrm{KOH}$ in a He headspace.

\section{Analytical procedures}

$\mathrm{NO}_{3}^{-}, \mathrm{NO}_{2}^{-}$, and $\mathrm{NH}_{4}{ }^{+}$were analyzed in water samples using established methods (EPA 300.0; Fishman, 1993) at the USGS laboratory in Denver, Colorado or the Orange County laboratory in Orlando, Florida. Organic carbon and boron were analyzed using established methods (EPA 200.7, SM5310C) at the Orange County laboratory in Orlando, Florida. Dissolved $\mathrm{N}_{2}, \mathrm{Ar}, \mathrm{CO}_{2}$, and $\mathrm{CH}_{4}$ gases in the samples were analyzed by gas chromatography after extraction in headspaces of glass samplers (Busenberg et. al. 1998). The isotopic composition of $\mathrm{N}_{2}$ in the water samples, $\delta^{15} \mathrm{~N}$ of $\mathrm{N}_{2}$, was measured in the leftover headspace after the $\mathrm{N}_{2}, \mathrm{Ar}, \mathrm{CO}_{2}$, and $\mathrm{CH}_{4}$ analysis. The headspace was pressurized with $\mathrm{He}$, expanded into a $0.1 \mathrm{~mL}$ loop, then flushed with He through a $5 \mathrm{~A}$ mole sieve gas chromatograph to separate $\mathrm{O}_{2}+\mathrm{Ar}$ from $\mathrm{N}_{2}$ (modified from Revesz et al., 1999; Smith et al., 2006). These peaks were passed through an open split to the ion source of a Finnigan Delta Plus XL mass spectrometer (use of trade names is for identification purposes only and does not imply endorsement by the U.S. Government) and monitored in continuous-flow mode at $\mathrm{m} / \mathrm{z}$ 28, 29, 32, 34, 36, and 40. Relative peak areas at $\mathrm{m} / \mathrm{z} 28$ and 40 (from $\mathrm{N}_{2}$ and Ar) were used to confirm sample integrity between the concentration measurements and the isotopic analyses. Values of $\delta^{15} \mathrm{~N}$ are reported with respect to atmospheric $\mathrm{N}_{2}(0 \%)$ and were calibrated by analyses of air-saturated water samples ( $+0.65 \%$ ) that were collected in serum bottles and treated the same way as the samples, with estimated uncertainties of approximately $\pm 0.1 \%$ (1-sigma). $\mathrm{N}$ and $\mathrm{O}$ isotopes in aqueous $\mathrm{NO}_{3}{ }^{-}, \delta^{15} \mathrm{~N}$ of $\mathrm{NO}_{3}{ }^{-}$and $\delta^{18} \mathrm{O}$ of $\mathrm{NO}_{3}{ }^{-}$, were analyzed by bacterial conversion of nitrate to nitrous oxide and subsequent measurement on a continuous flow isotope ratio mass spectrometer as described by Sigman et. al. (2001), Casciotti et. al. (2002), Coplen et. al. (2004), and Revesz and Casciotti (2005). Nitrogen isotope ratios are reported relative to $\mathrm{N}_{2}$ in air (Mariotti, 1983). $\delta^{15} \mathrm{~N}$ of $\mathrm{NO}_{3}{ }^{-}$values were normalized to values of $+4.72 \%$ for International Atomic Energy isotopic standard NO-3 and $+180.0 \%$ for USGS-32. $\delta^{18} \mathrm{O}$ of $\mathrm{NO}_{3}{ }^{-}$values were reported on a scale such that the Vienna Standard Mean Ocean Water (VSMOW) was $0 \%$ and the Standard Light Antarctic Precipitation was -55.5 \%o relative to the VSMOW (Coplen, 1988, 1994). The reported $\delta^{18} \mathrm{O}$ data were calibrated by assuming the following values for internationally distributed nitrate isotopic reference materials (Böhlke and others, 2003): IAEA-NO-3 (+25.6\%), USGS32 (+25.7 \%), USGS34 (-27.9\%), and USGS35 (+57.5\%). The analytical uncertainties for $\delta^{15} \mathrm{~N}$ of $\mathrm{NO}_{3}{ }^{-}$and $\delta^{18} \mathrm{O}$ of $\mathrm{NO}_{3}{ }^{-}$results were \pm 0.5 and $\pm 1.0 \%$, respectively (2-sigma). $\mathrm{N}_{2} \mathrm{O}$ concentrations were determined by gas chromatography with an electron capture detector as described by Smith and Duff (1988) at the USGS laboratory in Boulder, Colorado. 


\section{Reconstruction of Initial Nitrate Concentration and Isotopic Composition}

The initial concentration and isotopic composition of $\mathrm{NO}_{3}{ }^{-}$was estimated for wells where excess $\mathrm{N}_{2}$ gas resulting from denitrification was estimated to be present. The initial $\mathrm{NO}_{3}{ }^{-}$concentration present in the ground water prior to the onset of denitification was estimated as the sum of the measured $\mathrm{NO}_{3}{ }^{-}$and excess $\mathrm{N}_{2}$. The initial isotopic composition of the $\mathrm{NO}_{3}{ }^{-}$concentration, $\delta^{15} \mathrm{~N}$ of $\mathrm{NO}_{3}{ }^{-0}$, present in the ground water prior to the onset of denitification, was estimated by an isotopic mass balance as described by Böhlke et. al. (2002).

\section{Results and Discussion}

\section{Chemical and Isotopic Composition of the Treated Effluent}

The treated effluent discharged to the RIBS contained high concentrations of $\mathrm{NO}_{3}{ }^{-} \mathrm{N}$, organic carbon, and boron. Measured $\mathrm{NO}_{3}{ }^{-}$concentrations from 2004-2006 ranged from $1.37-6.93 \mathrm{mg} / \mathrm{L}$ as $\mathrm{N}$. Organic carbon and boron concentrations measured in an effluent sample in November 2004 were $6.1 \mathrm{mg} / \mathrm{L}$ as $\mathrm{C}$ and $0.24 \mathrm{mg} / \mathrm{L}$, respectively. $\delta^{15} \mathrm{~N}$ of $\mathrm{NO}_{3}{ }^{-}$ values from effluent samples had a wide variation (+9.46 to $+29.07 \%$ ) which resulted from periodic denitrification of the effluent at the WWTRF.

\section{Evidence for Denitrification}

Chemical conditions were conducive for denitrification to occur in the UFA but generally not in the SAS. The UFA wells contained organic carbon, varying amounts of $\mathrm{NO}_{3}{ }^{-}$ , and little $\mathrm{O}_{2}$. Dissolved $\mathrm{O}_{2}$ concentrations in water from all UFA wells were less than 1 $\mathrm{mg} / \mathrm{L}$. Ground waters exhibiting evidence of denitrification typically have concentrations less than approximately $2 \mathrm{mg} / \mathrm{L}$ (Böhlke et. al., 2002). Organic carbon was present in all UFA wells at concentrations ranging from $0.4-1.7 \mathrm{mg} / \mathrm{L}$, and was highest $(0.9-1.7 \mathrm{mg} / \mathrm{L})$ in water samples from well $5 . \mathrm{NO}_{3}{ }^{-}$was present in water from UFA wells 1-E, 2, and 4, but was not detectable in samples from wells 3 and $5 . \mathrm{NO}_{3}{ }^{-}$concentrations were highest in well 1-E $(1.78-3.17 \mathrm{mg} / \mathrm{L}$ as $\mathrm{N})$ and $4(0.44-0.77 \mathrm{mg} / \mathrm{L}$ as $\mathrm{N}) . \mathrm{NO}_{3}{ }^{-}$was detected at low concentrations $(0.02-0.05 \mathrm{mg} / \mathrm{L}$ as $\mathrm{N})$ in water from well 2 from 2004-2005 but was not detected in water samples collected in 2006. Water from the SAS wells typically contained oxic water with higher concentrations of organic carbon and $\mathrm{NO}_{3}{ }^{-}$compared to the UFA. Dissolved $\mathrm{O}_{2}$ concentrations in the SAS wells ranged from 1.5-8.4 mg/L, and organic carbon concentrations ranged from $0.6-3.9 \mathrm{mg} / \mathrm{L}$. $\mathrm{NO}_{3}{ }^{-}$concentrations generally were elevated in the SAS wells compared to the UFA and ranged from $1.20-6.30 \mathrm{mg} / \mathrm{L}$ as N. Aerobic degradation of organic carbon likely was occurring in the part of the SAS represented by well 1-B, which resulted in increased $\mathrm{CO}_{2}$ concentrations and lower $\mathrm{pH}$ values in water from this well. Water from well 1-B had $\mathrm{PCO}_{2}$ values ranging from 5.1-7.3 kPa, which were approximately 150200 times higher than values in ambient air. Water $\mathrm{pH}$ values also were lower in well 1-B (5.1-6.2 units) due to the high PCO2 values and were about 1 unit lower than the $\mathrm{pH}$ of water from well 1-A which represents an overlying part of the SAS. 
Anomalously high apparent recharge temperatures calculated based on the $\mathrm{N}_{2}$ and $\mathrm{Ar}$ data in 4 of the 5 UFA wells indicated there was an additional source of $\mathrm{N}_{2}$ in the ground water, which was attributed to denitrification. Concentrations of dissolved $\mathrm{N}_{2}$ and $\mathrm{Ar}$ in water from the SAS wells and UFA well 5 were consistent with atmospheric equilibrium of the air during recharge with the addition of small amounts of excess air $\left(<4.8 \mathrm{~cm}^{3} \mathrm{STP} / \mathrm{L}\right)$. Apparent ground water recharge temperatures ranged from $14.0^{\circ} \mathrm{C}$ to $22.7^{\circ} \mathrm{C}$ in the SAS wells and from 20.3 to $22.2^{\circ} \mathrm{C}$ in UFA well 5 . The wide variation in apparent recharge temperatures from the SAS wells likely resulted from the seasonal temperature fluctuations of the treated effluent discharged to the RIBS combined with the high infiltration rate. Apparent recharge temperatures were anomalously high in UFA wells $2\left(30.1-36.9^{\circ} \mathrm{C}\right), 3\left(36.8-37.8^{\circ} \mathrm{C}\right)$, and 4 $\left(30.2-33.9^{\circ} \mathrm{C}\right)$, and were near or slightly higher than the mean annual air temperature in well $1-\mathrm{E}\left(21.5-25.4^{\circ} \mathrm{C}\right)$. It was interpreted from these high recharge temperatures there was another source of $\mathrm{N}_{2}$ in the ground water besides recharge water in equilibrium with atmospheric air and the entrainment of excess air. This additional source of $\mathrm{N}_{2}$ most likely resulted from the denitrification of $\mathrm{NO}_{3}{ }^{-}$. The amount of $\mathrm{N}_{2}$ resulting from denitrification was estimated to range from near zero to $4.8 \mathrm{mg} / \mathrm{L}$, assuming the water in these wells was recharged at the median recharge temperature calculated for well $5\left(21.4^{\circ} \mathrm{C}\right)$, which is close to the mean annual air temperature for the area. Concentrations were lowest in well 1-E (near zero to $1.5 \mathrm{mg} / \mathrm{L})$ and highest in wells $2(2.8-4.6 \mathrm{mg} / \mathrm{L})$ and $3(4.7-4.8 \mathrm{mg} / \mathrm{L})$. The amount of excess $\mathrm{N}_{2}$ may be underestimated for well 1-E. Water may be recharged to this well at a temperature similar to those determined for the SAS wells $\left(14.0^{\circ} \mathrm{C}\right.$ to $\left.22.7^{\circ} \mathrm{C}\right)$. A lower recharge temperature would result in a higher estimate of the amount of $\mathrm{N}_{2}$ resulting from denitrification, and would range from $2.7-4.1 \mathrm{mg} / \mathrm{L}$ at $15^{\circ} \mathrm{C}$ and $1.4-2.8 \mathrm{mg} / \mathrm{L}$ at $18^{\circ} \mathrm{C}$.

Elevated $\delta^{15} \mathrm{~N}$ of $\mathrm{N}_{2}$ values measured in wells $1-\mathrm{E}$ and 2-4 confirmed denitrification had occurred in these UFA wells. $\delta^{15} \mathrm{~N}$ of $\mathrm{N}_{2}$ values in wells $1-\mathrm{E}$ and $2-4(+0.94$ to $+2.14 \%$ ) were notably higher than values associated with air-saturated water, approximately $+0.75 \%$. $\delta^{15} \mathrm{~N}$ of $\mathrm{N}_{2}$ values in the SAS wells ( +0.61 to $+0.75 \%$ ) and UFA well 5 ( +0.70 to $+0.84 \%$ ) were similar to air-saturated water values. The isotopic enrichment associated with denitrification was estimated to range from -2 to $-8 \%$, which generally is smaller compared to the ranges reported for denitrification (Kendall and Aravena, 2000). Smaller enrichment factors reported in this study likely resulted from the well water samples containing a mixture of denitrified and undenitrified waters.

Detections of $\mathrm{N}_{2} \mathrm{O}$ and $\mathrm{NO}_{2}{ }^{-}$indicated active denitrification occurred in selected parts of the UFA. $\mathrm{N}_{2} \mathrm{O}$ and $\mathrm{NO}_{2}{ }^{-}-\mathrm{N}$ were detected in water samples from two UFA wells, 1-E and 4. $\mathrm{N}_{2} \mathrm{O}$ concentrations in well 1-E ranged from $20.4-25.7 \mu \mathrm{g} / \mathrm{L}$, and $\mathrm{NO}_{2}{ }^{-}$concentrations in this well ranged from below method reporting limits $(0.008 \mathrm{mg} / \mathrm{L}$ as $\mathrm{N})$ to $0.04 \mathrm{mg} / \mathrm{L}$ as $\mathrm{N}$. $\mathrm{N}_{2} \mathrm{O}$ concentrations were lower in well 4 compared to well 1-E and ranged from 3.1-11.9 $\mu \mathrm{g} / \mathrm{L}$, and $\mathrm{NO}_{2}{ }^{-}$concentrations in this well ranged from below method reporting limits $(0.016$ $\mathrm{mg} / \mathrm{L}$ as $\mathrm{N}$ ) to $0.04 \mathrm{mg} / \mathrm{L}$ as $\mathrm{N}$. $\mathrm{N}_{2} \mathrm{O}$ also was detected in SAS wells $1-\mathrm{B}, 1-\mathrm{C}$, and 1-D at concentrations ranging from 3.1-20.2 $\mu \mathrm{g} / \mathrm{L}$, although the highest concentrations were measured in well 1-D (16.6-20.0 $\mu \mathrm{g} / \mathrm{L})$. These $\mathrm{N}_{2} \mathrm{O}$ detections may have resulted from: 1$)$ the initial onset of denitrification before any appreciable build-up of $\mathrm{N}_{2}$ in the ground water because some $\mathrm{O}_{2}$ concentrations measured were near the upper limit for ground waters exhibiting evidence for denitrification, and $\delta^{15} \mathrm{~N}$ of $\mathrm{N}_{2}$ values were similar to those in airsaturated water, 2) the water in the well contains a mixture of denitrified and nondenitrified waters, or 3) nitrification of ammonium in the ground water. However, ammonium only was 
detected at concentrations near method detection limits in the water from these wells (0.01 $\mathrm{mg} / \mathrm{L}$ ), which is considerably lower than concentrations previously reported in ground water in which nitrification was occurring (Smith et. al., 2006). This suggests the potential for nitrification in the SAS may be limited.

\section{Sources of Nitrate and Initial Nitrate Concentrations}

Measured $\delta^{15} \mathrm{~N}$ of $\mathrm{NO}_{3}{ }^{-}$and $\delta^{18} \mathrm{O}$ of $\mathrm{NO}_{3}{ }^{-}$values indicated that the source of nitrate was treated effluent in the SAS. $\delta^{15} \mathrm{~N}$ of $\mathrm{NO}_{3}{ }^{-}$and $\delta^{18} \mathrm{O}$ of $\mathrm{NO}_{3}{ }^{-}$values in water from these wells were consistent with values measured in the effluent and were within the typical range of values in wastewater (Fig. 3). Elevated boron concentrations also indicated the source of the high nitrate concentrations in the SAS wells was treated wastewater. Boron is a common component of detergents and often is used as a tracer of wastewater in ground water systems (Repert et. al., 2006; Verstraeten et. al., 2005). Boron concentrations measured in the SAS wells ranged from $0.17-0.23 \mathrm{mg} / \mathrm{L}$ and were slightly lower than those measured in the treated effluent.

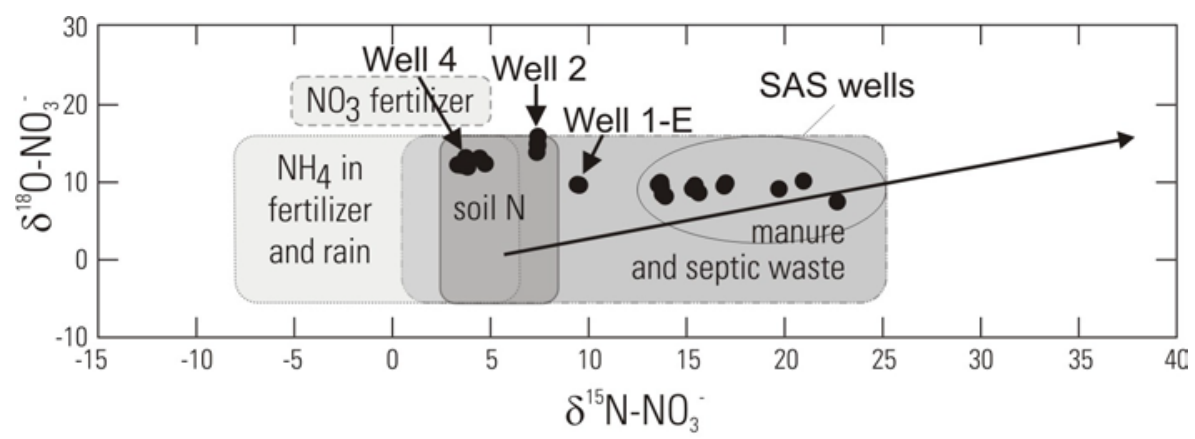

Figure 3. $\delta^{15} \mathrm{~N}$ and $\delta^{18} \mathrm{O}$ of $\mathrm{NO}_{3}$ values from SAS wells and UFA wells $1-E, 2$, and 4 and typical ranges of values. Values for UFA wells represent the initial isotopic composition and were calculated assuming a recharge temperature of $21.4^{\circ} \mathrm{C}$ for wells 2 and 4 and $18^{\circ} \mathrm{C}$ for well 1-E. Typical ranges of values were from Kendall and Aravena, 2000.

Reconstructed initial $\mathrm{N}$ isotope values indicated that treated wastewater and fertilizer were the $\mathrm{NO}_{3}{ }^{-}$sources in the UFA wells. Estimated initial nitrate concentrations in the UFA wells ranged from 2.58-6.77 mg/L, depending upon the recharge temperature assumed for well 1-E. Initial nitrate concentrations in wells 2-4 ranged from 3.10-4.82 mg/L. In well 1-E, the initial nitrate concentrations ranged from $2.58-3.67 \mathrm{mg} / \mathrm{L}$ as $\mathrm{N}$ if the assumed recharge temperature was $21.4^{\circ} \mathrm{C}$ and was higher for lower assumed recharge temperatures (for example $5.77-6.77 \mathrm{mg} / \mathrm{L}$ as $\mathrm{N}$ at a recharge temperature of $\left.15^{\circ} \mathrm{C}\right) . \delta^{15} \mathrm{~N}$ of $\mathrm{NO}_{3}^{-0}$ values were estimated for three UFA wells: 1-E, 2, and $4 . \delta^{15} \mathrm{~N}$ of $\mathrm{NO}_{3}{ }^{-0}$ values could not be estimated for wells 3 and 5 because there was insufficient $\mathrm{NO}_{3}{ }^{-}$in water samples to determine its current isotopic composition. $\delta^{15} \mathrm{~N}$ of $\mathrm{NO}_{3}{ }^{-0}$ values in wells 1-E and 2 (Fig. 3), which are located near two of the most heavily-loaded RIBS, indicated the nitrate source likely was treated wastewater. Lower $\delta^{15} \mathrm{~N}$ of $\mathrm{NO}_{3}^{-{ }^{-0}}$ values in well 4 indicated the nitrate source was past 
fertilizer use, which may have originated from citrus agriculture. The distribution of boron concentrations in the UFA wells supports this interpretation of the isotope data. The highest boron concentrations in the UFA were measured in wells 1-E $(0.06-0.10 \mathrm{mg} / \mathrm{L})$ and $2(0.06-$ $0.08 \mathrm{mg} / \mathrm{L}$ ), and concentrations in the other UFA wells ranged from $0.01-0.03 \mathrm{mg} / \mathrm{L}$.

\section{Summary and Conclusions}

The potential for denitrification and sources of nitrate were evaluated in the karstic Upper Floridan aquifer (UFA) and overlying surficial aquifer beneath and upgradient from a wastewater treatment and reuse facility in Central Florida. Prior to the construction of this facility, the land use likely was citrus agriculture. Nitrate-N concentration $(<0.02$ to 6.3 $\mathrm{mg} / \mathrm{L}$ ) in ground water in this area likely originated from past fertilizer use in citrus agriculture or treated wastewater applied to rapid-sand infiltration beds. Chemical, isotopic, and dissolved gas data were evaluated from water samples collected from 9 wells to determine nitrate sources, the potential for denitrification, and identify areas of active denitrification. Sampled surficial aquifer wells ranged from 3.7 to $23.8 \mathrm{~m}$ deep, and UFA wells ranged from 46 to $102 \mathrm{~m}$ deep. $\delta^{15} \mathrm{~N}$ of $\mathrm{NO}_{3}{ }^{-}$and $\delta^{18} \mathrm{O}$ of $\mathrm{NO}_{3}{ }^{-}$values in well water samples indicated that treated wastewater likely is the source of nitrate in the surficial aquifer wells, whereas reconstructed initial $\delta^{15} \mathrm{~N}_{\text {of }} \mathrm{NO}_{3}{ }^{-}$values indicated the sources of nitrate in the UFA were treated wastewater in wells closest to the RIBS and fertilizer in the well located further away from the facility. Denitrification likely occurs in the UFA, but may only occur to a limited extent in the surficial aquifer. Dissolved oxygen concentrations generally were less than $1 \mathrm{mg} / \mathrm{L}$ in the UFA and greater than $2 \mathrm{mg} / \mathrm{L}$ in the surficial aquifer. Dissolved gas and isotopic data indicated that denitrification had occurred in water from 4 of 5 UFA wells. Excess nitrogen gas $\left(\mathrm{N}_{2}\right)$, the end product of denitrification, was estimated to be present in water from four UFA wells based on the concentrations of dissolved $\mathrm{N}_{2}$ and $\mathrm{Ar}$ in the ground water. Excess $\mathrm{N}_{2}$ concentrations which likely resulted from denitrification typically ranged from 1 to $5 \mathrm{mg} / \mathrm{L}$. $\delta^{15} \mathrm{~N}$ values associated with $\mathrm{N}_{2}$ in these same wells also were substantially greater ( +0.97 to $+2.14 \%$ o) than for $\mathrm{N}_{2}$ in equilibrium with air-saturated water. Denitrification may naturally attenuate some nitrate in low dissolved oxygen zones of the UFA before it is transported to natural springs in the area. The chemical character of groundwater in karst can change rapidly during recharge events (Doctor et al., 2006). More frequent sampling of well water during conditions of water table fluctuation, especially during periods of RIB loading, may provide additional information on controls on conditions leading to denitrification within the study area.

\section{Acknowledgments}

This study was funded jointly by the US Geological Survey (USGS) and Orange County, Florida. The author greatly appreciates the permission given by the Orlando-Orange County Expressway Authority to sample water from their private well. The author thanks J.K. Böhlke and Dick Smith of the USGS for analysis of stable isotopes of aqueous $\mathrm{N}_{2}$, allowing the author to use laboratory equipment to analyze $\mathrm{N}_{2} \mathrm{O}$ in water samples, and insightful discussions. Field assistance from Orange County and Trudy Phelps of the USGS is 
gratefully acknowledged. The manuscript was significantly improved from reviews from Dan Doctor and Lan Tornes of the USGS.

\section{References}

Adamski, J.C., and E.R. German, 2004, Hydrogeology and quality of ground water in Orange County, Florida: USGS Water-Resources Investigations Report 03-4257.

Aulenbach, D.B., and T.J. Tofflemire, Thirty-five years of continuous discharge of secondary treated effluent onto sand beds: Ground Water, v. 13, no. 2, p. 161-166.

Böhlke, J.K., and T.B. Coplen, 1995, Interlaboratory comparison of secondary reference materials for nitrogen-isotope-ratio measurements, in Reference and intercomparison materials for stable isotopes of light elements: Vienna, Austria, International Atomic Energy Agency, IAEA-TECDOC-825, p. 51-66.

Böhlke, J.K., R. Wanty, M. Tuttle, G. Delin, and M. Landon, 2002, Denitrification in the recharge area and discharge area of a transient agricultural nitrate plume in a glacial outwash sand aquifer, Minnesota: Water Resources Research, v. 38, 10.1029/2001/WR000663.

Brooke, C.J., and V.J. Godlewski, 1995, Water reuse in Orange County: Florida Water Resources Journal, August 1995, p. 26-28.

Busenberg, E., Plummer, L.N., Bartholomay, R.C., and J.E. Wayland, 1998, Chlorofluorocarbons, sulfur hexafluoride, and dissolved permanent gases in ground water from selected sites in and near the Idaho National Engineering and Environmental Laboratory, Idaho, 1997-97: USGS Open-File Report 98-274.

Casciotti, K.L., Sigman, D.M., Hastings, M., Böhlke, J.K., and A. Hilkert, 2002, Measurement of the oxygen isotopic composition of nitrate in seawater and freshwater using the denitrifier method: Analytical Chemistry, v. 74, p. 4905-4912.

Coplen, T. B., 1988, Normalization of oxygen and hydrogen isotope data: Chemical Geology (Isotope Geoscience Section), v. 72, p. 293-297.

Coplen, T. B., 1994, Reporting of stable hydrogen, carbon, and oxygen isotopic abundances: Pure and Applied Chemistry, v. 66, p. 273-276.

Coplen, T.B., Böhlke, J.K., and K. Casciotti., 2004, Using dual-bacterial denitrification to improve delta-15N determinations of nitrates containing mass-independent 17-O: Rapid Communications in Mass Spectrometry, v. 18, p. 245-250.

Coxon, C., 1999, Agriculturally induced impacts, In Karst Hydrogeology and Human Activities-Impacts, Consequences, and Implications, ed. D. Drew, and H. Hötzel, p. 37-80, A.A. Balkema Publishers. 
Doctor, D.H., Alexander, E.C., Jr., Petric, M., Kogovsek, J., Urbanc, J., Lojen, S., and Stichler, W., 2006, Quantification of karst aquifer discharge components through endmember mixing analysis using natural chemistry and stable isotopes as tracers: Hydrogeology Journal, v. 14, p. 1171-1191.

Fishman, M.J., ed., 1993, Methods of analysis by the U.S. Geological Survey National Water Quality Laboratory--Determination of inorganic and organic constituents in water and fluvial sediments: U.S. Geological Survey Open-File Report 93-125, 217 p.

Florida Department of Environmental Protection, 2004, A strategy for water quality protection: Wastewater treatment in the Wekiva Study Area: Tallahassee, Florida.

Kendall, C., and R. Aravena, 2000, Nitrate isotopes in ground water systems, in Cook. P.G. and A.L. Herczeg (eds.), Environmental Tracers in Subsurface Hydrology, Kluwer Academic Publishers, p. 261-297.

Kinnaman, S.L., 2006, Potentiometric surface of the Upper Floridan aquifer in the St. Johns River Water Management District and vicinity, September 2005: U.S. Geological Survey Open-File Report 2006-1108, 1 sheet.

Korom, S.F., 1992, Natural denitification in the saturated zone-A review: Water Resources Research, v. 28, p. 1657-1668.

LeBlanc, D.R., 1984, Sewage plume in a sand and gravel aquifer, Cape Cod, Massachusetts: U.S. Geological Survey Water-Supply Paper 2218.

Marella, R.L., 2004, Water withdrawls, use, discharge, and trends in Florida, 2000: U.S. Geological Survey Scientific Investigations Report 2004-5151.

Mariotti, A., 1983, Atmospheric nitrogen is a reliable standard for natural $15 \mathrm{~N}$ abundance measurements: Nature, v. 303, p. 685-687.

Mariotti, A., A. Landreau, and B. Simon, 1988, $15 N$ isotope biogeochemistry and natural denitrification process in ground water: application to the Chalk aquifer of Northern France: Geochimica et Cosmochimica Acta, v. 52, p. 1869-1878.

Morrell, R.A., MacIntyre, D., Teegarden, R., and G. Delneky, 2002, Effluent disposal and water supply coming together at Orange County's Northwest Water Reclamation Facility: Florida Water Resources Journal, March 2002, p. 41-44.

O’Reilly, A.M., 1998, Hydrogeology and simulation of the effects of reclaimed water application in West Orange and Southeast Lake Counties, Florida: USGS Water-Resources Investigations Report 97-4199.

Panno, S.V., K.C. Hackley, H.H. Hwang, and W.R. Kelly, 2001, Determination of the sources of nitrate contamination in karst springs using isotopic and chemical indicators: Chemical Geology, v. 179, p. 113-128. 
Post Buckley Schuh \& Jernigan, Inc., 1993, Hydraulic capacity analysis of existing infiltration basins-Orange County Northwest Water Reclamation Facility: Winter Park, Florida.

Repert, D.A., L.B. Barber, K.M. Hess, S.H. Keefe, D.B. Kent, D.R. LeBlanc, and R.L. Smith, 2006, Long-tern natural attenuation of carbon and nitrogen within a ground water plume after removal of the treated wastewater source: Environmental Science and Technology, v. 40, p. 1154-1162.

Revesz, K., Böhlke, J.K., Smith, R.L., and Yoshinari, T., 1999, Stable isotope composition of dissolved $\mathrm{O} 2$ undergoing respiration in a ground-water contamination gradient: U.S. Geological Survey Water-Resources Investigations Report 99-4018C, p. 323-328, http://pubs.er.usgs.gov/usgspubs/wri/wri994018C.

Revesz, K., and K. Casciotti, 2005, Nitrogen and oxygen isotope ratio analysis of dissolved nitrate by the denitrifier method using continuous flow isotope ratio mass spectrometry: Standard Operation Procedure (SOP) \#2900. Techniques of the U. S. Geological Survey, in preparation.

Sigman, D.M., K.L. Casciotti, M. Andreani, C. Barford, M.Galanter, and J.K. Böhlke, 2001, A bacterial method for the nitrogen isotopic analysis of nitrate in seawater and freshwater: Analytical Chemistry, v. 73, p. 4145-4153.

St. Johns River Water Management District, 2006a, District water supply plan 2005: St. Johns River Water Management District Technical Publication SJ2006-2, Palatka, Florida.

St. Johns River Water Management District, 2000b, Water supply assessment-2003: St. Johns River Water Management District Technical Publication SJ2006-1, Palatka, Florida.

Smith, R.L., and J.H. Duff, 1988, Denitrification in a sand and gravel aquifer: Applied and Environmental Microbiology, v. 54, p. 1071-1078.

Smith, R.L., L.K. Baumgartner, D.N. Miller, D.A. Repert, and J.K. Bohlke, 2006, Assessment of nitrification potential in ground water using short term, single-well injection experiments: Microbial Ecology, v. 51, p. 22-35.

Smith, L.K., M.A.Voytek, J.K. Böhlke, and J.W. Harvey, 2006, Denitrification in nitraterich streams: application of $\mathrm{N} 2-\mathrm{Ar}$ and $15 \mathrm{~N}$-tracer methods in intact cores: Ecological Applications (in press).

Spechler, R.M., and K.J. Halford, 2001, Hydrogeology, water quality and simulated effects of ground-water withdrawls from the Floridan aquifer system, Seminole County and vicinity, Florida: USGS Water-Resources Investigations Report 01-4182. 
Starr, R.C., and R.W. Gillham, 1993, Denitrification and organic carbon availability in two aquifers: Ground Water, v. 31, p. 934-946.

Stevenson, R.J., A. Pinowska, and Y. Wang, 2004, Ecological condition of algae and nutrients in Florida Springs: Report submitted to the Florida Department of Environmental Protection, Tallahassee, Florida.

U.S. Environmental Protection Agency, 2004, Guidelines for water reuse: USEPA Report EPA/625/R-04/108.

Verstraeten, I.M., G.S. Fetterman, M.T. Meyer, T. Bullen, and S.K. Sebree, 2005, Use of tracers and isotopes to evaluate vulnerability of water in domestic wells to septic waste: Ground Water Monitoring and Remediation, v. 25, p. 107-117.

Wassenaar, L.I., 1995, Evaluation of the origin and fate of nitrate in the Abbotsford aquifer using the isotopes of ${ }^{15} \mathrm{~N}$ and ${ }^{18} \mathrm{O}$ in $\mathrm{NO}_{3}{ }^{-}$: Applied Geochemistry, v. 10, p. 391-405.

Wilde, F.D.; D.B. Radtke, J. Gibs, R.T Iwatsubo (eds.), 1999, National field manual for the collection of water-quality data-Collection of Water Samples: U.S. Geological Survey Techniques of Water Resources Investigations Report 09-A4.

Williams, P.W. (ed.), 1993, Karst terrains-Environmental changes and human impact: Catena Supplement 25, 268 p.

Wilson, G.B., J.N. Andrews, and A.H., Bath, 1990, Dissolved gas evidence for denitrification in the Lincolnshire limestone ground waters, eastern England: Journal of Hydrology, vol. 113, p. 51-60.

York, D.W.; L. Walker-Coleman, and C. Ferraro, 2002, Florida's water reuse programpast, present, and future directions: Proceedings of Symposium XVII, Water Reuse Association, Orlando, Florida.

\section{Biographical Sketch}

Sharon Kroening is a hydrologist with the U.S. Geological Survey in Orlando, Florida; U.S. Geological Survey, 12986 Research Parkway, Orlando, Florida 32826; kroening@usgs.gov. 


\section{Appendix 2. Laboratory Report of Tritium/He Measurements for USGS Project}

Prepared by the Noble Gas Laboratory Lamont-Doherty Earth Observatory of Columbia University, New York. Explanatory information provided for the reader precedes the reprinted document. Refer to Schlosser and others (2008) in the references cited section for the complete report citation. 
Tritium/helium measurements may be used to determine the elapsed time since water in an aquifer lost contact with the atmosphere, commonly referred to as the "age" of the water. Tritium is a radioactive form of hydrogen containing 1 proton and 2 neutrons, often written as ${ }^{3} \mathrm{H}$. Tritium is a rare, naturally occurring isotope with typical concentrations near 1-3 tritium units (TU) in current rain samples. From 1952 to 1963, tritium was also produced as a byproduct of above ground testing of nuclear bombs. Tritium is incorporated into the water molecule, making it an effective environmental tracer that is useful in age dating relatively young groundwater. Tritium concentrations peaked in 1963 at over 1,000 TU in precipitation at some locations in the U.S. In Miami from the mid-1960s to 1990, the tritium concentration in precipitation ranged from 35 TU to the background concentration of 1-3 TU (Walsh and Price, 2010).

The half-life of tritium is 12.43 years (Unterwegar and others, 1980) and the end product is radioactive helium, ${ }^{3} \mathrm{He}_{\text {trit }}$ (Turrin, 2012). As a result of radioactive decay since the peak production of tritium, an accurate measurement of the concentration of ${ }^{3} \mathrm{He}_{\text {trit }}$ is also required to estimate groundwater age. Helium is predominately in the form of ${ }^{4} \mathrm{He}$, but ${ }^{3} \mathrm{He}$ is naturally occurring in the earth's mantle and the atmosphere. In order to determine the precise concentration of ${ }^{3} \mathrm{He}_{\text {trit }}$ in groundwater, the following variables need to be accounted for: concentrations of ${ }^{4} \mathrm{He}$ and neon dissolved in groundwater and the temperature and elevation at which recharging water was no longer in equilibrium with the atmosphere (Turrin, 2012). For further detail on ${ }^{3} \mathrm{H} /{ }^{3} \mathrm{He}$ dating methods, see Schlosser and others (1988).

The nine water samples presented in this lab report were collected to determine the age of water in the surficial and Upper Floridan aquifer from wells located at or near the Northwest Water Reclamation Facility in Orange County, Florida (fig. 1). Not all of these results are included in the main report because some analyses were inconclusive or not used for the study. Description of well depths and location reported by Kroening (2007) are included in appendix I; however, the well names were different in that report. Cluster wells 1-B, 1-C, 1-D in Kroening (2007) are reported in this appendix as Cluster Well 2, Cluster Well 3, and Cluster Well 4, respectively. Cluster Well 1-E in Kroening (2007) is Monitoring Well 8R, and sites 2, 3, 4, and 5 are reported here as Monitoring Well 2, Monitoring Well 5R, Phipps Well and Toll Plaza Well, respectively. Keene Road Well 14, which was not used in this study, is an Upper Floridan Well located in the landfill on the northeast boundary of the RIBs site. This well is $172 \mathrm{ft}$ deep with a $10 \mathrm{ft}$ open interval. Three wells are in the surficial aquifer and the remaining 6 wells are in the Upper Floridan aquifer. Information on well depths, casing, and hydrogeology are in Kroening (2007) under Site Selection.

The wells were sampled January 24, 25, 31 of 2006, using the method described by Schlosser (undated). Nine sets of duplicate samples were submitted to the laboratory. Analysis methodology is described by Schlosser and others (1988). Laboratory results and measured concentrations are listed in this appendix. For further explanation of the meaning of uncorrected age and corrected age data listed in the laboratory report see U.S. Geological Survey (undated). Tritium was measured in samples from all nine wells, and ranged in concentration from 0.08-5.46 TU. The ${ }^{3} \mathrm{He},{ }^{4} \mathrm{He}$, and neon concentrations were measured in the samples from five wells. Neon concentration was also measured in the sample from one additional well. Various reasons are listed in the laboratory report for the possible problems associated with the samples. Two sites where problems affected laboratory analysis were Cluster Well 4 (surficial aquifer) and replicate samples from Monitoring Well 2 (Upper Floridan aquifer). For the purpose of this study, 19 years was used as an estimate for the age of the water from the Upper Floridan aquifer. 


\section{NOBLE GAS LABORATORY \\ LAMONT-DOHERTY EARTH OBSERVATORY OF COLUMBIA UNIVERSITY, NEW YORK}

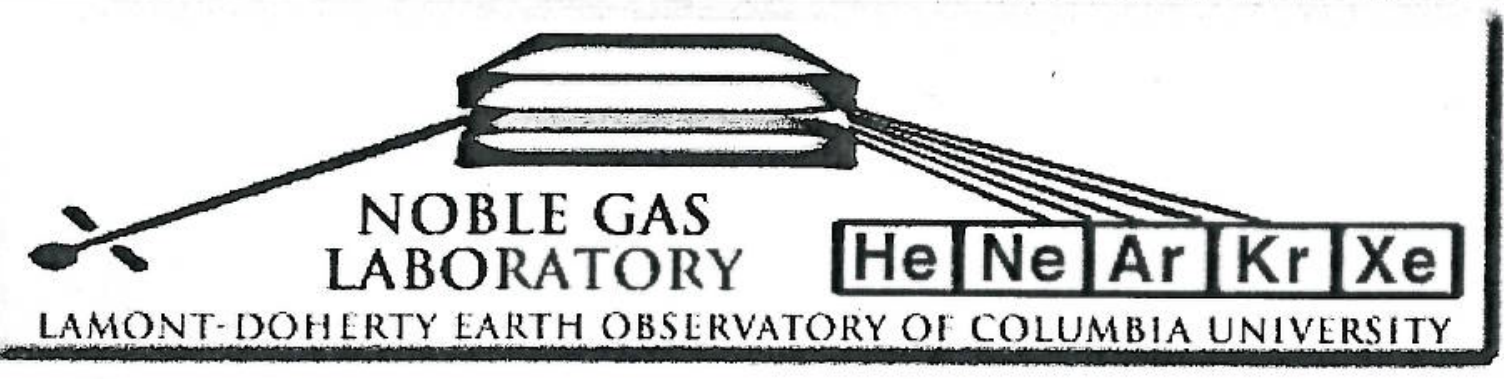

DATA RELEASE NO. 08-1.15.0 (USGS report; 03/24/2008)

TRITIUM/HE MEASUREMENTS FOR THE USGS PROJECT

'Fl-Kroening-1(a)' (SAMPLES SUBMITTED BY Kroening)

Peter Schlosser, Brent D. Turrin, and Millie Klas

Lamont-Doherty Earth Observatory

Palisades, N.Y. 10964 
Data Release No. 08-1.15.0

USGS Data Report 03/24/2008

TRITIUM/HELIUM MEASUREMENTS FOR THE USGS PROJECT:

Fl-Kroening-1(a)

Submitted by Kroening

\section{Data Summary:}

Number of $\mathrm{He} / \mathrm{Ne}$ Samples Submitted in Duplicate 9

Number of $\mathrm{He} / \mathrm{Ne}$ Measurements/Extractions Performed .......................................... 11

Number of He/Ne Data Reported .................................................................... 5

Number of $\mathrm{He} / \mathrm{Ne}$ Samples Re-measured ......................................................... 2

Problems $\quad$ USGS ....................................................................................... 1

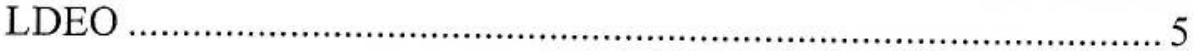

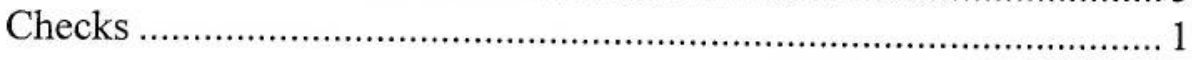

USGS Charge

Number of Samples Measured/Extracted …............................................11-1-5

minus Number of Checks, minus Number of LDEO Problems.......................... 5

Number of Tritium Samples Submitted........................................................... 9

Number of Tritium Measurements Performed.......................................................... 11

Number of Tritium Data Reported .................................................................. 11

Number of Tritium Data Re-measured .............................................................. 3

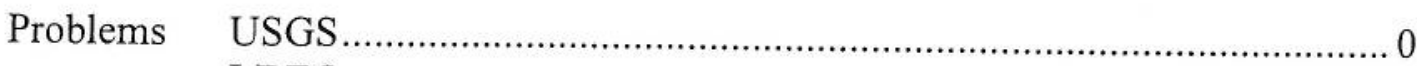

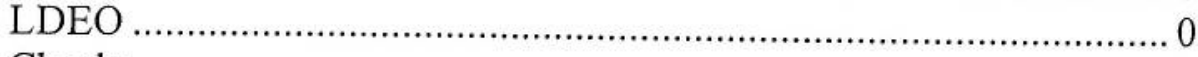

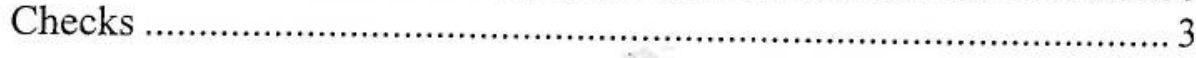

USGS Charge

Number of Samples Measured …........................................................11-3-0

minus Number of Checks, minus Number of LDEO Problems......................... 8

Total Number He/Ne Samples Charged ........................................................... 5

Total Number Tritium Samples Charged.............................................................. 8 


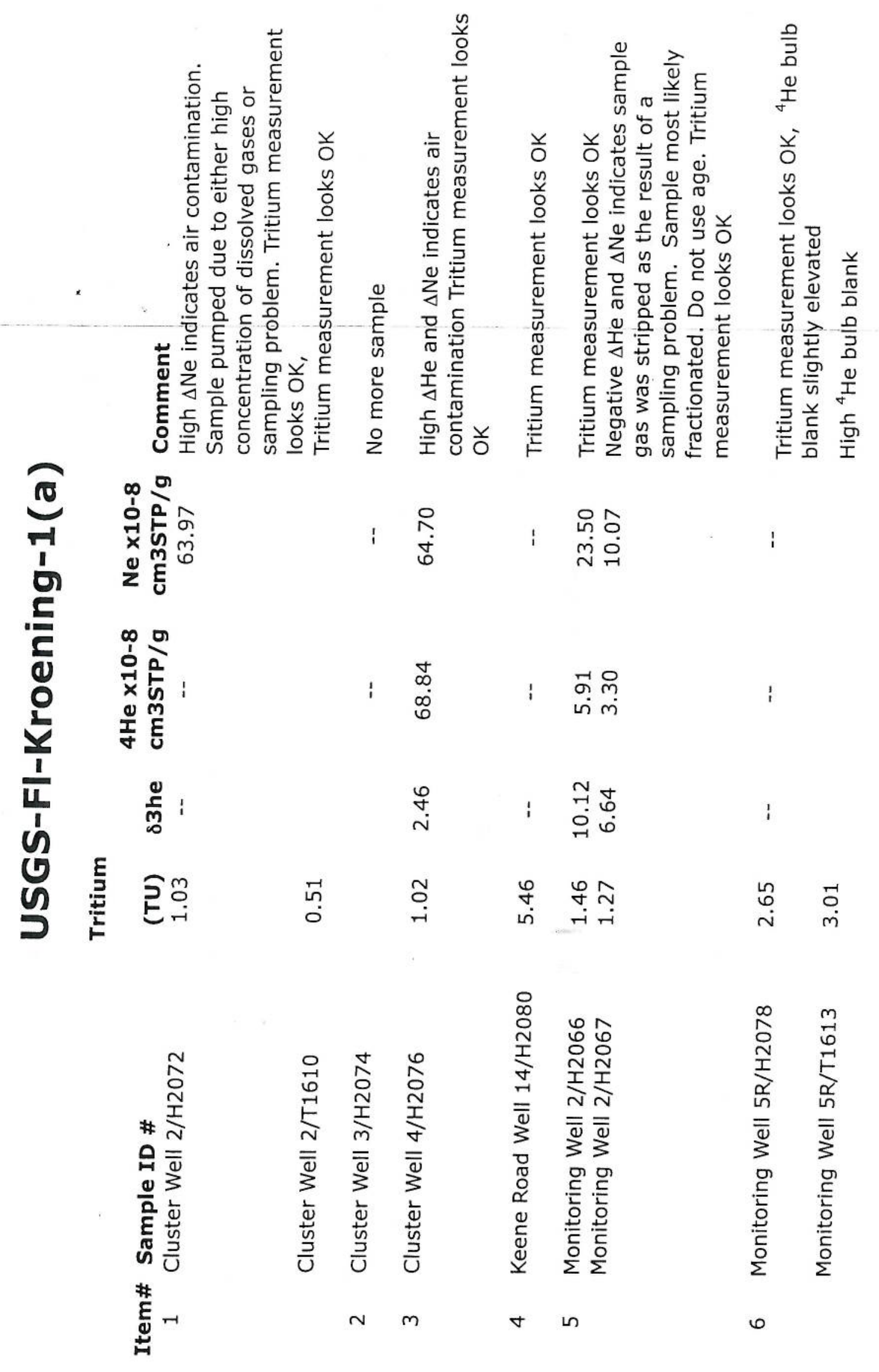




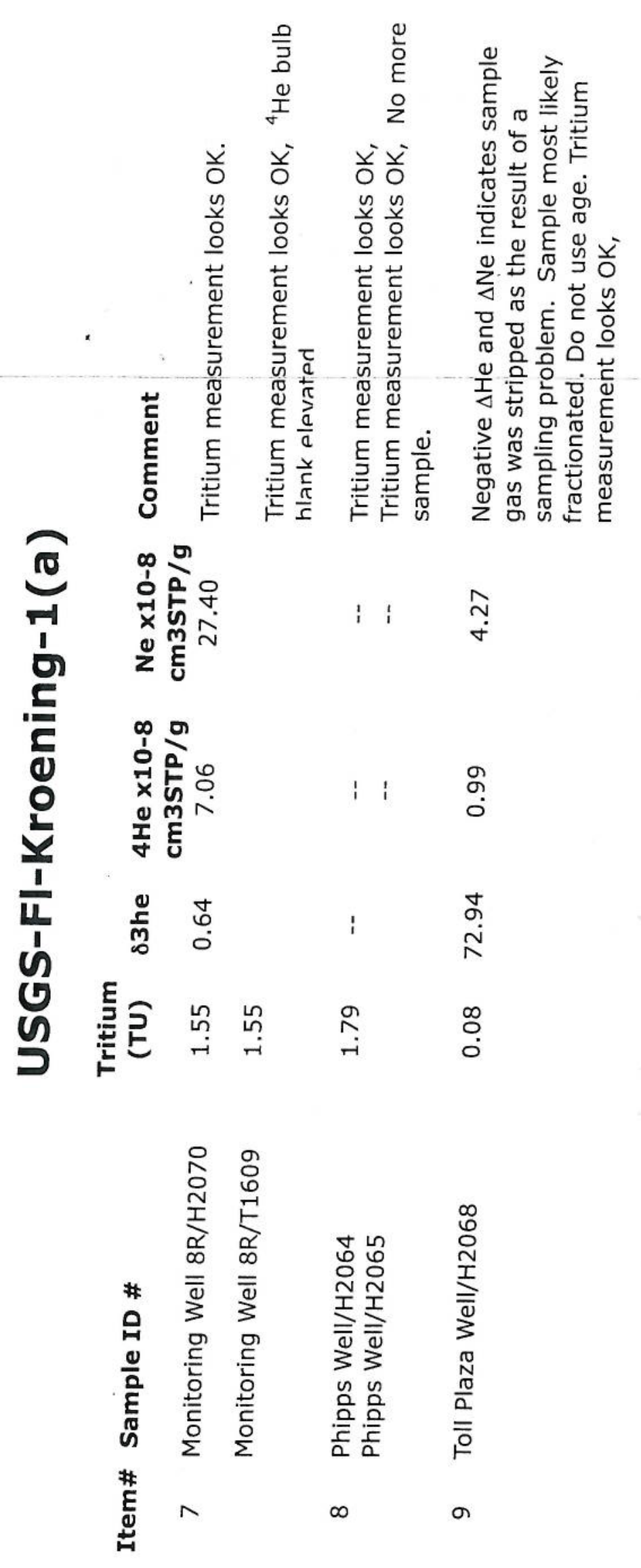



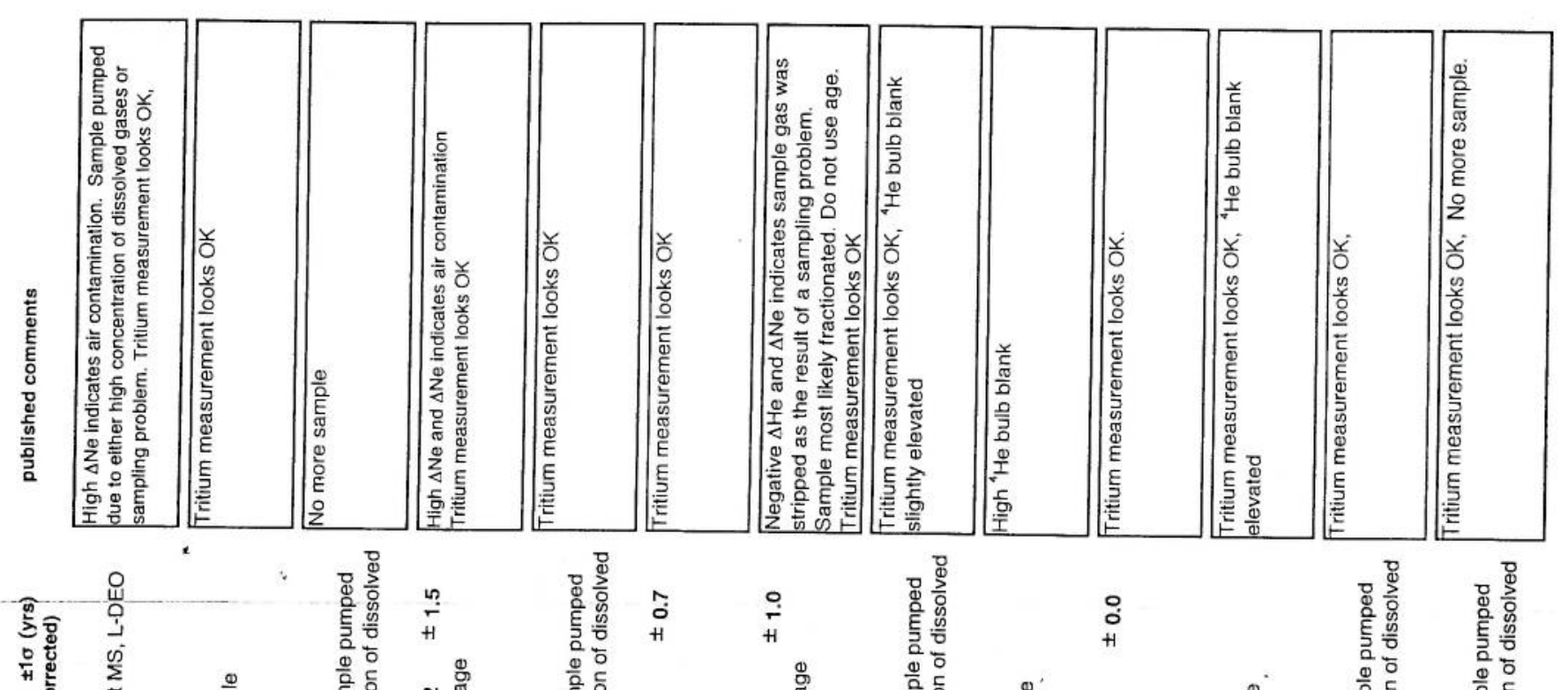

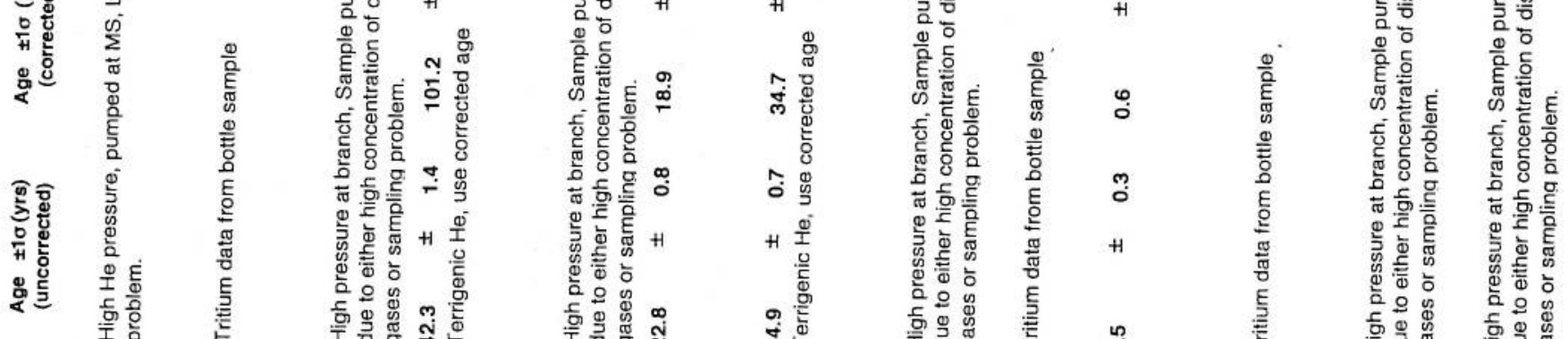
非口日圆日圆圆日圆口日

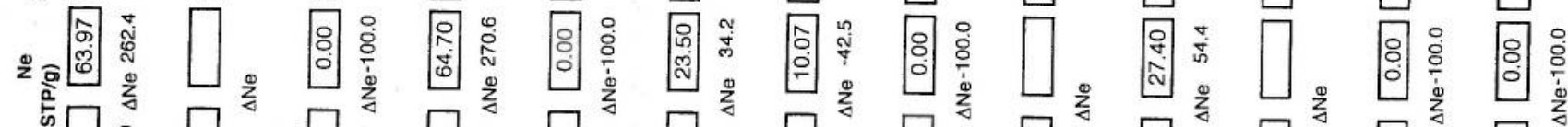

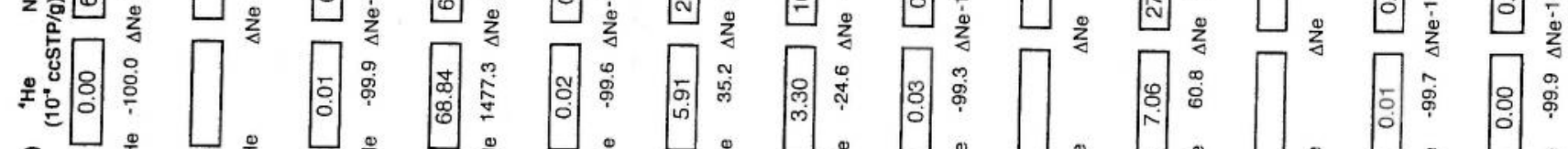

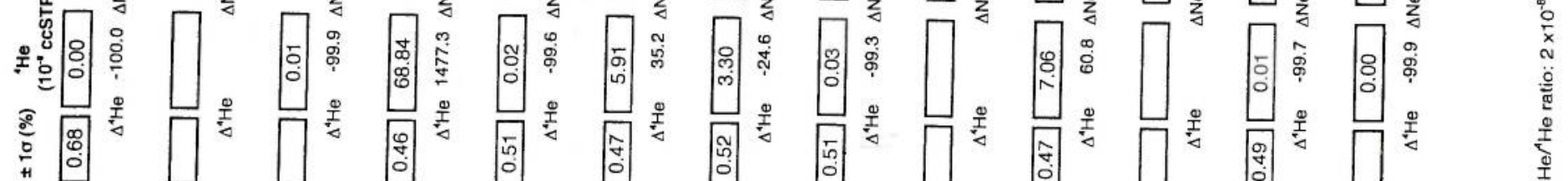

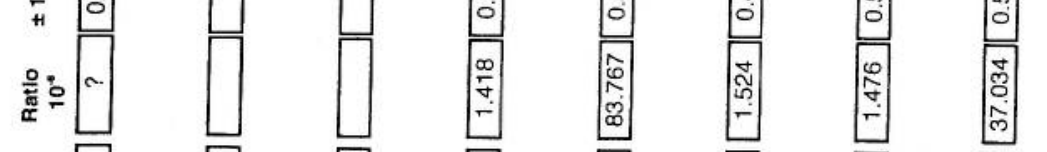
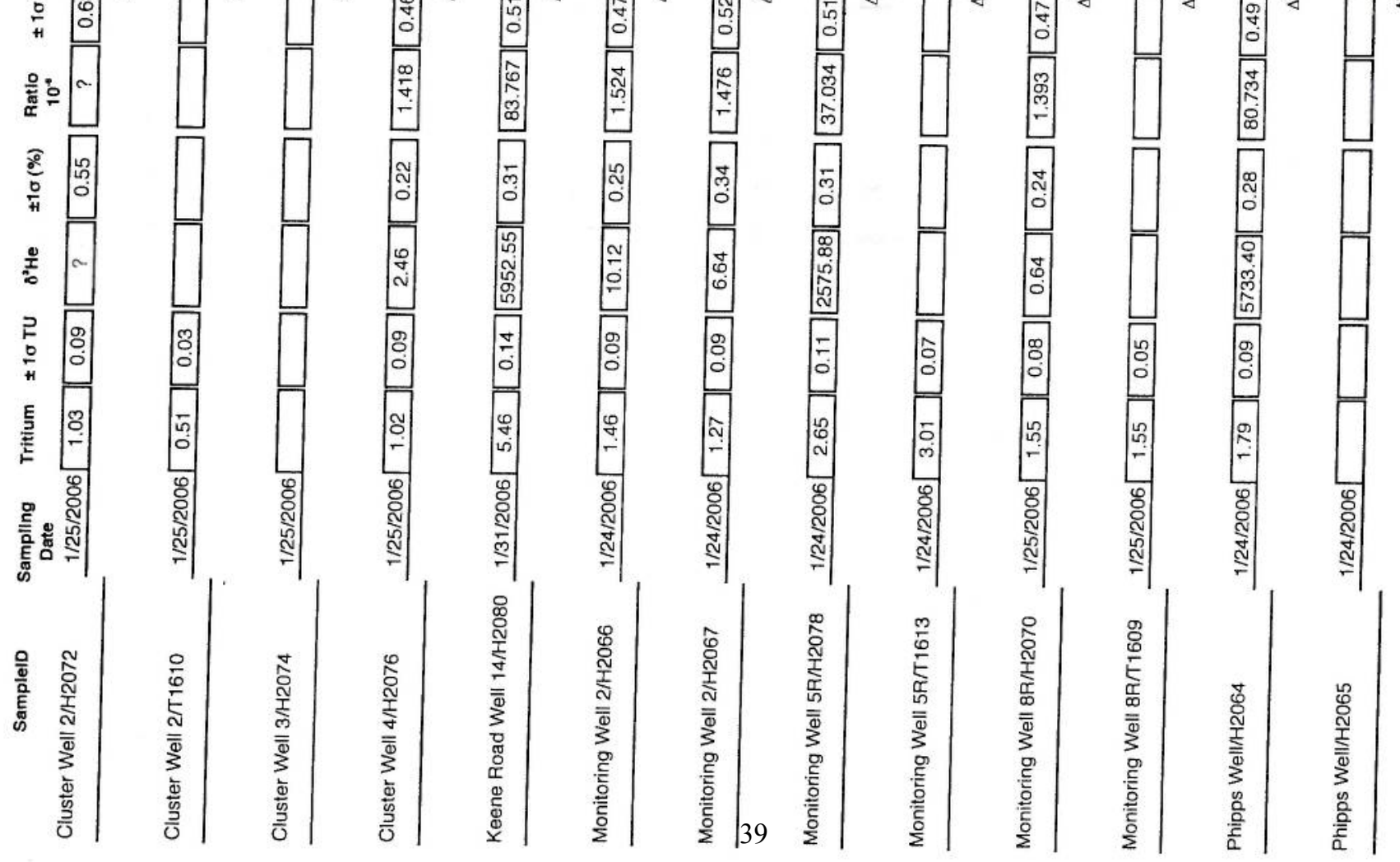


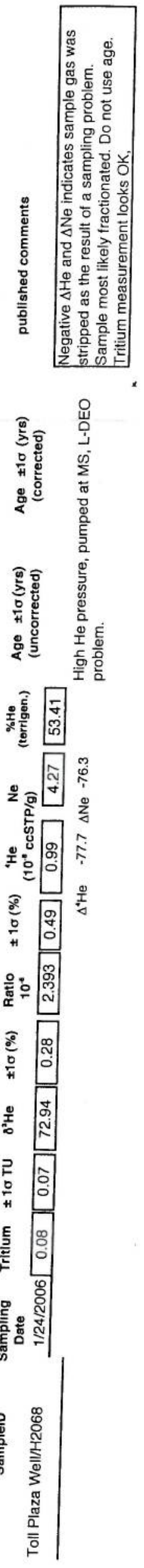




\section{Noble Gas Laboratory Lamont-Doherty Earth Observatory Columbia University, New York}

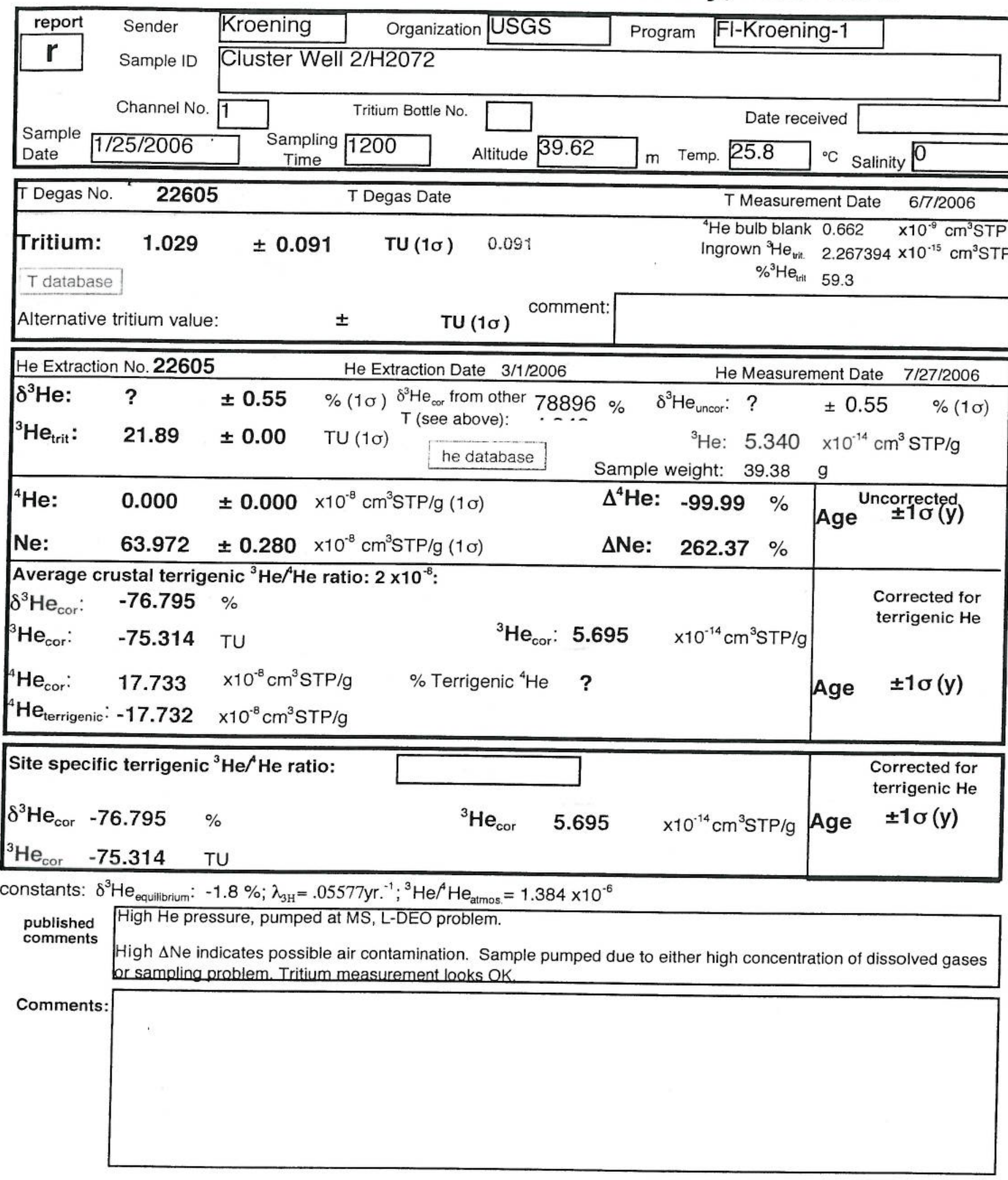




\section{Noble Gas Laboratory Lamont-Doherty Earth Observatory Columbia University, New York}

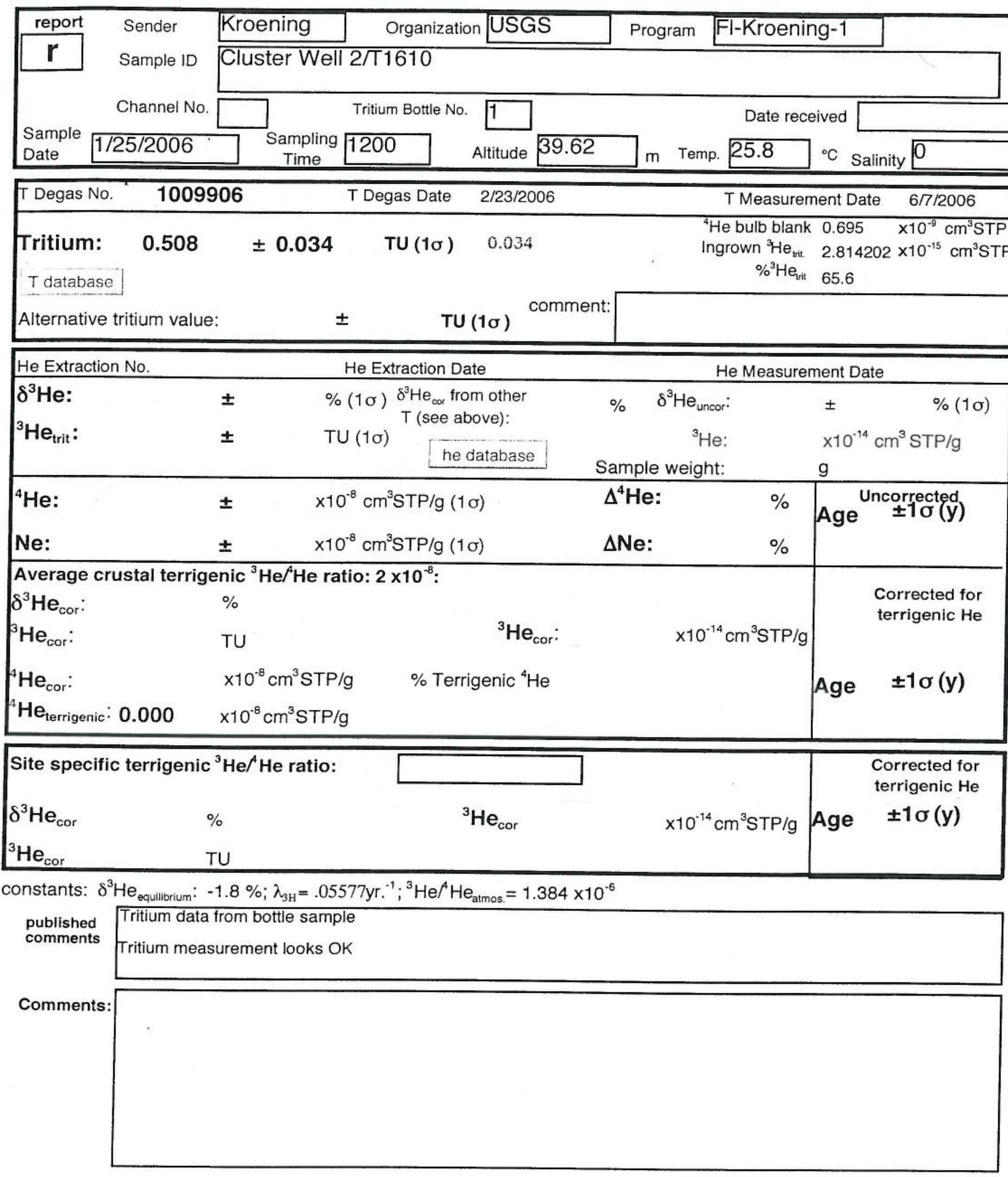




\section{Noble Gas Laboratory Lamont-Doherty Earth Observatory Columbia University, New York}

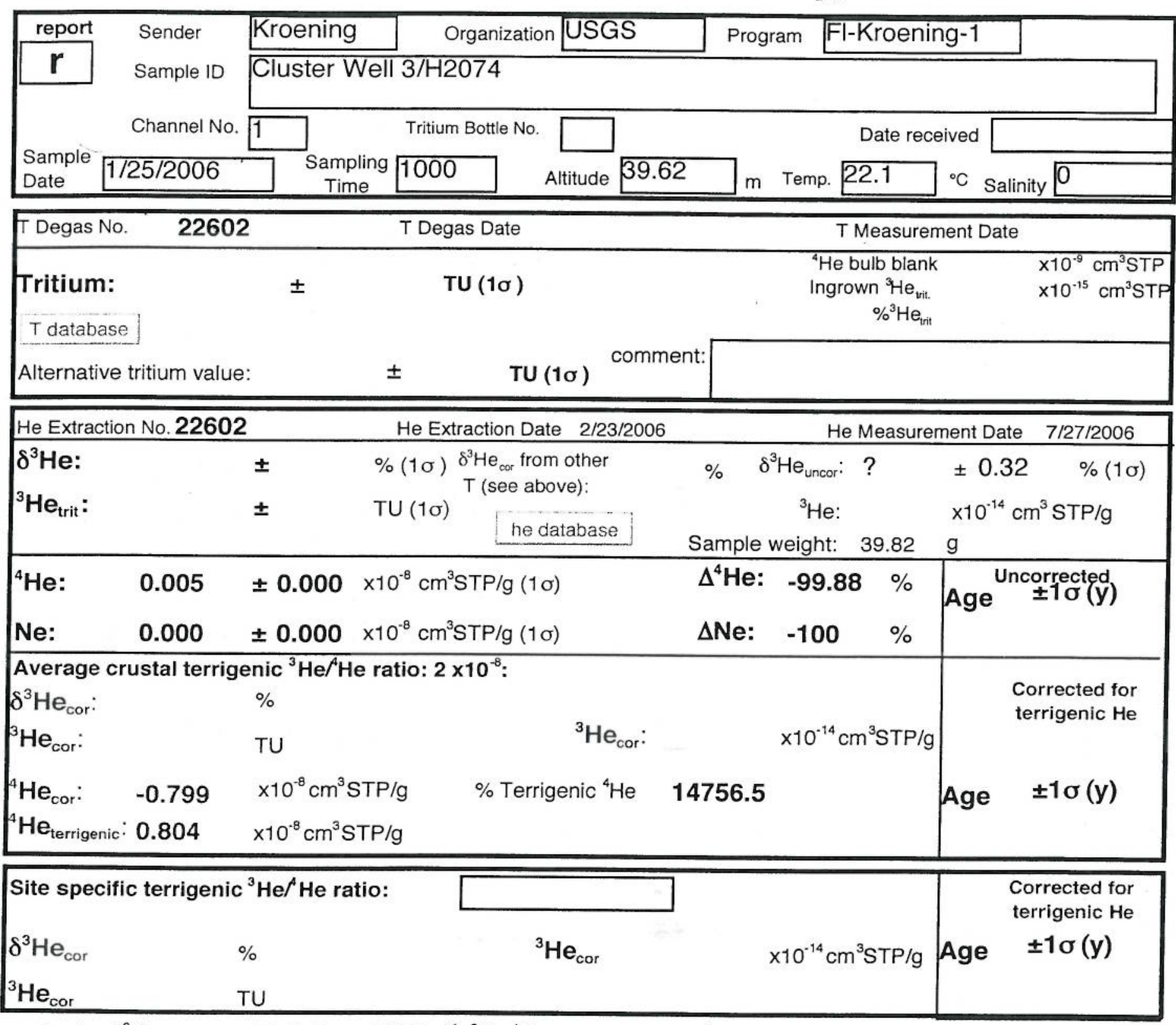

constants: $\delta^{3} \mathrm{He}_{\text {equilibrium }}:-1.8 \% ; \lambda_{3 \mathrm{H}}=.05577 \mathrm{yr} .^{-1} ;{ }^{3} \mathrm{He} / \mathrm{He}_{\text {atmos }}=1.384 \times 10^{-6}$

published
comments $\begin{aligned} & \text { High pressure at branch, Sample pumped due to either high concentration of dissolved gases or sampling problem. } \\ & \text { No more sample }\end{aligned}$

Comments: 


\section{Noble Gas Laboratory Lamont-Doherty Earth Observatory Columbia University, New York}

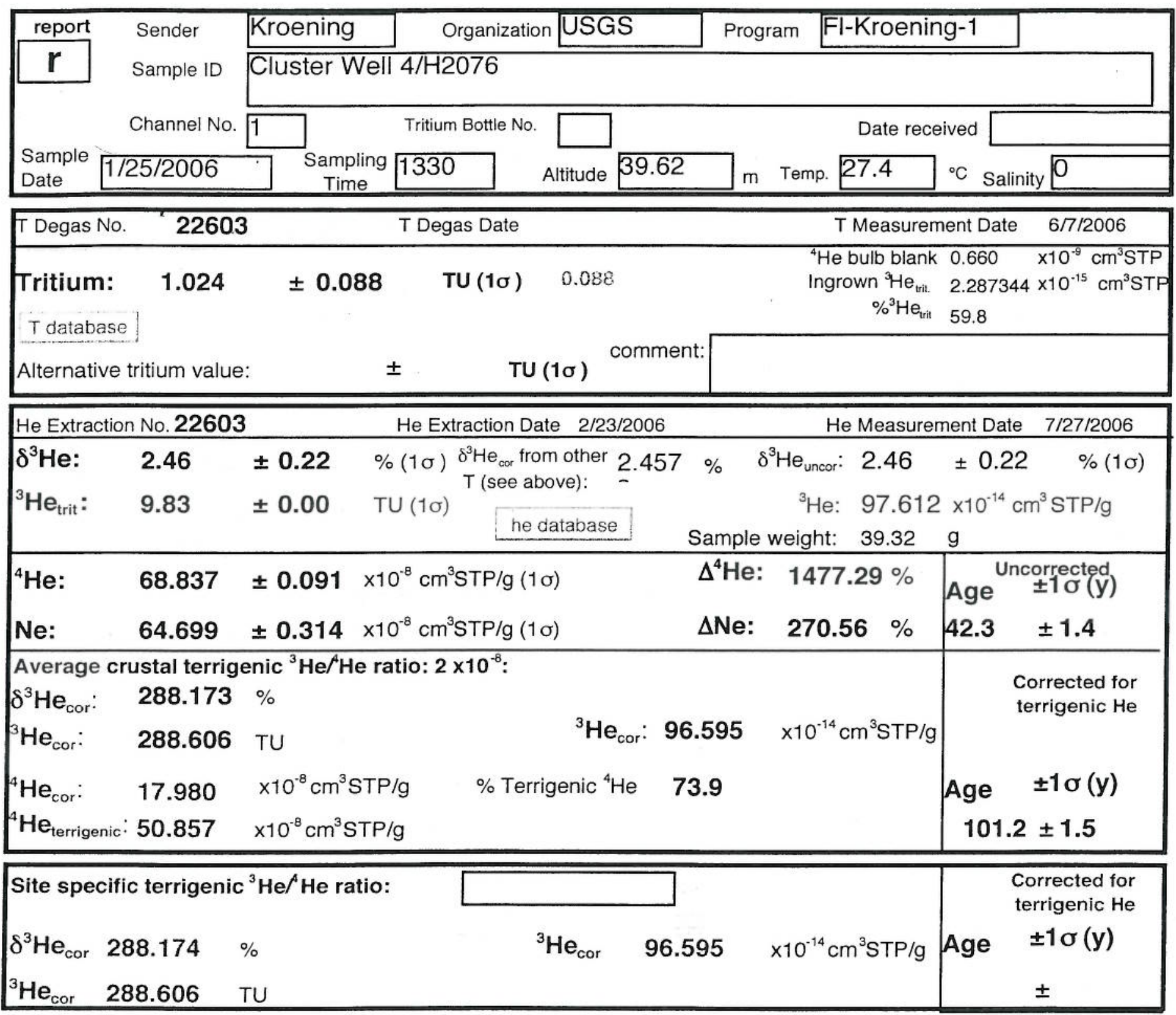

constants: $\delta^{3} \mathrm{He}_{\text {equilibrium: }}:-1.8 \% ; \lambda_{3 \mathrm{H}}=.05577 \mathrm{yr} .{ }^{-1} ;{ }^{3} \mathrm{He}^{4} \mathrm{He}_{\text {atmos. }}=1.384 \times 10^{-6}$

\begin{tabular}{|c|c|}
\hline & Terrigenic $\mathrm{He}$, use corrected age \\
\hline & $\begin{array}{l}\text { High } \Delta \mathrm{Ne} \text { and } \Delta \mathrm{Ne} \text { indicates possible air contamination } \\
\text { Tritium measurementlooks OK }\end{array}$ \\
\hline
\end{tabular}

Comments: 


\section{Noble Gas Laboratory Lamont-Doherty Earth Observatory Columbia University, New York}

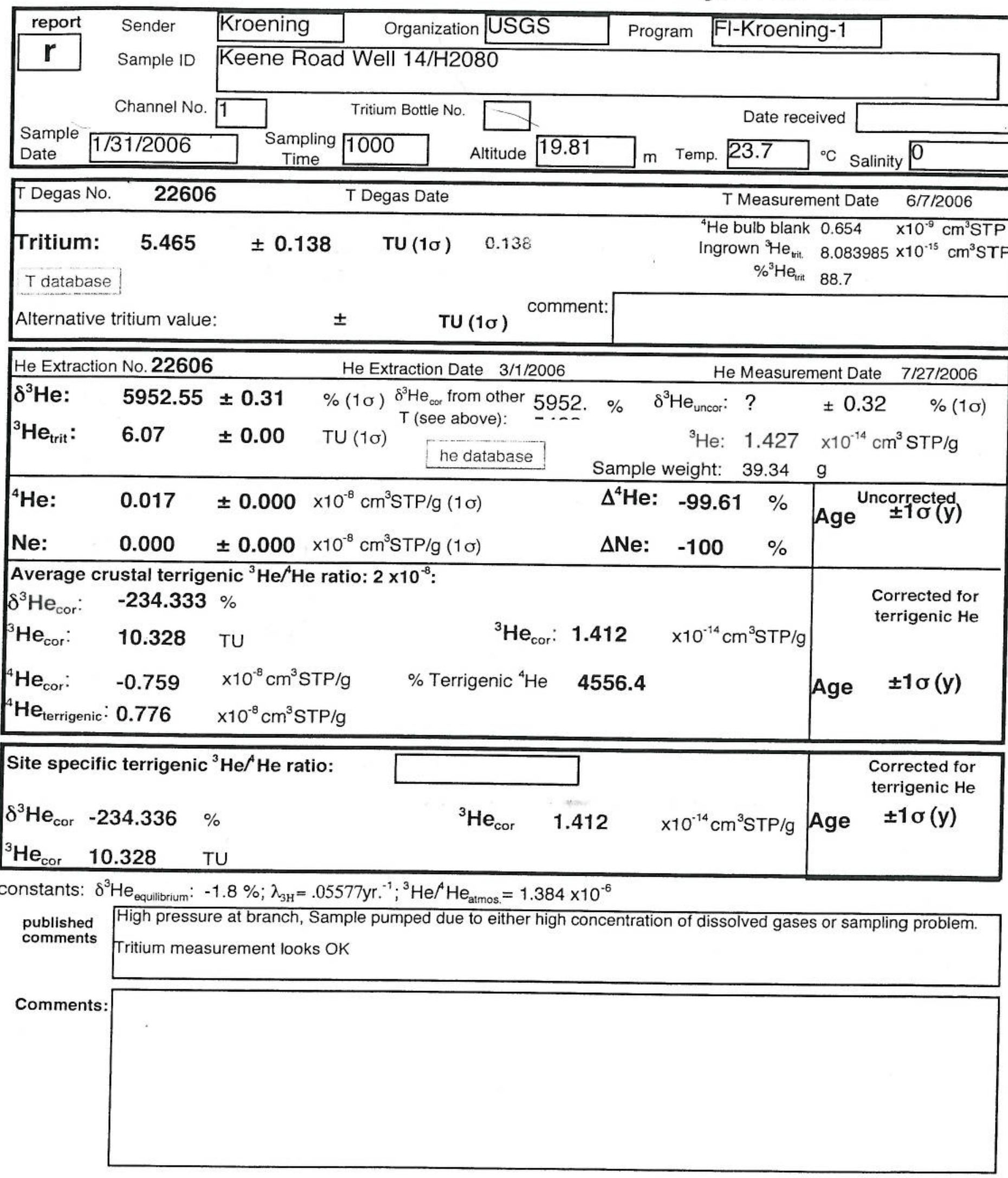




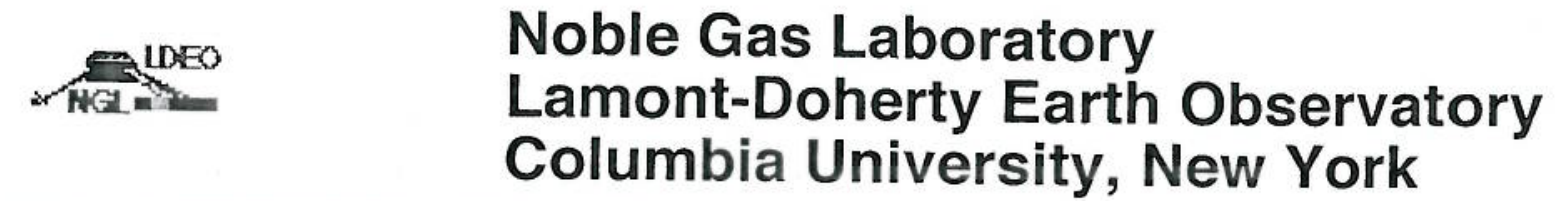

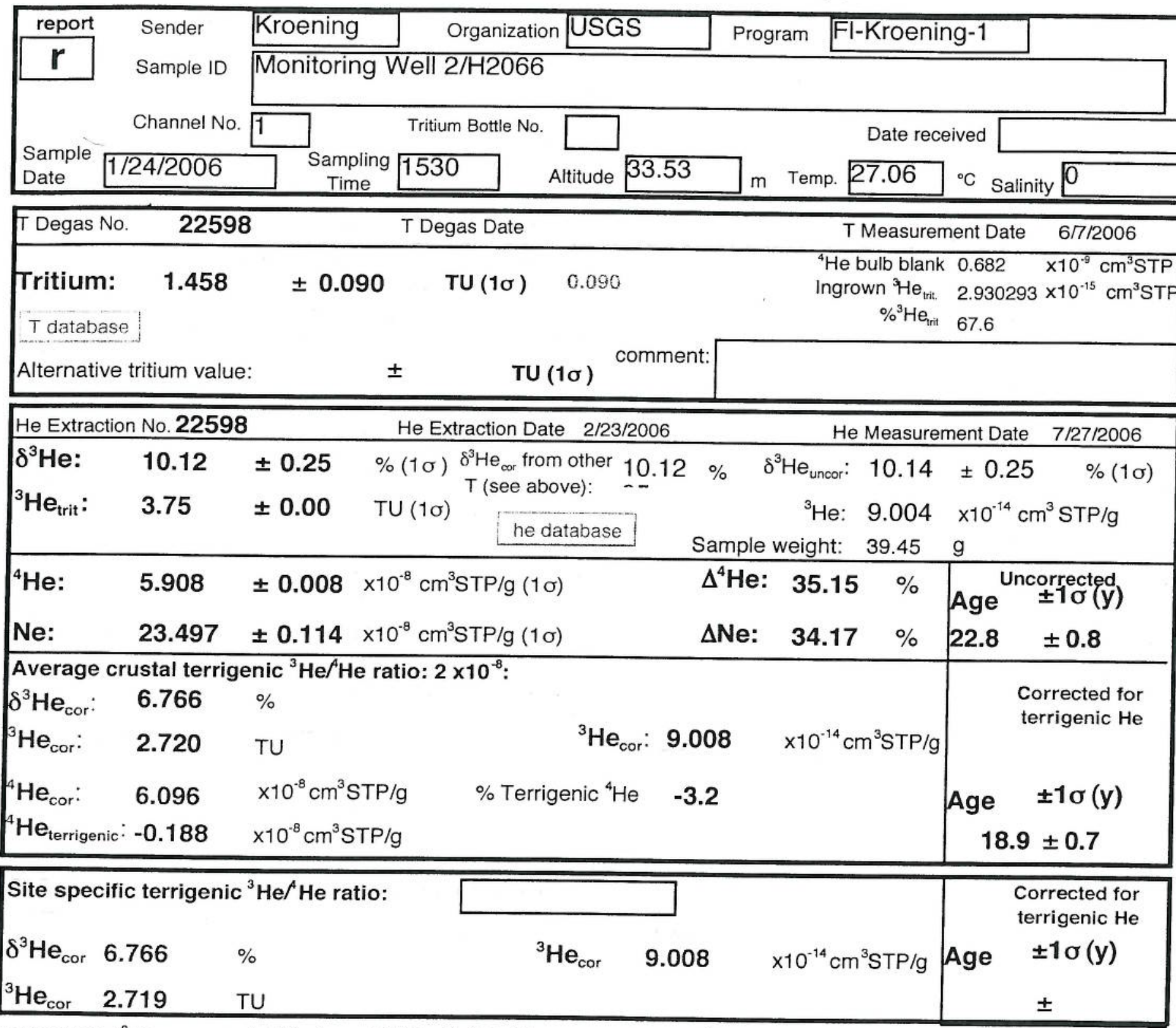

constants: $\delta^{3} \mathrm{He}_{\text {equilibrium: }}-1.8 \% ; \lambda_{3 \mathrm{H}}=.05577 \mathrm{yr} .{ }^{-1} ;{ }^{3} \mathrm{He}^{4} \mathrm{He}_{\text {atmos. }}=1.384 \times 10^{-6}$

published
comments

Comments: 


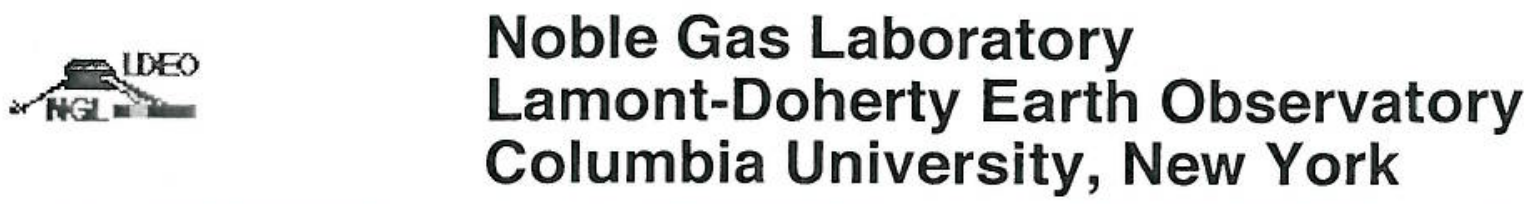

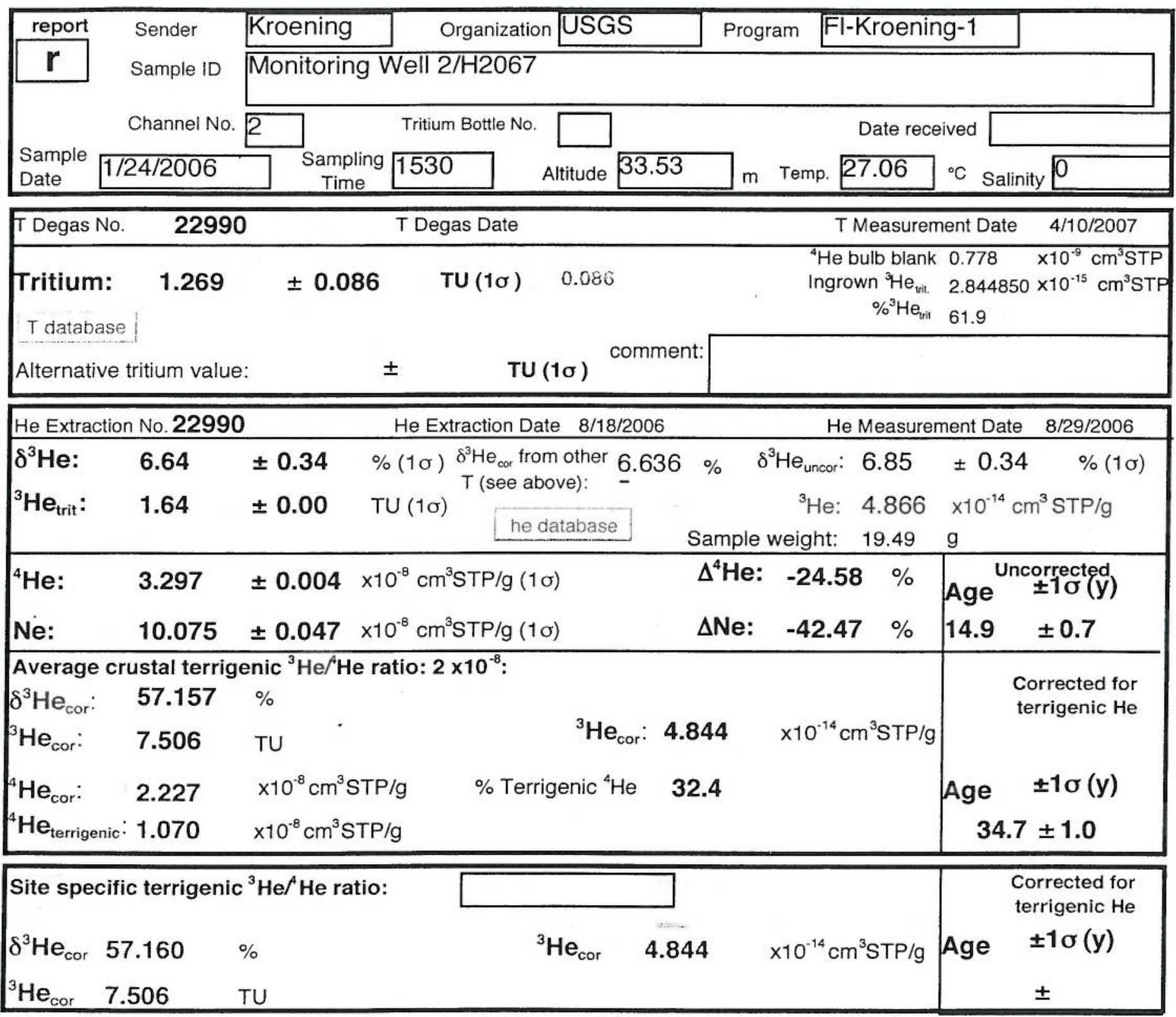

constants: $\delta^{3} \mathrm{He}_{\text {equilibrium }}:-1.8 \% ; \lambda_{3 \mathrm{H}}=.05577 \mathrm{yr}^{-1} ;{ }^{3} \mathrm{He}^{A} \mathrm{He}_{\text {atmos. }}=1.384 \times 10^{-6}$

\begin{tabular}{ll}
$\begin{array}{l}\text { published } \\
\text { comments }\end{array}$ & $\begin{array}{l}\text { Terrigenic He, use corrected age } \\
\text { Negative } \Delta \mathrm{He} \text { and } \Delta \mathrm{Ne} \text { indicates sample gas was stripped as the result of a sampling problem. Sample most likely } \\
\text { tractionated. Do notuse age. Tritium measurement looks OK }\end{array}$ \\
\hline
\end{tabular}




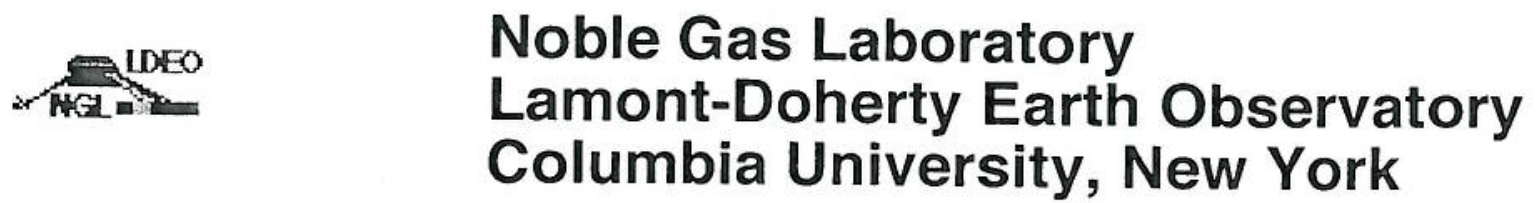

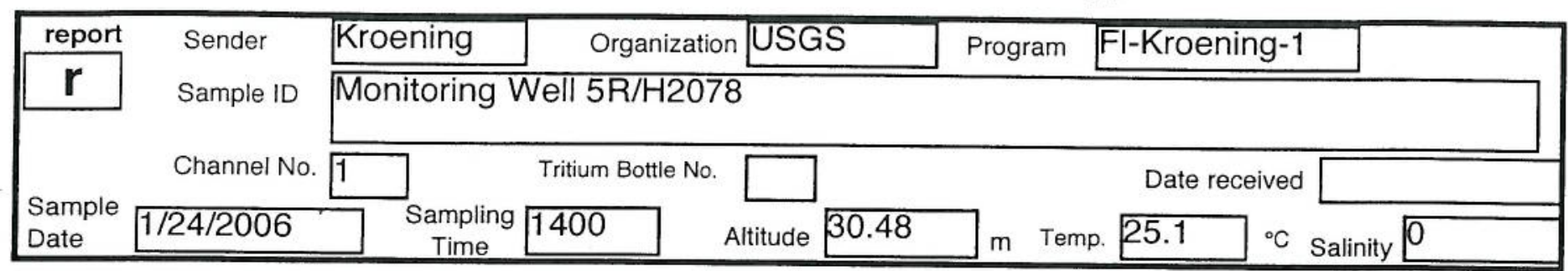

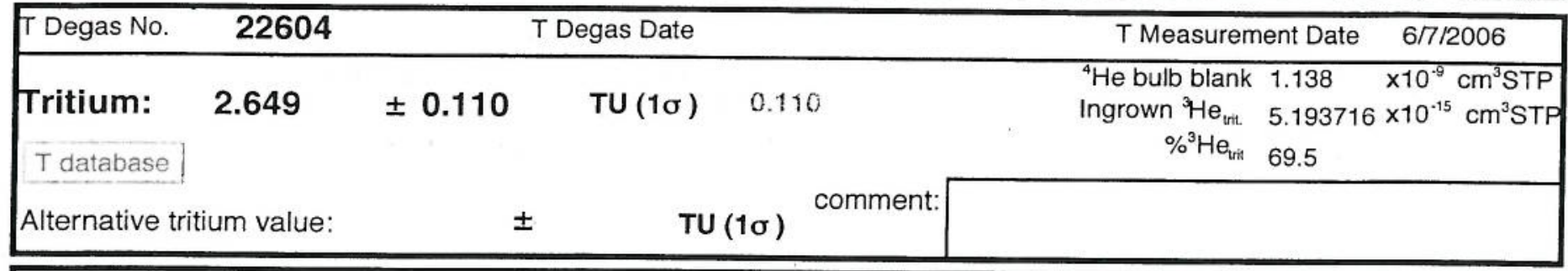

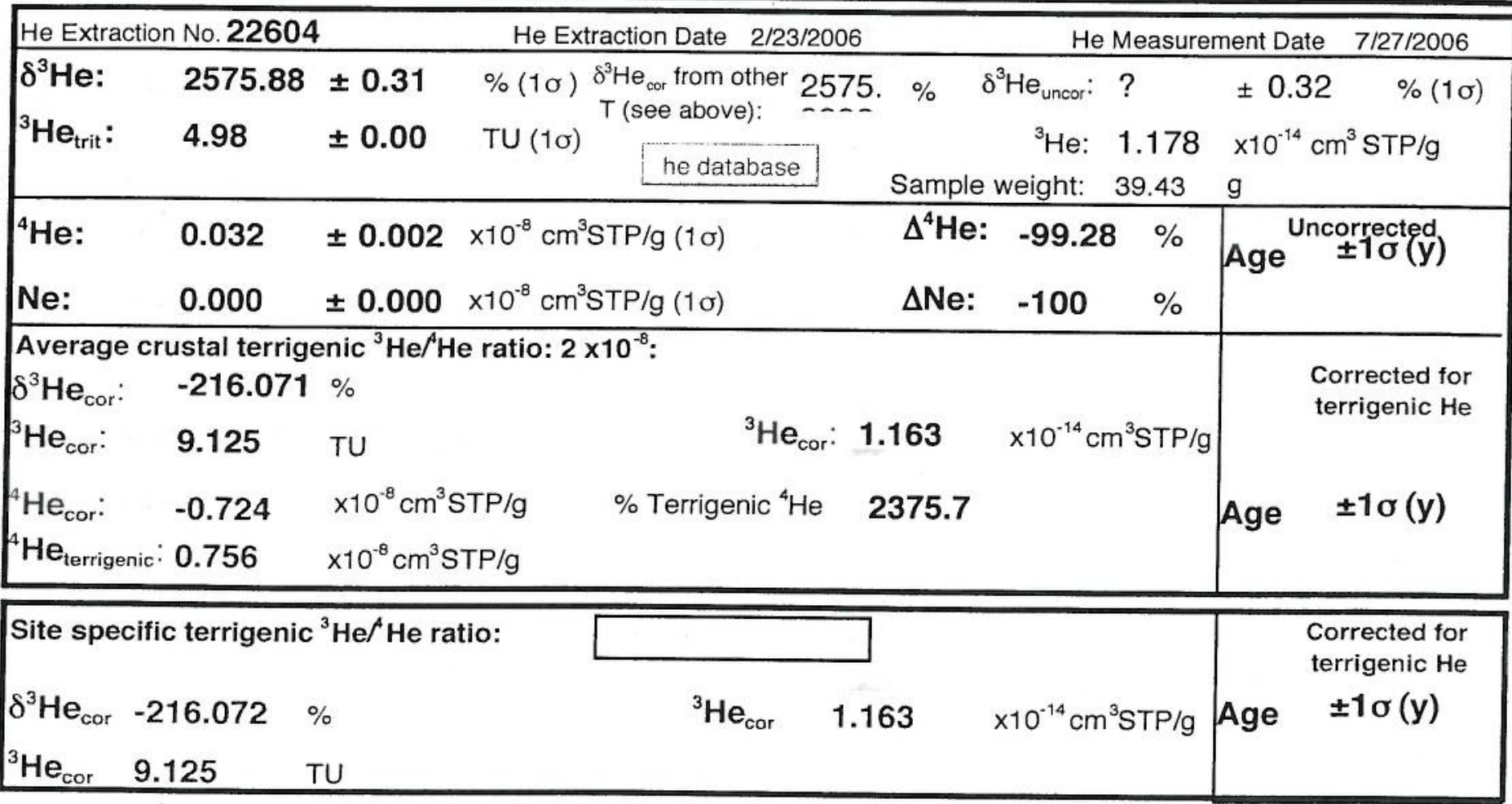

constants: $\delta^{3} \mathrm{He}_{\text {equilibrium }}:-1.8 \% ; \lambda_{3 \mathrm{H}}=.05577 \mathrm{yr} .{ }^{-1} ;{ }^{3} \mathrm{He}^{A} \mathrm{He}_{\text {atmos }}=1.384 \times 10^{-6}$

published
comments $\begin{aligned} & \text { High pressure at branch, Sample pumped due to either high concentration of dissolved gases or sampling problem. } \\ & \text { Tritium measurement looks OK, }{ }^{4} \mathrm{He} \text { bulb blank slightly elevated }\end{aligned}$

Comments: 


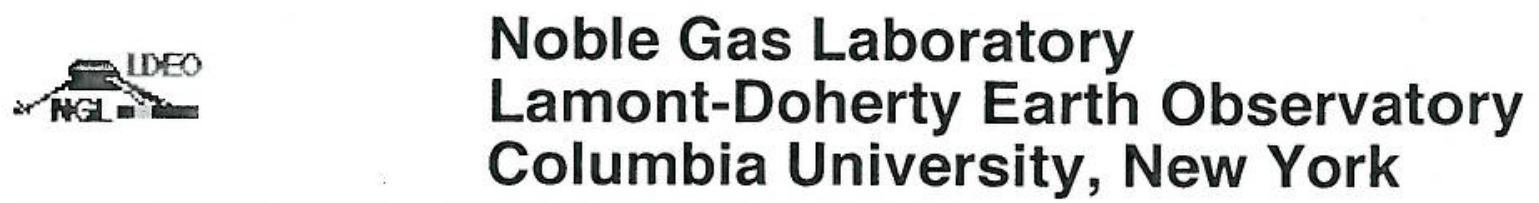

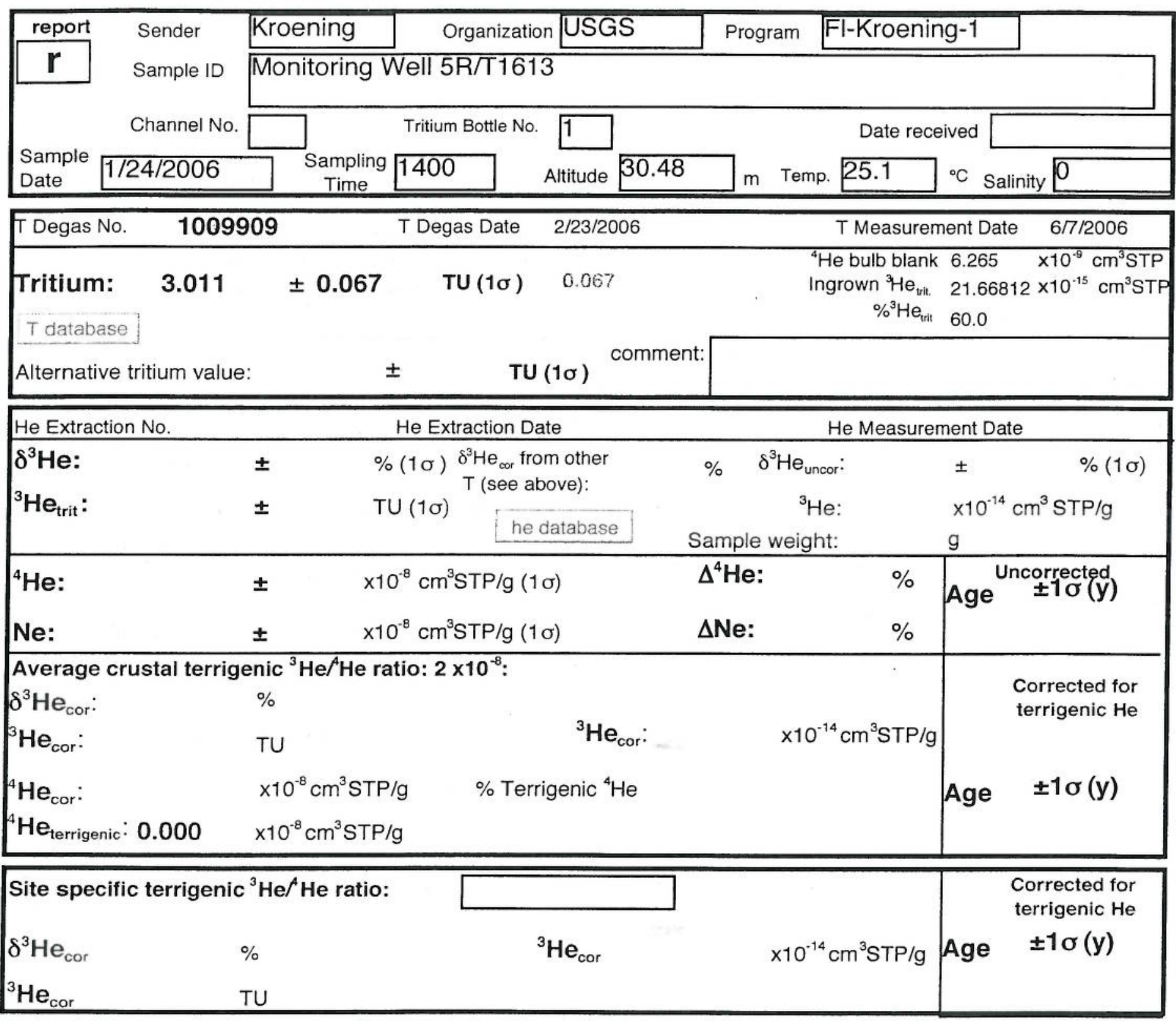

constants: $\delta^{3} \mathrm{He}_{\text {equilibrium }}:-1.8 \% ; \lambda_{3 \mathrm{H}}=.05577 \mathrm{yr}^{-1} ;{ }^{3} \mathrm{He} / \mathrm{He}_{\text {atmos. }}=1.384 \times 10^{-6}$

$\begin{array}{lll}\text { published } & \text { Tritium data from bottle sample } \\ \text { comments } & \text { High }{ }^{4} \mathrm{He} \text { bulb blank }\end{array}$

Comments: 


\section{Noble Gas Laboratory Lamont-Doherty Earth Observatory Columbia University, New York}

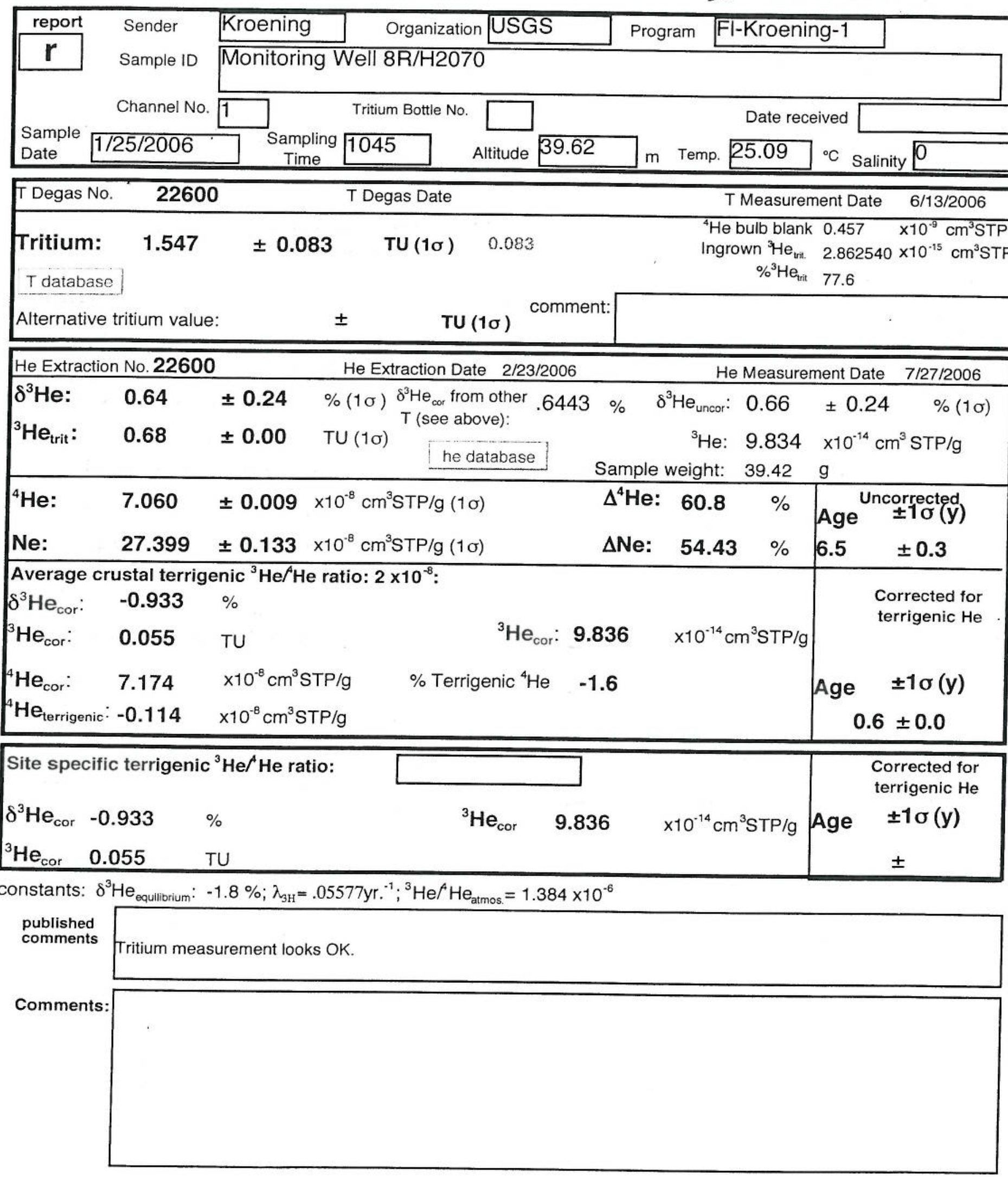


Noble Gas Laboratory

Lamont-Doherty Earth Observatory

Columbia University, New York

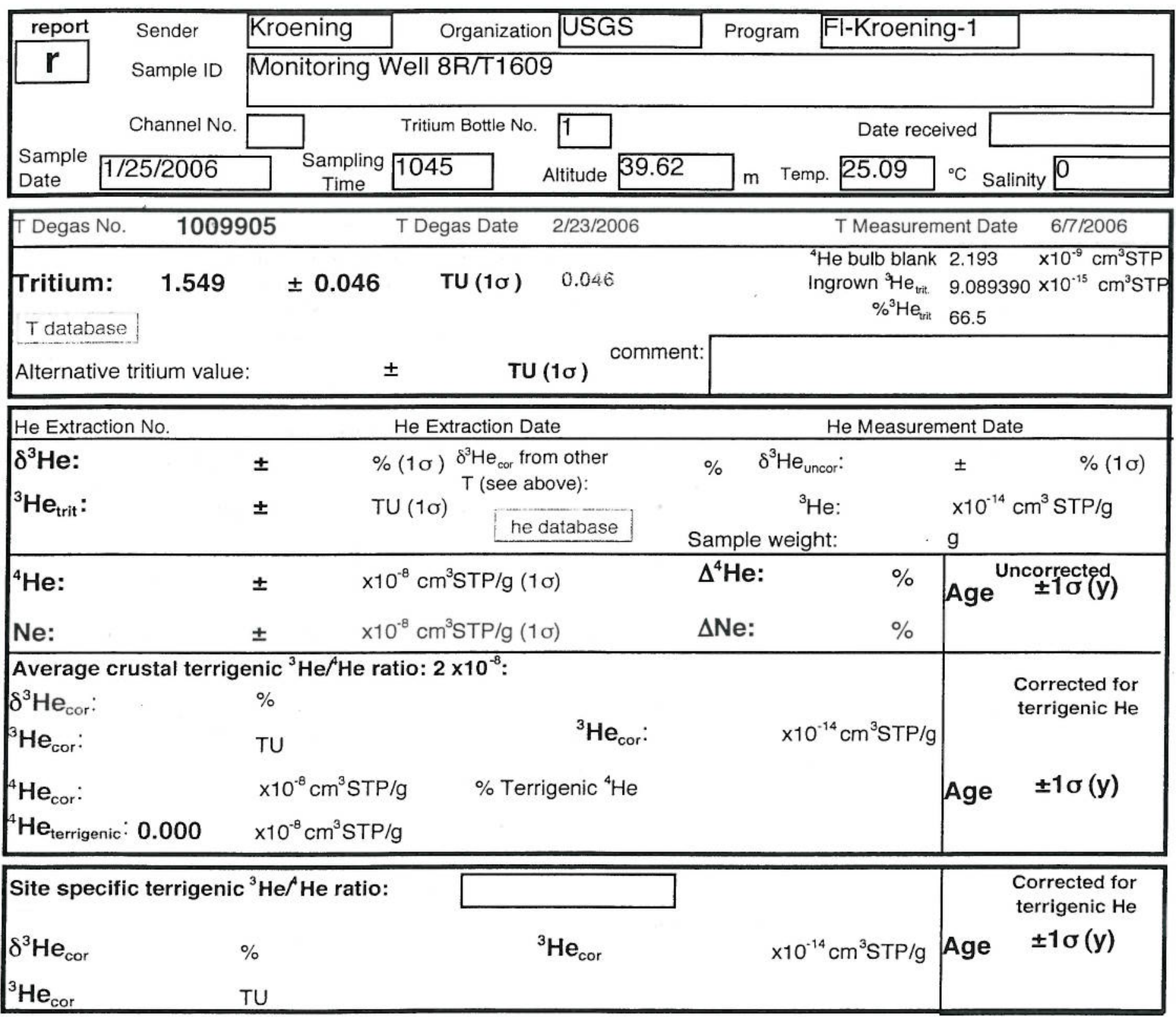

constants: $\delta^{3} \mathrm{He}_{\text {equilibrium }}:-1.8 \% ; \lambda_{3 \mathrm{H}}=.05577 \mathrm{yr} .{ }^{-1} ;{ }^{3} \mathrm{He} / \mathrm{He}^{A} \mathrm{etmos}=1.384 \times 10^{-6}$

published
comments $\begin{aligned} & \text { Tritium data from bottle sample } \\ & \text { Tritium measurement looks OK, }{ }^{4} \mathrm{He} \text { bulb blank elevated }\end{aligned}$

Comments: 


\section{Noble Gas Laboratory Lamont-Doherty Earth Observatory Columbia University, New York}

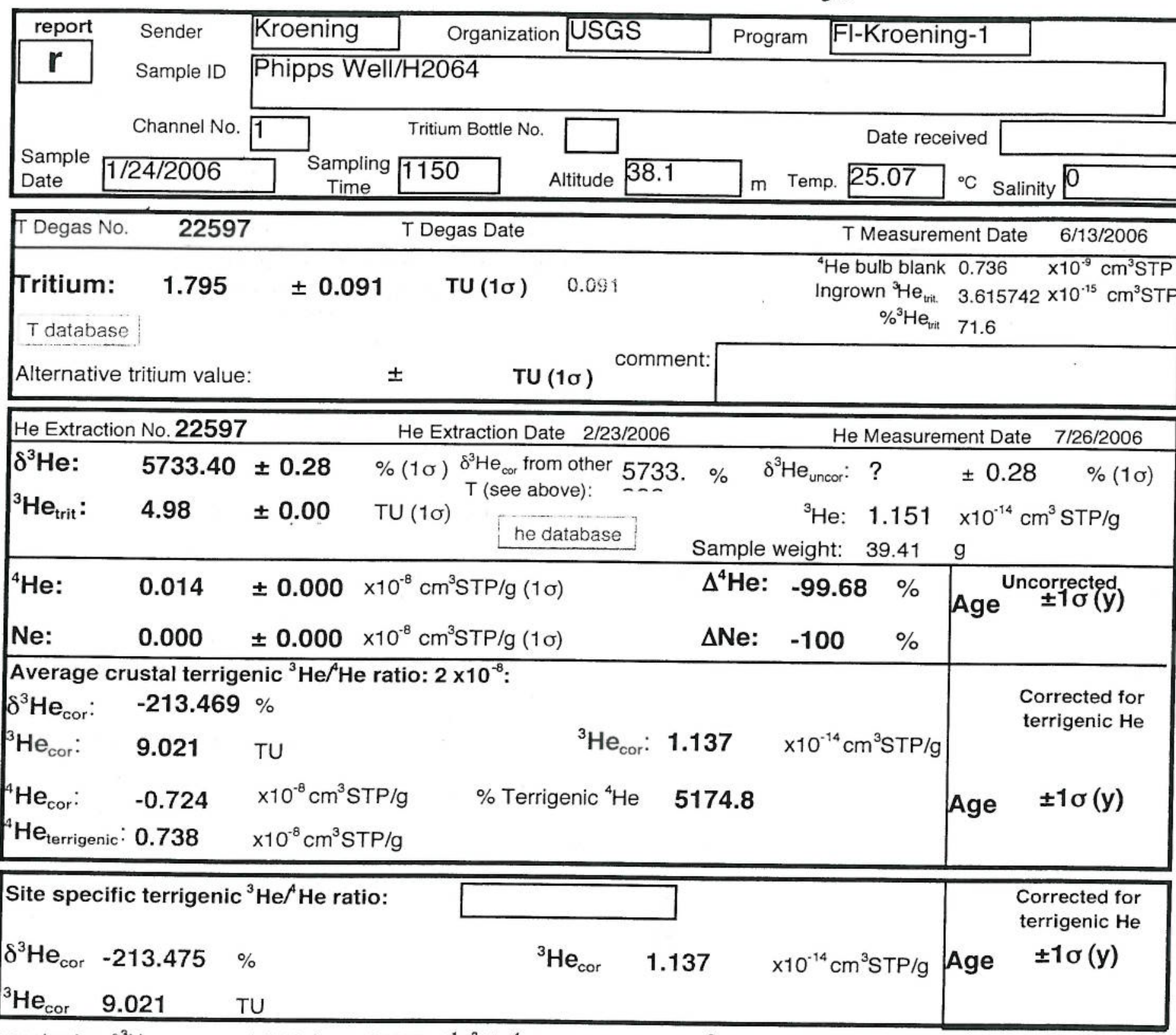

constants: $\delta^{3} \mathrm{He}_{\text {equilibrium: }}:-1.8 \% ; \lambda_{3 \mathrm{H}}=.05577 \mathrm{yr} .{ }^{-1} ;{ }^{3} \mathrm{He} /{ }^{4} \mathrm{He}_{\text {atmos. }}=1.384 \times 10^{-6}$

$\begin{aligned} & \text { published } \\ & \text { comments }\end{aligned} \begin{aligned} & \text { High pressure at branch, Sample pumped due to either high concentration of dissolved gases or sampling problem. } \\ & \text { Tritium measurement looks OK, }\end{aligned}$

Comments: 


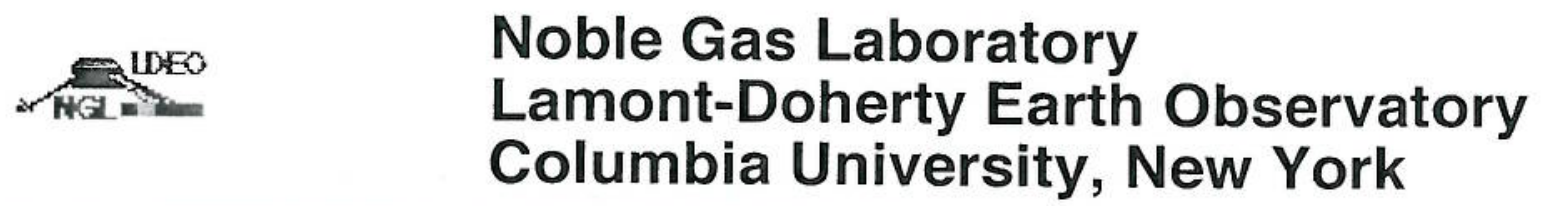

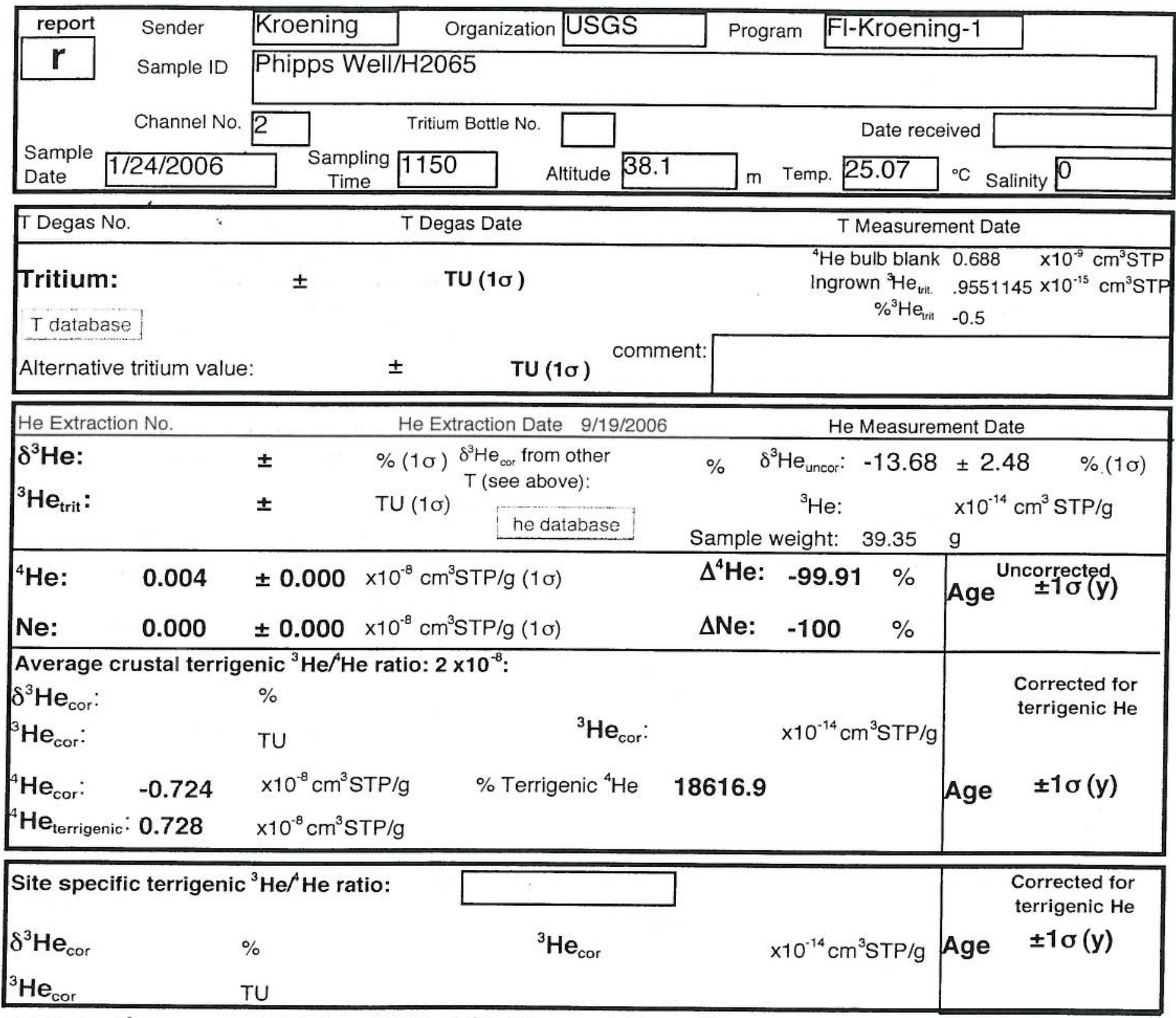

constants: $\delta^{3} \mathrm{He}_{\text {equilibrium }}:-1.8 \% ; \lambda_{3 \mathrm{H}}=.05577 \mathrm{yr} .{ }^{-1} ;{ }^{3} \mathrm{He}^{4} \mathrm{He}_{\text {atmos. }}=1.384 \times 10^{-6}$

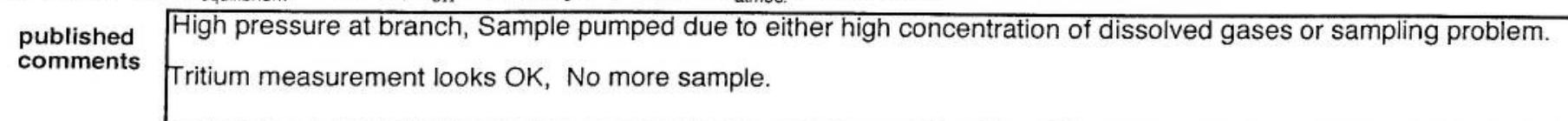

Comments: 


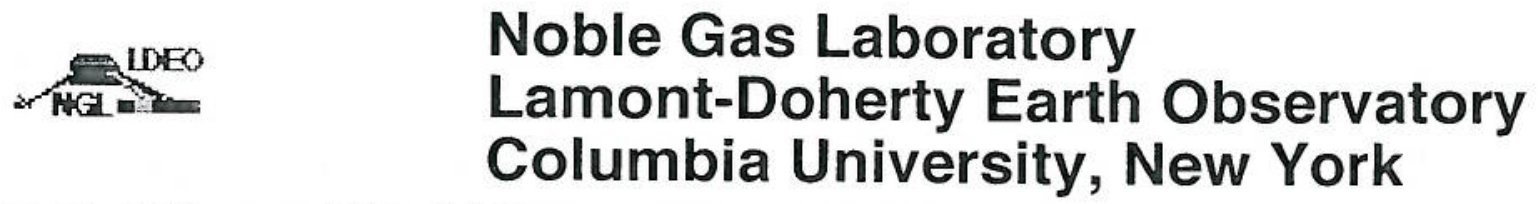

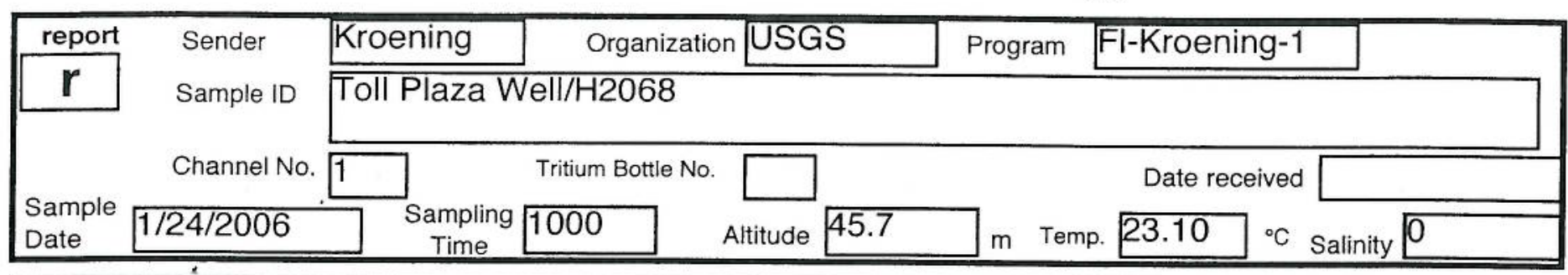

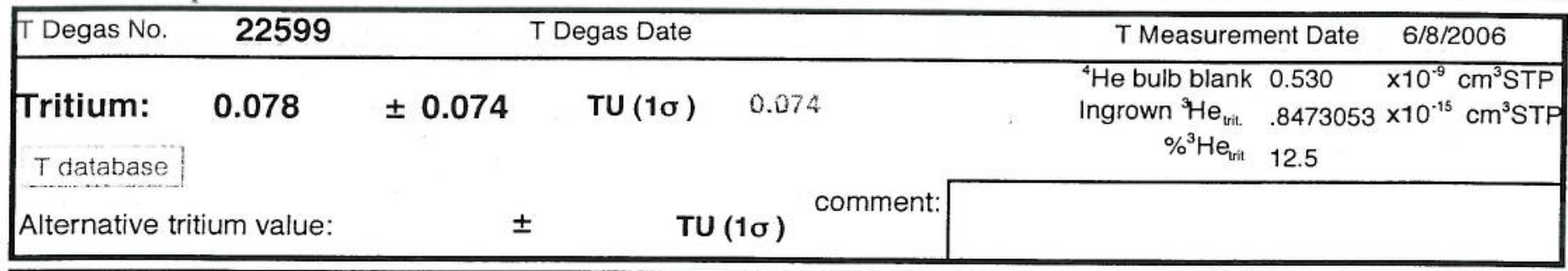

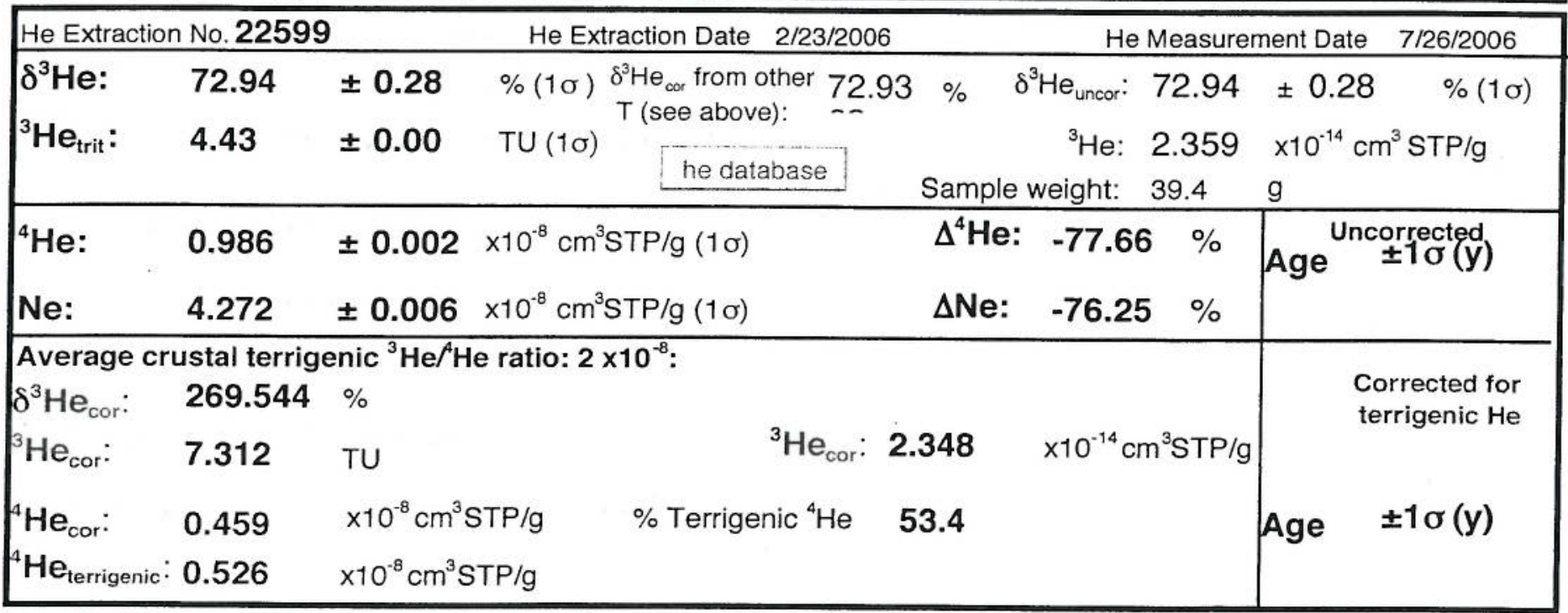

\begin{tabular}{|c|c|c|c|c|c|c|c|}
\hline \multicolumn{3}{|c|}{ Site specific terrigenic ${ }^{3} \mathrm{He} / \mathrm{He}$ ratio: } & \multirow[b]{2}{*}{${ }^{3} \mathrm{He}_{\text {cor }}$} & \multirow[b]{2}{*}{2.348} & \multirow{3}{*}{$\times 10^{-14} \mathrm{~cm}^{3} \mathrm{STP} / \mathrm{g}$} & \multirow{3}{*}{ Age } & \multirow{2}{*}{$\begin{array}{l}\text { Corrected for } \\
\text { terrigenic He } \\
\quad \pm 1 \sigma(y)\end{array}$} \\
\hline$\delta^{3} \mathrm{He}_{\text {cor }}$ & 269.548 & $\%$ & & & & & \\
\hline${ }^{3} \mathrm{He}_{\mathrm{cor}}$ & 7.312 & TU & & & & & \\
\hline
\end{tabular}

constants: $\delta^{3} \mathrm{He}_{\text {equilibrium }}:-1.8 \% ; \lambda_{3 \mathrm{H}}=.05577 \mathrm{yr} .{ }^{-1} ;{ }^{3} \mathrm{He} /{ }^{4} \mathrm{He}_{\text {atmos. }}=1.384 \times 10^{-5}$

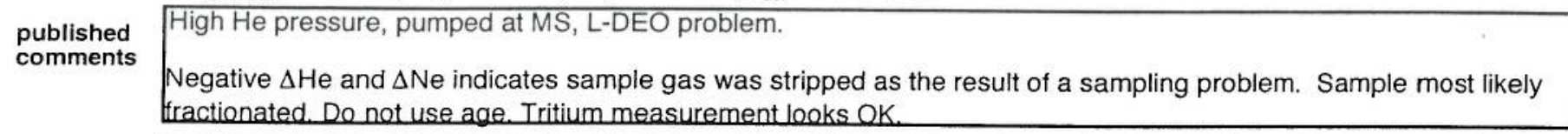

Comments: 